\title{
All Things to All Men: \\ Ethos in Cicero's Post-Ides Correspondence
}

by

Meg H. J. Galloway

A thesis submitted to the Victoria University of Wellington in fulfilment of the requirements for the degree of Master of Arts in Classical Studies

Victoria University of Wellington 
“people's real sentiments are so often concealed and their dispositions so complex."

Cicero, Epistulae ad Brutum 1.1.1 


\section{$\underline{\text { Acknowledgments }}$}

Thanks must first and foremost go to my supervisor, Professor Jeff Tatum. His advice and guidance throughout this process has been invaluable and, because of him, I have learnt more in this last year than I ever thought possible. And, were it not for CLAS105, his introduction to Roman History and society which I took as a first year, I doubt this thesis would even exist.

To the revolving residents of OK520, the officemates with whom I toiled, thank you for the bellylaughs. You all made the long days bearable and I always enjoyed our Friday crossword- even if we were pretty terrible at it. Thanks especially to Matthew for showing me dumb YouTube videos when neither of us felt like working.

My friends and flatmates, I appreciate you reminding me that there exists a world outside of university. I am grateful to Sinead in particular for always knowing when, and how, to cheer me up.

Finally, I am most indebted to my family: my mum Caroline, my stepdad Chris, my dad Alan, and my stepmum Tania. Your love, understanding, and support has carried me through my university years and without it, writing this Master's thesis would have been impossible. 


\section{Contents}

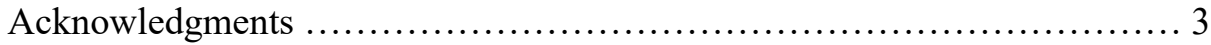

Contents ................................................................... 4

Introduction

Ethos and the Ides of March.............................................. 5

Chapter One

Phronesis: Cicero as Nestor ........................................... 25

Chapter Two

Eunoia: Cicero as Amicus

Chapter Three

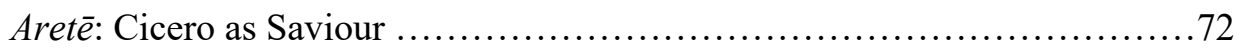

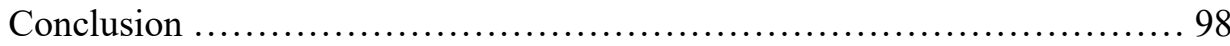

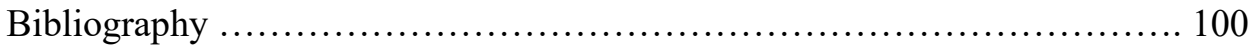




\section{Introduction:}

\section{Ethos and the Ides of March}

When the Liberators assassinated Caesar on the Ides of March 44 BC, they had hoped their act would restore libertas to the decaying res publica. Instead came intense conflict as dominant individuals sought to fill the power vacuum left behind and establish their own influence over the Roman world. Importantly, the mass exodus of prominent statesmen from the city following Caesar's funeral saw correspondence become the "crucial fabric of political life" between 44 and 43 BC. ${ }^{1}$ The elite epistolary habit was electrified during this time and letters represented an essential mechanism for negotiation, persuasion, and the performance of self. Indeed, the rhetorical dimensions of Latin epistolography have long been recognized. ${ }^{2}$ Like the orator, the correspondent has a rhetorical objective and will manipulate his epistolary persona in order to achieve it. This is especially true of Cicero, whose letters offer an unprecedented window into "elite motivation" and manipulation in this period of intense crisis. ${ }^{3}$ And crisis it was. Having dedicated his entire career to the welfare of the state, when Antony posed a formidable threat to its very existence, the now elderly orator sought once more to take on the mantle of leadership and unite the Senate against him under a single republican cause. Only this time, Cicero did not possess the necessary magisterial authority to direct affairs and his influence over the Senatewhich he had once described as his "right hand"- was fragile at best (Fam. 11.14.1). ${ }^{4}$ Now also faced with the challenge of physical distance, it was largely upon his correspondence that the statesman had to rely for political manoeuvring and persuasion. Cicero's letters, then, played a critical role in his self-fashioning of fresh authority following Caesar's assassination.

In this thesis, I illuminate the nuances of Cicero's post-Ides self-fashioning by assessing his letters through the lens of ethos. First conceived by Aristotle in his Rhetoric, ethos was

\footnotetext{
${ }^{1}$ Butler (2002) 105.

${ }^{2}$ Fundamental works on epistolary rhetoric and persuasion include May (1988); Hutchinson (1998); Meyer (2000); Dugan (2005); Morello \& Morrison (2007); Hall (2009); White (2010); Wilcox (2012); Bernard (2013); Gildenhard (2018).

${ }^{3}$ White (2010) 164.

${ }^{4}$ All translations of Cicero's letters in this thesis are taken from D. R. Shackleton Bailey's Loeb editions; see Bibliography for full entry.
} 
defined broadly as 'character' or 'persona', and denoted the way in which a rhetor manipulated the audience by way of his own self-fashioning (Arist. Rh. 1.1356a3-13). The philosopher further proposed that ethos consisted of three parts, phronesis ('practical wisdom' or 'prudence'), eunoia ('goodwill' or 'benevolence'), and aretē , ('excellence' or 'virtue'), each of which an orator must employ to fashion for himself a credible persona (Arist. Rh. 2.1378a6). Cicero, influenced by his own familiarity with the Peripatetic tradition, likewise conceived of ethos in the form of conciliare (Cic. De or. 2.178, 182). However, owing to the Roman veneration of mos maiorum and a firm belief that character was the "diachronic development of one's dignitas, auctoritas, and future gloria", his notion of rhetorical self-fashioning was inherently broader. ${ }^{5}$ Nonetheless, both authors concur in their identification of the orator's character as essential to the rhetorical success of a speech. When applied to the correspondence, then, this rhetorical framework reveals a series of calculated epistolary personae employed by Cicero to help cultivate fresh authority as Rome's post-Ides helmsman.

Chapter One takes phronesis as its lens to assess how Cicero draws on ideas of practical wisdom, good sense, and prudence to fashion himself as a new Nestor. Rather than root his authority in political or military prestige, the elderly statesman establishes that he is an experienced and sagacious figure to whom both Liberators and Caesarians alike could turn for counsel. In doing so, Cicero hoped to indirectly guide the affairs of the state in an advisory role and maintain an image of learned authority while doing so.

Next, Chapter Two examines how Cicero evokes eunoia-and its Latin equivalent benevolentia - to cast himself as amicus. Unable to steer the Republic on his own, the statesman works diligently to forge alliances by cultivating goodwill, establishing commonality, and offering his support. His correspondence with Plancus is especially useful in unpacking this unique facet of ethos. Cicero is at great pains to recruit the young Caesarian to his cause and

\footnotetext{
${ }^{5}$ Samponaro (2007) 14.
} 
tailors his epistolary persona to generate between them a strong sense of mutual benevolence which he in turn manipulates for his own cause.

Finally, Chapter Three employs aretē and its parallel virtus to consider Cicero's selffashioning as the saviour of the res publica. These ideals are closely tied to the winning of renown and glory through noble service to the state, be it as a warrior or politician. In his correspondence, Cicero takes measures to present the preservation of the state and its libertas as his own cosmic purpose. He emphasizes his heroism in the face of Rome's greatest threat-Antony-and ultimately binds the welfare of the Republic tightly to his carefully manufactured persona. ${ }^{6}$ In doing so, he sought to secure authority as the helmsman of the Senate. Ultimately, by examining the letters with ethos as a lens, I reveal that his post-Ides correspondence is saturated with instances of calculated persona creation and demonstrate the significant-often underappreciated-role that Cicero's correspondence played in his self-fashioning of authority following Caesar's assassination.

\section{Aristotelian Ethos}

Though Aristotelian ethos is a rhetorical concept that has long been subject to scholarly treatment, it will be useful nonetheless to offer here a brief survey of the basic principles discussed in his Rhetoric. ${ }^{7}$ It is in book one of the treatise that Aristotle first introduces the pisteis (literally, proofs): these are the means of persuasion which a rhetorician, if he is to be successful, ought to employ (Arist. Rh. 1.1355b2). Defined as either artistic (entechnic) or inartistic (atechnic) proofs, Aristotle draws a clear distinction between the various means of persuasion. An inartistic proof is evidence that is applied rather than invented by the speaker (Arist. Rh. 1.1355b2). ${ }^{8}$ By contrast, an artistic proof is one that is artificially constructed by the orator within the confines of his own speech (Arist. Rh. 1.1355b2). Famously, there are three entechnic modes of persuasion that occur at the time of delivery. The first, ethos, is dependent on the character of the speaker, the second,

\footnotetext{
${ }^{6}$ Brunt (1986) 16.

${ }^{7}$ On Aristotle's theory of ethos and the pisteis in general see Solmsen (1941); Grimaldi (1980); Kennedy (1963); Fortenbaugh (1975) and (1992); Wisse (1989).

${ }^{8}$ Fortenbaugh (1992) 208; Wisse (1989) 15.
} 
pathos, is concerned with manipulating the audience's frame of mind, and finally, logos looks to the speech itself and the persuasive power of reasoned argumentation (Arist. $R h .1 .1356 \mathrm{a} 3-7) .{ }^{9}$ To Aristotle, ethos was the most effective means of persuasion (Arist. Rh. 1.1356a3-13). Because it is in the nature of rhetoric to reason by way of probability, great significance is placed on the credibility of the orator; an audience will more readily trust, and therefore be influenced by, a speaker whose character they perceive as worthy of belief (Arist. $R h .1 .1356 a 3-13$ ). ${ }^{10}$ In the Rhetoric, to be worthy a rhetorician must demonstrate that he possesses sound intellectual and moral qualities which Aristotle has efficiently arranged into three categories: phronesis, eunoia, and $\operatorname{arete}($ Arist. $R h .2 .1378 \mathrm{a} 6) .{ }^{11}$

\section{Phronesis:}

Typically translated as 'good sense', 'practical wisdom', or 'prudence', phronesis is defined by C.C.W. Taylor as "comprising a true conception of the good life and the deliberative excellence necessary to realise that conception in practice via choice". ${ }^{12}$ In essence, it is an intellectual virtue concerned with rational decision making, one which Aristotle insists is realised in two stages. ${ }^{13}$ First, a man demonstrates phronesis by undergoing a reasoned process of deliberation. When confronted with an issue, he must investigate the situation, take account of contextual factors, and calculate how best to achieve his objectives (Arist. Eth. Nic. $6.1142 \mathrm{~b} 1-30) .{ }^{14}$ Second, as a result of this deliberative process, he must arrive at a sensible decision and make a choice which is "good" for himself and his fellow human beings (Arist. Eth. Nic. 6.1140a24-30). Indeed, this decision must promote eudaimonia, the highest good that mankind is capable of attaining. ${ }^{15}$ Here, Pericles serves as Aristotle's paradigm. Throughout his career, the statesman demonstrated that he could successfully assess the circumstances, rationally discern what was right for himself and the Athenians, and eloquently express this choice in an oration (Arist. Eth. Nic. 6.1140b5). What

\footnotetext{
${ }^{9}$ Cherry (1988) 253. For more on pathos in Aristotle see Wisse (1989) 65-76; Fortenbaugh (1975).

10 Sattler (1947) 57-8; Cherry (1988) 253.

${ }^{11}$ Sattler (1947) 57-8; Wisse (1989) 29.

12 Taylor (2005) 137; see also Cherry (1988) 253.

${ }^{13}$ Reeve (1995) 67-98.

${ }^{14}$ Reeve (1995) 97.

${ }^{15}$ Ibid.
} 
is more, Pericles was sufficiently mature. Because phronesis is concerned with particular knowledge, the kind which can only be derived from experiences that come with age, young men cannot be said to possess practical wisdom or good sense (Arist. Eth. Nic. 6.1142a10-15). To cultivate wisdom was to dedicate years of one's life to the study of philosophical virtues, all the while practicing self-control, behaving correctly, and maintaining a "judicious absorption of experience". ${ }^{16}$ Phronesis, therefore, is an intellectual virtue which signals not only skilled judgement, but excellence of character. ${ }^{17}$ It is for this reason that Aristotle considers it one of the three fundamental components of ethos. Without deliberative excellence, the rhetor loses his ability to reason and will therefore form incorrect opinions (Arist. $R h .1378 \mathrm{a} 6-7$ ). In turn, he becomes an unreliable advisor and is no longer deemed worthy of the audience's trust. ${ }^{18}$ Ultimately, phronesis is "that sagacity which enables a man to find fit means to an end" ${ }^{19}$ It defines the process by which a rhetor draws on his physical and moral seniority in order to establish himself as an excellent deliberator, decision maker, and mentor.

\section{Eunoia:}

Conventionally defined as goodwill or benevolence, eunoia is perhaps the most unique of the three categories of ethos because it concerns not only the character of the rhetor, but that of his audience..$^{20}$ In the first instance, Aristotle locates this concept of benevolence within the broader context of philia. He defines eunoia as reciprocal goodwill, a kind of well-wishing that must occur mutually between two people (Arist. Eth. Nic. 9.1167a9-16). Should both parties also desire what is best for each other, and "share the same ideas of good and evil, and love and hate", then this mutual goodwill, according to Aristotle, will become genuine friendship (Arist. Rh. 2.1381a4). ${ }^{21}$ As he understands it, the highest form of philia occurs when two people, having sought each

\footnotetext{
${ }^{16}$ Cokayne (2003) 91. For a discussion of the correlation between experience and wisdom in the ancient world see Cokayne (2003) 91-111; for a general survey of the cultural and social significance of old age in Greece and Rome see Parkin (2002).

${ }^{17}$ Reeve (1995) 84-91.

${ }^{18}$ Sattler (1947) 59; Wisse (1989) 30.

${ }^{19}$ Sattler (1947) 58.

${ }^{20}$ Schütrumpf (2007) 39; Hourcade (2018) 87.

${ }^{21}$ Translation by Freese (2020). For Aristotle's conception of goodwill as a principal of friendship/philia see Eth. Nic. 9.1167a9-16.
} 
other's company on the basis of common morality, are intent on advancing one another's cause out of mutual appreciation, as opposed to other alternative self-serving motives. ${ }^{22}$ Eunoia, then, takes on a more complex meaning. Beyond goodwill, it is deeply rooted in the conception of friendship and represents reciprocal "approval, sympathy, and readiness to help". ${ }^{23}$ It is this element of exchange which makes eunoia a useful tool in the rhetor's own construction of ethos. Essentially, he can secure the trust and support of his audience by first demonstrating that he trusts and will support them.

Though a seemingly simple task, establishing eunoia is a complex process. To arouse feelings of goodwill is to actively cause emotions in the audience, a feat the orator accomplishes by relying on a range of sentiments that are allied with philia. ${ }^{24}$ In the first instance, he needs to demonstrate that he identifies with his listeners and is effectively on their side. Achieving this, as Roger Cherry notes, involves "assessing the characteristics of an audience and constructing the discourse so as to portray oneself as embodying those characteristics". ${ }^{25}$ The successful rhetor is one who recognizes his audience's psyche and uses it to fashion is own self-image; he likes what they like, hates what they hate, and possesses qualities they revere (Arist. $R h .1 .1365 \mathrm{~b} 41-3$ ) ${ }^{26}$ What is more, because eunoia is reciprocal goodwill, one must first characterise himself as benevolent towards, and supportive of, the audience in order to elicit same in return. Here, as William Sattler notes, the successful rhetor is the one who a) recognizes the good in his audience, b) praises these good qualities, c) takes his audience seriously, and d) is willing to help them. ${ }^{27}$ Should the orator construct a persona that exhibits these qualities, the addressees will respond in kind and, ultimately, eunoia is established. Without goodwill, Aristotle claims that the orator will fail to give the best advice, even though he knows what it is (Arist. Rh. 2.1378a7). Thus, when demonstrated successfully, eunoia works to construct a credible, persuasive persona.

\footnotetext{
22 Brewer (2005) 723-4.

${ }^{23}$ Romilly (1958) 92.

${ }^{24}$ Garver (1994) 110-1; Schütrumpf (2007) 39.

${ }^{25}$ Cherry (1988) 225.

${ }^{26}$ Sattler (1947) 59; Schütrumpf (2007) 39.

${ }^{27}$ Sattler (1947) 59.
} 
Aretē:

Finally, arete in its simplest form is moral virtue or excellence and, according Arthur Adkins, is one of the "most powerful words of commendation used of a man both in Homer and in later Greek" ${ }^{28}$ In its earliest Homeric context, aretē was acquired by those who exhibited the inherent goodness, courage, and dexterity of a warrior. Achilles is the most oft-cited example. The hero of the Iliad possessed outstanding physical strength and a fearlessness that was second to none. ${ }^{29}$ More importantly however, he was destined to die gloriously in battle. This emphasis on heroic death rests upon the belief that arete is fundamentally an "external phenomenon", one which relies on outside "reception and acknowledgement for its instantiation" ${ }^{30}$ Only certain public acts were considered worthy of honour and to die on the battlefield in service to one's country was among them. ${ }^{31}$ Aristotle reflects this sentiment in his own conception of virtue when he writes "aretē, it would seem, is a faculty of providing and preserving good things (...) which a man does for the sake of his country, while neglecting his own interests" (Arist. Rh. 1.1366b3-17). ${ }^{32}$ When he is courageous, just, and uses reason in order to achieve what is good for his community, then a man can be said to possess aretē. In this sense, Terence Ball suggests that a more appropriate translation of aretē is "role-related specific excellence". ${ }^{33}$ Such a definition encapsulates the idea that arete is ultimately that set of qualities which allows an individual to fulfil his noble, perhaps even fated, purpose. In the realm of rhetoric, an orator who does not demonstrate this moral virtue will fail to persuade his audience (Arist. Rh. 2.1378a6-7). Possession of aretē not only illustrates that he is dignified and accomplished (and should therefore be trusted), but that the cause for which he speaks will serve the greater good.

\footnotetext{
${ }^{28}$ Adkins (1960) 30.

${ }^{29}$ Achilles is described as 'brilliant' (Il. 1.8), the 'best of the Achaeans' (Il. 1.108), 'swift-footed' (Il. 1.142), 'godlike' (Il. 1.154), and 'lionhearted' (Il. 7.265).

${ }^{30}$ Hawhee (2002) 187. See also Finkelberg (1998) 24.

${ }^{31}$ Griffin (1980) 81-102.

32 Translation by Freese (2020).

${ }^{33}$ Ball (1995) 74. Adkins likewise believes 'virtue' to be a somewhat incorrect English translation of arete, see Adkins (1984) 32. Others have similarly commented on the difficulties in treating aretē, see Cherry (1988) 254; Grimaldi (1980) 194-5.
} 


\section{Ciceronian Ethos}

In the most rudimentary terms, because Aristotle is our best guide to Peripatetic rhetorical theory, and Cicero has demonstrated knowledge of the Peripatetic tradition, we are able to deploy Aristotle in order to illuminate Cicero's own theoretical background. As a result, the relationship between Aristotle's and Cicero's rhetorical theorising has received extensive analysis. ${ }^{34}$ While I do not propose that Cicero directly modelled his epistolary self-fashioning after Aristotelian ethos, a brief assessment of the extent to which he was familiar with, and influenced by Aristotle's Rhetoric will prove useful. That Cicero favoured the Peripatetic rhetorical tradition is certainly evident in his De Oratore, a dialogue for which he cites Aristotle as a source of inspiration (Fam. 1.9.23). ${ }^{35}$ The work signals a return to the Aristotelian pisteis as the foundation of oratorical composition by way of a series of structural and thematic parallels. ${ }^{36}$ In particular, Cicero very clearly revives Aristotle's tripartite system of proofs, stating

Thus, for purposes of persuasion the art of speaking relies wholly upon three things: the proof of our allegations, the winning of our hearers' favour, and the rousing of their feelings to whatever impulse our case may require (De or. 2.115-6). ${ }^{37}$

Here, Aristotelian ethos, pathos, and logos is remodelled as Ciceronian conciliare, movere, and probare. ${ }^{38}$ Much like ethos in the Rhetoric, conciliare, the winning of the hearers' favour, is highlighted in De Oratore as being the most crucial element of a persuasive speech (De or. 2.178).

\footnotetext{
${ }^{34}$ Wisse (1989) is fundamental, he traces the development of ethos and pathos from Aristotle to Cicero, drawing distinct structural and thematic parallels between Rhetoric and De Oratore; likewise, Solmsen (1941) 169-90 proposes that Cicero's De Oratore directly revived and renewed Aristotle's Rhetoric and his system of proofs; Fantham (1973) 262-275 discusses parallels in the rhetorical terminology employed by Aristotle and Cicero; Fortenbaugh (1992) 207-244 makes an argument against Cicero's direct knowledge of Aristotle, he contends that Cicero only possessed an indirect and approximate understanding of the Rhetoric; more generally, Barnes (1997) 1-69 traces the means by which Aristotle's texts reached Rome; see also Gill (1984); see also May (1988); Fortenbaugh \& Steinmetz eds. (1989); Kennedy (1972); Meyer (2000); Fantham (2004).

${ }^{35}$ Cicero professes his admiration for Aristotle on a number of occasions, see e.g. De or. 2.160 Acad. 4.18; Div. 1.53; Luc. 2.132; Tusc. 1.22. See Barnes (1997) p. 52.

${ }^{36}$ Samponaro (2007) 6-7; Barnes (1997) 46. In Cicero's earlier works (e.g. De Inventione) he favoured the Hellenistic rhetorical tradition. See Solmsen (1941) 178; May (1988) 3.

${ }^{37}$ Translation by Sutton \& Rackham (1942).

${ }^{38}$ Solmsen (1938), Fantham (1973), and Wisse (1989) all concur that these can be interpreted as parallel terms in the context of rhetorical theory. For conciliare/delectare, movere, and probare/docere as tasks that the orator must perform see also De ort. 2.128-9; 310; 3.104; Orat. 69; Brut. 185.
} 
Moreover, Cicero outlines the necessary characteristics an orator ought to demonstrate if he is to successfully earn this goodwill. "It is very helpful", he claims, "to display the tokens of goodnature, kindness, calmness, loyalty (...) and all the qualities belonging to men who are upright" (De or. 2.182). The ideal orator must establish, as part of his character, that he is virtuous, has achieved much, and has led a reputable life (De or. 2.182). By placing such an emphasis on merit and integrity, it is evident that conciliare, like ethos, is fundamentally concerned with the credibility of the speaker. ${ }^{39}$ In this, Cicero concurs with Aristotle. The more virtuous a man appears, the more likely he is to be trusted, therefore the greater his power of persuasion over the audience will be.

On the other hand, as Kennedy (1972), May (1988), and more recently Dugan (2005) have examined, Ciceronian ethos is necessarily broader than that of Aristotle for it is "influenced and conditioned by the idiosyncrasies of the socio-political environment of Republican Rome" ${ }^{40}$ Character, both personal and ancestral, was radically important in Roman society, particularly amongst the elite. ${ }^{41}$ As something "bestowed by nature", character did not evolve or develop. ${ }^{42}$ Rather, owing to an intrinsic veneration of the mos maiorem, character was perceived as hereditary; qualities of the parents spoke to that of their children. ${ }^{43}$ Cato the Elder attests to this generational constancy in his speech De Sumptu Suo. In it, he constructs his defence not simply on the basis of his own reputation, but that of his ancestors' (ORF 8.173). ${ }^{44}$ The implication here is that the charges against him are "inconsistent with the criterion of both his individual ethos and the collective character of his gens"; therefore, they must be false. ${ }^{45}$ The well-known Scipionic

\footnotetext{
${ }^{39}$ Cherry (1988) 256.

${ }^{40}$ May (1988) 6. May is essential for assessing ethos in Cicero's speeches. He examines orations from four different periods in Cicero's life to trace the changes in his own self-presentation and how he presents others. Any alteration to his persona, May shows, is to maximize the persuasive effect of the performance on the audience.

${ }^{41}$ This, of course, is a large topic. Gill (2006) is a good starting point for understanding Roman and Hellenistic conceptions of the 'self'.

${ }^{42}$ McClintock (1975) 39; May (1988) 6. See also Cic. Sull. 69, 79; Amic. 32.

${ }^{43}$ McClintock (1975) 39; Tatum (2015) 259. For more on mos maiorem, ancestral tradition, and the inheritance of character/virtue in Rome see e.g. Flower (1996); Treggiari (2003) pp. 139-64; Blom (2010) 12-17, 87-103, 316-17.

44 This reference is to Malcovati (1995). See Bibliography for full entry.

${ }^{45}$ May (1988) p. 6.
} 
Epitaphs similarly demonstrate this emphasis on inherited virtue. These inscriptions formulaically situate the deeds of the dead against those of their ancestors, praising them for upholding and surpassing their inherited virtus. The tomb of Gnaeus Cornelius Scipio Hispanus, for instance, records: "I upheld the praise of my ancestors, so that they are glad I was created in their line" (CIL 6.1293). ${ }^{46}$ To be "a good man born of good parents" was in essence the highest praise a Roman could bestow. ${ }^{47}$ Ancestry, then, becomes an inherent aspect of one's social authority and plays a central role in the determination of character in the Roman context.

Just as it was understood to be generationally constant, so too was character believed to be constant within the individual. One's nature, so Cicero claims, cannot be altered at will or in any permanent sense, nor can any good come from an attempt to do so (Off. 1.107-110). Rather, he continues, the very best men are those who maintain uniform self-consistency throughout the entire course of their lives (Off. 1.111-114). Such preservation of character can only be achieved, however, if one plays a role appropriate for, and in accordance with, their intrinsic nature. ${ }^{48} \mathrm{After}$ all, actors, "select not the best plays, but the ones best suited to their talents" (Off. 1.114) ${ }^{49}$ For an elite Roman, the role most appropriate to his nature was one in which he demonstrated possession of dignitas, gratia, gloria, and auctoritas. ${ }^{50}$ In essence, each of these aristocratic virtues worked to communicate one's elite persona, signalling to his community that his character was deserving of respect and deference. There was an expectation in Rome to accept the judgement of those whose character was perceived as superior. ${ }^{51}$ However, to construct this

\footnotetext{
${ }^{46}$ Translated by Warmington (1940).

${ }^{47}$ McClintock (1975) 39.

${ }^{48}$ Miles (1996) 19, 30-33.

${ }^{49}$ Translation by Miller (1913).

${ }^{50}$ May (1988) 6-7. For these aristocratic virtues see Cic. De Inv. 2.34, 166; Off. 2.31-51; De or. 2.334. On dignitas see also Syme (1939) 11; Earl (1967) 11. On gloria see also Earl (1967) 30; Tatum (2015) 37. On auctoritas see also Syme (1939) 153; Earl (1967) 33; Heinze (1925) 348-346.

${ }^{51}$ See e.g., Vergil's simile in Aeneid 1.167-84 for an expression of the power of auctoritas over a rioting crowd. It was through various performative institutions that Roman citizens were systematically conditioned to respect the authority of the elite. Triumphs, funeral processions, ceremonial public speeches and eulogies, games sponsored by wealthy benefactors, religious rites performed by elite priests, and even public architecture all fostered aristocratic prestige. The result is a deeply rooted impulse to defer to the judgement of the elite, to revere the mos maiorem, and to trust that Rome was best left in the hands of those who were superior by virtue of their ancestry. For more on elite superiority in Rome see Hölkeskamp (2004); Morstein-Marx (2004); Sumi (2005) pp. 1-46.
} 
superior character, one first had to demonstrate practical experience, expert knowledge, and "a sense of responsibility in both private and public life". ${ }^{52}$ Such competence was the result of dedication and maturity; it demanded a life-long commitment to the aristocratic performance. Be it a public speech, the writing of a letter, or simply a walk around the Forum, every act had to conform to social expectations and ultimately contribute, in some capacity, to his reputation (Cic. Off. 1.107-14). ${ }^{53}$ Here, because character was a seen as "diachronic development of one's dignitas, auctoritas, and future gloria", the Roman self was ultimately "a continual work in progress". ${ }^{54}$ Ciceronian ethos, then, is "long-range". ${ }^{55}$ That is, where Aristotle's ideal rhetorician should not reach beyond the parameters of the speech in order to construct his persona (Arist. $R h$. 1.1356a4), Ciceronian ethos was intended to be fashioned from a wealth of external sources. ${ }^{56}$ In any case, be it Ciceronian or Aristotelian, ethos is fundamentally concerned with the phenomenon of self-representation and audience manipulation $(R h .1 .1266 \mathrm{a} 8-16$; De or. 2.178). It is for this reason that this thesis draws on both. While I take Aristotle's categorisation of ethos into phronesis, eunoia, and aretē as a framework, it is Cicero's "more dynamic conception of ethos" which informs my analysis of his epistolary self-fashioning. ${ }^{57}$

\section{Epistolary Ethos}

While correspondence is clearly distinct from that of oratory, a rhetorical treatment of the letters is possible because they too constitute rhetorical occasions ${ }^{58}$ Aristotle determines that every piece of persuasive discourse consists of three parts: the speaker, the subject he is treating, and the audience to whom it is addressed (Arist. $R h$. 1358a22). This tripartite classification of rhetorical discourse is easily reflected in the exchange of correspondence; the orator of Aristotle's model becomes the letter-writer, the speech's subject is contained within the letter, and the orator's

\footnotetext{
${ }^{52}$ May (1988) p. 6; Heinze (1925) pp. 363-366.

${ }^{53}$ See e.g., the Commentariolum Petitionis for aristocratic pageantry while canvassing. Fundamental on the collective identity and performative character of the Roman aristocracy is Hölkeskamp (2011); see also Earl (1967); Tatum (2015).

${ }^{54}$ Samponaro (2007) 14-21. See also May (1988) 9.

${ }^{55}$ Enos and McClaran (1978) 102.

${ }^{56}$ Meyer (2000) 8; Wisse (1989) 245-8; May (1988) 9; McClintock (1975) 39.

${ }^{57}$ Meyer (2000) 8.

${ }^{58}$ Meyer (2000) 3.
} 
audience becomes the letter's addressee. ${ }^{59}$ Furthermore, the notion of the rhetorical letter, though not extensively treated until the publication of De Elocutione sometime in the first century AD, is one which is reflected by a number of ancient rhetoricians. ${ }^{60}$ Indeed, ancient epistolary theory in general "belonged to the domain of the rhetoricians"; most Roman letter writers were orators and, as such, their conception of the epistolary system was intrinsically coloured by their rhetorical training. ${ }^{61}$ Cicero himself was most likely familiar with handbooks on letter writing. In his well-known letter to Curio, he acknowledges that the "tone" of a letter is determined by its subject matter, and it is on the basis of this tone that correspondence can be classified into various genres (Fam. 2.4.1). ${ }^{62}$ The two genera he enjoys most are the "familiar and jocular" kind, and the "serious and grave" kind (Fam. 2.4.1). Though his comments do not point to any kind of epistolographic system, they nonetheless show "authorial brooding" and "self-conscious artistry", reflecting a Roman awareness of epistolary theory and rhetoric. ${ }^{63}$ Later, both Seneca the Younger and Quintilian make similar remarks, observing that only certain styles were appropriate to a letter (Sen. Ep. 40.1, 62.7, 75.1; Quint. Inst. 9.4.19). What is more, Aelius Theon, in his progymnasmata, goes so far as to suggest that letter writing works well as an "exercise in characterisation" ( $R G$. 2.115.22) ${ }^{64}$ While no explicit rhetorical system existed in the realm of early epistolography, each of these instances, at the very least, suggest that correspondence was certainly of interest to rhetoricians.

Regarding ethos, that the letter is able to reflect the character of its writer is undoubtedly one of the oldest recognized features of the ancient epistolary tradition. Demetrius, in his $D e$ Elocutione, establishes that

\footnotetext{
${ }^{59}$ Bernard (2013) 175; Meyer (2000) 74.

${ }^{60}$ Malherbe (1988) 2.

${ }^{61}$ Malherbe (1988) 2.

${ }^{62}$ Sogno (2014) 203.

${ }^{63}$ Hutchinson (1998) 8. See also Malherbe (1988) 3; Wilcox (2012) 18-20. Cicero also speaks of choosing a suitable type of letter for the situation in Fam. 4.13 and 6.10b. On Cicero as an important authority for epistolary theory see Poster (2007b) 39.

${ }^{64}$ This is a reference to Leonhard von Spengel (ed.) Rhetores Graeci vol. 2 (Stuttgart: B.G. Teubner) 1854. See also Malherbe (1988) 3; Kennedy (1972) 615-6.
} 
Like the dialogue, the letter should be strong in characterisation. Everyone writes a letter in the virtual image of his own soul. In every other form of speech, it is possible to see the writer's character, but in none so clearly as in the letter (Demetr. Eloc. 227) ${ }^{65}$

Quintus Cicero likewise reflects on this phenomenon, claiming his brother's very essence was revealed to him in a piece of correspondence (Fam. 16.16.2). This notion that a letter provided some window into the soul of its writer is indeed a traditional one. Petrarch famously criticised the perceived transparency of Cicero's correspondence. He believed that the medium facilitated inappropriate candour which, in Cicero's case, broke the illusion of him as a powerful statesman (Petrarch, Epistolae Familiares, 24.3). By contrast, Montaigne later rejoiced in the letter's capacity for such genuine character portrayal; the opportunity to "pry into the souls and the natural and true opinions of the authors" was invaluable to the French author. ${ }^{66}$ Though compelling, it was observations such as these which ultimately contributed to the myth of epistolary sincerity so rife in earlier scholarship. The tendency in the $19^{\text {th }}$ and $20^{\text {th }}$ centuries was to treat Cicero's correspondence, as a "sincere outpouring" which offered personal perspective and revealed the writer's truest self. ${ }^{67}$ Indeed, often employing simple conversational language and familiar, personal themes, the correspondence, as Peter White notes, very much lent itself to a candid interpretation. ${ }^{68}$

Modern scholarship, however, favours a more literary treatment of Cicero's letters, the result of which has been a rejection of epistolary veracity. By approaching ancient correspondence as a self-conscious literary artefact, scholars have come to understand that the essence of sincerity which exists within many letters is there only because the writer, through his strategy of selfpresentation, has made it so. ${ }^{69}$ That is, though "built out of realities", epistolary personae are

\footnotetext{
${ }^{65}$ Translation by Roberts (1995).

${ }^{66}$ Michel de Montaigne, Essais, volume 1, chapter 39. Translation by Cotton (1887).

${ }^{67}$ Fulkerson (2013) 246. See also Bernard (2013) 172.

${ }^{68}$ White (2010) 5.

${ }^{69}$ White (2010) 5. This is not to say letters are entirely void of sincerity. Cicero's exilic correspondence is generally accepted to be more candid than the other letters in his oeuvre. Likewise, his letters to Atticus tend to be interpreted as more sincere than others. See Bernard (2013) 169-70.
} 
highly affected. ${ }^{70}$ Like the orator, the addresser has a rhetorical objective and he uses ethos to achieve it. Employing various literary techniques, rhetorical devices, and epistolary conventions, he constructs a persona that renders him credible and persuasive. Demetrius, then, was not wrong in his assessment. A letter certainly does reflect the character of its writer, only, it is one which has been carefully manufactured.

Here, the study of epistolary persuasion among the Roman aristocracy is a comparatively new field in classical studies. Hutchinson (1998) marked a turning point by vigorously countering (what he perceived to be) the widely held view that Cicero's correspondence was of little literary value. ${ }^{71}$ Through close, formal analysis, he assesses differences in Cicero's style between, for example, his exilic correspondence and consolation letters. ${ }^{72}$ The result reveals a high level of authorial intent and calculated strategies of persuasion throughout the epistles. Hutchinson likewise highlights parallels between the statesman's letters and his speeches, concluding that they find commonality as discourse directed at, and designed to influence, a specific identifiable audience. $^{73}$

More recently, Meyer's (2000) dissertation offered a fundamental treatment of Cicero's correspondence as a set of rhetorical documents. She uses rhetorical theory to assess Cicero's 'ethopoetic' use of amicitia in his letters between 63 and 55 BC. Focussing especially on his correspondence with Celer, Pompey, Atticus, and Lucceius, Meyer argues that amicitia played an essential role in Cicero's epistolary self-fashioning. That is, the persuasive objective of each letter relied on "the convincing portrayal of author and addressee as amici". ${ }^{44}$ What is more, she employs May (1988) as a methodological model. ${ }^{75}$ Though his work, as mentioned above, examined a different genre, May's close analysis of Cicero's oratorical self-fashioning at different career stages revealed that ethos was perhaps his most important source for persuasion. As the

\footnotetext{
${ }^{70}$ Hutchinson (1998) 138. Other important literary readings of Cicero's letters include Bernard (2013); Morello \& Morrison (2007); Wilcox (2012);

${ }^{71}$ Hutchinson (1998) 2-8.

${ }^{72}$ E.g., Hutchinson (1998) 28-33.

${ }^{73}$ E.g., Hutchinson (1998) 30, 64, 101.

${ }^{74}$ Meyer (2000) 161.

${ }^{75}$ Meyer (2000) 12.
} 
statesman dealt with changing circumstances and challenges, he expertly curated different personae within his speeches to achieve different rhetorical goals.

Next, Hall (2009) identified Cicero's letters - rather than his orations or technical writings - as a source for the examination of his social, political, and literary ambitions. ${ }^{76}$ Informed by sociolinguistic theories of politeness, the author closely examines how Cicero and his various correspondents employed rhetorical strategies, goodwill and affection within the letters to fulfil aristocratic obligations of etiquette. ${ }^{77}$ These incredibly deliberate strategies of politeness, he reveals, were essential to the success of elite negotiations-particularly, as we will see, in times of political crisis such as the aftermath of the Ides of March. ${ }^{78}$

Finally, White (2010) took a more philological approach to the corpus. He usefully unpacks the various conventions of ancient letter-writing and considers what differentiates 'literary' letters from 'non-literary letters' ${ }^{79}$ Importantly, in his final chapter, White closely analyses select letters written between 44 and $43 \mathrm{BC}$, examining how Cicero manipulates language, conventional formulae, and advice-giving techniques to manoeuvre his addressees. ${ }^{80}$ Indeed, it is an observation he made about the post-Ides corpus which prompted my own interest in this correspondence. White explains that the letters between 44 and $43 \mathrm{BC}$ are often regarded by historians as having "limited value" because a) parallel sources more thoroughly establish the narrative of the time b) the letters are "spare on facts" and often contribute only "sidelights", and c) "the perspective they illuminate is that of history's losers rather than of the winners, in whom we are always more interested" ${ }^{81}$ In opposition to these views, he instead asserts that Cicero's post-Ides correspondence is a crucial source for analysing "elite motivation in a crisis that put values to the test" ${ }^{82}$ The highly rhetorical nature of the letters allows us to examine how Rome's

\footnotetext{
${ }^{76}$ See Sarah Stroup's review of Jon Hall (2009) in The Classical World (Vol. 104. No. 2) 2011 245-255.

${ }^{77}$ Hall (2009) 5-27.

${ }^{78}$ Hall (2009) chapter 5 is entirely devoted to the tense post-Ides period and the role that polite epistolary language played in political negotiations. He specifically looks at the relationship between Brutus, Cassius, and Mark Antony on the one hand, and that of Cicero and Plancus on the other,

${ }^{79}$ White (2010) chapter 4.

${ }^{80}$ White (2010) chapter 6.

${ }^{81}$ White (2010) 164.

${ }^{82}$ White (2010) 164.
} 
leading men construct and maintain both their personal images and their personal networks in the wake of Caesar's death. In this thesis I elaborate on these ideas by assessing Cicero's correspondence through the lens of ethos to reveal three distinct instances of persona creation. The result is to demonstrate the invaluable role that his post-Ides correspondence played in his self-fashioning of fresh authority between 44 and $43 \mathrm{BC}$.

\section{The Aftermath of the Ides of March}

Cicero's epistolary construction of self after the Ides of March is undoubtedly "one of the greatest sustained performances of his career" ${ }^{83}$ In order to fully appreciate just why this is so, it is necessary to contextualize the letters with a brief summary of events. The central figures in the conspiracy were of course Brutus, Cassius, and Decimus; each of whom was united by their animosity towards Caesar's increasingly tyrannical behaviour (Nic. Dam. F130, 19.59; App. B Civ. 2.464; Cass. Dio. 44.14.3-4; Suet. Iul. 80.3-4; Plut. Vit. Caes. 66). ${ }^{84}$ After the group had murdered the dictator on March 1544 BC, according to Antony, it was Brutus who "raised his bloodstained dagger high, called on Cicero by name, and congratulated him on the recovery of freedom" (Cic. Phil. 2.12). Though he had consistently maintained his innocence, Cicero "never denied the historicity of the episode" ${ }^{85}$ He claimed that the Liberator had called out his name merely to illuminate the parallels between this achievement and his own execution of the Catilinarian conspirators twenty years prior (Cic. Phil. 2.12). Nevertheless, when Brutus let out his cry, Cicero became deeply embroiled in the conspiracy. To be sure, the elderly statesman did later lament his lack of involvement, and it is no secret that he harboured anti-Caesarian sentiments (Fam. 10.28.1). Some two years earlier, when Caesar had well and truly imposed his will over Italy, Cicero left a decidedly charged message for Brutus in his dialogue of the same

\footnotetext{
${ }^{83}$ White (2010) 138.

${ }^{84}$ For modern accounts of Caesar's assassination see e.g. Tatum (2008) 145-166; Rawson (1994) 464-73; Syme (1939) 95-104. It also bears noting that the language used to describe the conspirators is polarising. On one hand, they are classed as assassins and murderers with invective terms such as sicarii, parricidae, and interfectores, see e.g. Fam. 12.3.1; Cic. Phil. 2.13.31; Nep. Att.8.3. On the other hand, the conspirators are regarded more favourably with terms such as liberatores, heroes, and tyrannoctoni, see e.g. Cic. Phil. 1.2.6; Att. 14.12.2; Att. 14.6.1; Att. 14.15.2. I employ all terms interchangeably in this thesis.

${ }^{85}$ Leber (2015) 31-2; Lintott (2008) 339.
} 
name, urging him to emulate his illustrious ancestors - those who had deposed kings and assassinated suspected tyrants (Cic. Brut. 331). It was a conspicuous display of Cicero's burgeoning distaste for the dictator's regime and he had conveyed similar sentiments in a letter to Atticus (Att. 12.45.2) ${ }^{86}$ The statesman, then, was certainly sympathetic to the Liberators cause. $^{87}$

However, somewhat naïvely—so Cicero thought—-the conspirators had believed they would be universally celebrated as tyrannicides upon completing their deed (Att. 14.21.3). They had hoped Caesar's partisans would recognize the assassination for what it was, an act of liberation, and immediately cooperate to restore the res publica. While the Liberators awaited public recognition as saviours of Rome, Antony, the sole-remaining consul and now effectively Caesar's successor, sought the allegiance of other loyal Caesarians. He understood that genuine power rested in the military. Thus, Antony secured as an ally Lepidus, Caesar's magister equitum, who in turn moved troops into the Campus Martius for use at the consul's behest. ${ }^{88}$ The plebs, whose cause the dictator had championed, likewise reacted with hostility. With the illusion of heroism shattered, the Liberators took themselves to the Capitol for safety where they were subsequently besieged (Cass. Dio. 44.21-22; Plut. Vit. Caes. 67; Suet. Iul. 82; Fam. 11.1). ${ }^{89}$ Despite this conflict, in a demonstration of political acumen, Antony called for a meeting of the Senate in the Temple of Tellus on March 17 (Phil. 1.1, 31, 2.89; Att. 16.14.1; App. B Civ. 2.525526; Cass. Dio. 44.22.3, 46.28.3). Both he and Cicero were active throughout the assembly. Antony praised Caesar's commitment to concord and, when others demanded that the dictator be ruled a tyrant and his acta invalidated, he reminded the senators present that it was precisely these acts which had guaranteed a number of them the prestige of a state office (Plut. Vit. Cic. 42.2-3; App. BCiv. 2.128). Unwilling to risk their offices, the senators hesitated. Cicero himself, evoking Athenian precedent, proposed amnesty. Ultimately, it was agreed that peace would be reached

\footnotetext{
${ }^{86}$ Lintott (2008) 339; Lintott (2009) 75.

${ }^{87}$ Huzar (1978) 81.

${ }^{88}$ Huzar (1978) 82.

${ }^{89}$ See also Lintott (2009) 79-80 for the events in the days following Caesar's assassination.
} 
through compromise; in return for the Liberators' pardon, Caesar would not be declared a tyrant and his acta would remain intact (App. BCiv. 2.126-29; Plut. Vit. Cic. 42.3; Vit. Caes. 67.9; Vit. Brut. 19.1; Vit. Ant. 14.2; Cass. Dio 44.22-34; Cic. Att. 14.6.2; 14.9.2; Fam. 12.1.2).$^{90}$ This meant that the assassins Decimus, Trebonius, and Cimber retained the provinces assigned to them by Caesar; most importantly, Decimus would possess valuable proconsular imperium and an army of two legions. ${ }^{91}$ Dolabella inherited the dictator's consulship for the remainder of the year but his consular colleague Antony, now in control of Caesar' acta, was truly the dominant force in Rome. ${ }^{92}$ In any case, having received as hostages the sons of both Antony and Lepidus, the Liberators felt it safe enough to leave their position on the Capitol. At the crowd's insistence, Caesarians and Liberators shook hands and dined together (Cass. Dio. 44.34.6-7; Plut. Vit. Ant. 14.1-2). Thus, on March 17 each faction had committed itself to some form of cooperation, however fraught or fractious.

Unfortunately, it was not long before Cicero's greatest fear became a reality and Antony started to engage in conduct that resembled a campaign for sole-rule. Already his display of political acumen in orchestrating the amnesty had identified him as an illustrious figure in Rome: people hailed him as the consul who had brought an end to civil war (Plut. Vit. Ant. 14.2). It was Antony's performance at Caesar's funeral only several days after the amnesty, however, which was especially worrying (Plut. Vit. Cic. 43.1-2). He had been selected-as co-consul, relative, and friend of Caesar - to deliver the customary eulogy over the dictator's body in the Forum (App. BCiv. 2.143). Antony carefully curated the display in order to "win the emotional allegiance of the people without alienating the republican senators" ${ }^{93}$ He highlighted the "religious culpability" of the conspirators by emphasising the various senatorial oaths designed to protect Caesar, emphasising phrases such as "sacrosanct and inviolable", "father of his country", "benefactor",

\footnotetext{
${ }^{90}$ Butler (2002) 104; Lintott (2009) 80; Syme (1939) 139; Knight (1968) 157; Huzar (1978) 82-3.

${ }^{91}$ Decimus was assigned Cisalpine Gaul, Trebonius had Asia, and Cimber had Bithynia. See Huzar (1978) 83.

${ }^{92}$ Huzar (1978) 84.

${ }^{93}$ Huzar (1978) 85.
} 
and "protector without equal" (App. BCiv. 2.144) ${ }^{94}$ Swept up in emotion, the consul uncovered Caesar's body and paraded his bloodied toga before the masses (App. BCiv. 2.146; Plut. Vit. Ant. 14). At this the crowd became overwhelmed by grief and spontaneously cremated Caesar in the Forum itself; so too did they destroy the Curia, kill the tribune Cinna, and plan to set fire to the houses of the conspirators (App. BCiv. 2.147; Plut. Vit. Ant. 14.4; Vit. Cic. 42.2ff; Vit. Brut. 20.3; Cic. Att. 14.10.1). The conspirators and many of their sympathisers - including Cicero-fled the city in fear. Antony, then, had skilfully manipulated Caesar's funeral to increase his dominance in Rome. ${ }^{95}$

Though the amnesty held, his conduct continued to worsen. As noted, Antony's strongest source of authority was in the army. By late April $44 \mathrm{BC}$ he had convinced the Senate to grant him a private bodyguard and had called upon 6,000 Campanian veterans (Cic. Fam. 10.30.1; Att. 16.8.2; Phil. 1.27; 2.100; App. BCiv. 3.4-5). ${ }^{96}$ What is more, though he had been assigned to govern Macedonia and its four legions after his consulship, Antony objected to the allotment for he wanted to be closer to the power in Rome. ${ }^{97}$ Thus, he summoned a meeting of the Senate on June 1 , one which republican senators did not attend for the assembly was surrounded by the consul's guard. There he "pushed a tribunician law through the Comitia Tributa" and took for himself Decimus' province of Gallia Cisalpina while also retaining possession of his Macedonian legions (Cic. Phil. 1.6; 5.7; Att. 14.14.4; 15.4.1). ${ }^{98}$ Decimus was demoted to an assignment in Macedonia without an army, a massive blow to the republicans and one they later would not accept. Not long after, Brutus and Cassius were assigned a grain commission in Crete and Cyrene respectively. Though well below their rank, it was agreed in a group meeting at Antium that to accept the commission was the best (if not only) option for at the very least it gave them a sound reason to leave Italy (Cic. Att. 15.9-12; 15.17; 16.4; ad Brut. 1.15.4-6). ${ }^{99}$ They set off east

\footnotetext{
${ }^{94}$ Tatum (2020) 196. On Antony's speech at Caesar's funeral see also Kennedy (1968).

95 Huzar (1978) 85.

96 Huzar (1978) 86.

97 Habicht (1990) 78; Huzar (1978) 86; Syme (1939) 110.

${ }^{98}$ Gallia Cisalpina was considered foundational to the military control of Italy. See Huzar (1978) 91; Habicht (1978) 78; Syme (1939) 110.

${ }^{99}$ Leber (2015) 186; Huzar (1978) 91-2.
} 
seemingly to undertake their official assignments, but in reality, the Liberators were resolved to raise funds and appropriate Macedonia and Syria as military bases from which to plan their next moves. ${ }^{100}$ Meanwhile, Cicero had decided to go to Greece until the new consuls Hirtius and Pansa would replace Antony in 43 BC. While he had initially praised Antony for his good statesmanship (Cic. Phil. 1.2-4) and expressed an eagerness to keep their friendship intact (Fam. 16.23.2; Att. 14.13b), Cicero's private correspondence reveals increasing anxiety over the danger that the consul posed to Rome. Furthermore, it was becoming clear to him that the conspirators had lost their vigour; rather than leading the res publica, they were in "disordered retreat". ${ }^{101}$ It was up to Cicero, then, to direct affairs and unite the fractious Senate against its most formidable threatAntony.

${ }^{100}$ Huzar (1978) 92.

${ }^{101}$ Huzar (1978) 92. 


\section{Chapter One \\ Phronesis: Cicero as Nestor}

$\ldots$ and yet the illustrious Grecian chief never prays for ten men like Ajax, but for ten

like Nestor, and he doubts not that, if he had them, Troy would be speedily destroyed

(Cic. Sen. 31). ${ }^{102}$

The superiority of the wise elder over that of the young warrior is a theme which considerably informs Cicero's post-Ides construction of ethos. Too old for active involvement and lacking the senate as his "right hand", Cicero's only chance at steering the res publica after Caesar's death rested almost solely on his ability to stand as a sagacious and exemplary advisor to the younger generals of the state (Fam. 11.14.1) ${ }^{103}$ Rather than base his authority on political or martial prestige, it was upon his wisdom, intellect, and practical experience that the statesman had to rely. ${ }^{104}$ This chapter examines how Cicero, taking Nestor as his model, demonstrates phronesis to render his younger correspondents more receptive to counsel. As we have seen, phronesispractical wisdom, good sense, prudence- is an intellectual virtue which allows the rhetorician to establish credibility on the basis that he is experienced, well-reasoned, and an excellent decisionmaker. Possession of such wisdom is a privilege awarded to men of old age who are among the senatorial rank for their life-experience is inherently greater. ${ }^{105}$ Ultimately, it signals one's capacity to, in a given situation, arrive at a reasonable decision and provide effective advice. Such is the post-Ides image that Cicero needed to establish. Within the letters he, like Nestor, draws heavily on his status as a senex to emphasise his own authority in the present. By recalling instances of past greatness, his consulship included, Cicero demonstrates unprecedented experience in the defence of libertas and the res publica. This is a display of phronesis which works to position the statesman as both a credible counsellor and an exemplum to his younger correspondents. What is more, he employs this superior insight to fashion himself as a prophet-

\footnotetext{
102 Translation by Falconer (1923).

103 Blom (2010) 135. See also White (2010) 141; Dugan (2005) 20.

104 Dugan (2005) 20.

${ }^{105}$ Hellegouarc'h (1963) 258. Hellegouarc'h here is describing prudentia, a Latin equivalent of phronesis.
} 
like figure. The product of "broad learning" and decades of political involvement, foresightedness is a vital component of phronesis for it permits an individual to advise in accordance with future outcomes. ${ }^{106}$ In criticizing those who had previously failed to heed his accurate advice, Cicero highlights his own ability to accurately predict future events before they occur. Such an oracular talent thus renders his counsel worthy of consideration.

At the same time, these elements of phronesis which Cicero employs to position himself as a sage advisor are used to fashion an ethos of withdrawal. Already in April $44 \mathrm{BC}$ he had become disillusioned by the Ides of March and sought to take on a more passive role in the running of the state. To save face during this departure, Cicero presented himself as a senex simply too old to fight. Having already served the Republic to his fullest extent, the senior statesman demonstrates that he is justified in shifting the responsibility of leadership onto the likes of Brutus and his Liberators. This, however, does not signify his intent to become a passive observer. Rather, Cicero will exchange politics for philosophy. Wisdom and intellectual inquiry have armed the statesman against the "assaults of Fortune" and are his new weapons of choice in the fight against Antony (Fam. 12.23.4). Ultimately, then, this chapter considers how Cicero employs elements of phronesis within his correspondence to project a passive, yet authoritative post-Ides ethos. Old age, past experience, and foresight render Cicero a voice of reason whose guidance implicitly warrants the approval of his younger addressees. At the same time, as a Nestor-like figure, the statesman has already discharged his duties to the Republic and is better placed to serve Rome in his capacity as a philosopher.

${ }^{106}$ Mitchell (1991) 19; Aubert-Baillot (2015) 69. 


\section{The Nestor Exemplum}

That Cicero sought to model his post-Ides ethos on Nestor is nowhere more conspicuous than in his letter to Dolabella on May 344 BC. Having praised his now ex-son-in-law for exercising sound judgement, the statesman markedly adds

And yet it detracts nothing from your prestige to have a Nestor to consult, as did the King of Kings, Agamemnon himself, without any loss of dignity (Fam. 9.14.2).

Such deliberate self-fashioning first and foremost raises the question, why Nestor? This is certainly not the first time Cicero has employed historical exempla to cast himself in the role of advice-giver to the powerful. ${ }^{107}$ Still experiencing the elating afterglow of his consulship in 63 $\mathrm{BC}$, he had tried in a letter to position himself as "a Laelius to Pompey's Scipio", unfortunately to no avail (Fam . 5.7.3). ${ }^{108}$ Years later, Cicero again entertained the idea of embodying the sagacious counsellor. This time, he would be "an Aristotle to Caesar's Alexander". ${ }^{109}$ In May 45 BC he wrote to Atticus and complained that he was in something of a predicament; despite repeated attempts, Cicero could not decide on how best to compose a letter of advice to Caesar (Att. 12.40.2, 13.26.2, 13.28.2-3). Though he had as exempla the advisory letters from Aristotle and Theopompus to Alexander the Great, they seemingly offered little inspiration for his own piece of correspondence (Att. 12.20.2). Certainly, the letter of advice was a genre with a long-standing history. Particularly common in the Hellenistic period, as Sean McConnell notes, such correspondence helped to facilitate frank dialogue between a philosopher and his sovereign. ${ }^{110}$ Aristotle's letters to his pupil Alexander, which now served as Cicero's paradigm, were indeed well-known examples of the convention. Few references to the contents of these epistles survive, but we know that Cicero himself admired the correspondence simply because it set out to exhort Alexander to "honourable distinction" (Att. 13.28.2). ${ }^{111}$

\footnotetext{
${ }^{107}$ An excellent source on Cicero's use of personal exempla is Blom (2010) esp. 175-289.

108 Blom (2010) 291. See also Stockton (1971) 144-5; Habicht (1990) 40.

${ }^{109}$ Blom (2010) 291. See also Stockton (1971) 144.

${ }^{110}$ McConnell (2014) 198. See also Murray (1965) 179.

${ }^{111}$ Plut. Mor De Alex. fort. 329b and Ael. VH. 12.54 discuss the contents of the letters.
} 
In any case, it was this tradition of giving epistolary advice that the statesman sought to emulate. By doing so he hoped to "influence and relate to Caesar", a man who had recently been appointed dictator for the next ten years. ${ }^{112}$ While their personal relationship was one of careful respect, Cicero was wary of positioning himself as the dictator's mentor lest he cause offence (Att. 13.27.1). ${ }^{113}$ At the same time, however, he wanted to assert himself as a figure of sage authority and earn glory as a result. His solution was to send a draft of the letter of advice to Caesar's partisans Oppius and Balbus for evaluation (Att. 12.51.2, 12.52.2, 13.1.3). The outcome was, once again, less than desirable. Both Caesarians demanded revisions which, in Cicero's opinion, would undermine the entire objective of his letter and he ultimately decided not to send it to the dictator (Att. 13.27.1, 13.28.2). ${ }^{114}$ Had he sent the letter, Cicero would have succeeded only in "underscoring his position as a politician under the control of a dictator". ${ }^{115}$ Where Aristotle had succeeded in both pleasing Alexander and advancing his own reputation, Cicero was unable to strike this balance with Caesar.

If both Laelius and Aristotle had failed as exempla on which to model his ethos, why then did Cicero believe he would have success with Nestor as his post-Ides paradigm? An answer can be found in book one of the Iliad when Nestor is first introduced. He enters as the dialogue between Achilles and Agamemnon has all but deteriorated and immediately steps into the role of sage advice-giver:

Nestor rose between them, the man of winning words, the clear speaker of Pylos. Sweeter than honey from his tongue the voice flowed on and on. Two generations of mortal men he had seen go down by now, those who were born and bred with him in the old days in Pylos' holy realm, and now he ruled the third. He pleaded with both kings (...) 'Stop. Please. Listen to Nestor. You are both younger than I, and in my time I struck up with

\footnotetext{
112 McConnell (2014) 198.

${ }^{113}$ McConnell (2014) 197. See also Fam. 6.10a.2; Att. 14.17.6.

114 Blom (2010) 258-9; McConnell (2014) 197-8; Shackleton Bailey (1971) 219-20.

115 Blom (2010) 259.
} 
better men than you, even you, but never once did they make light of me (...) they took to heart my counsels, marked my words. So now you listen too' (Hom. Il. 1.290-320). ${ }^{116}$

Fundamentally, this exchange is a perfect exercise in the demonstration of phronesis to establish an authoritative ethos. As we have seen, one of vital components of phronesis is old age (Arist. Eth. Nic. 6.1142a10-15). This is because, as Plutarch later relates, elders possess a kind of caution and prudence that those who are young do not (Plut. Mor. An seni. 788c). In their old age they have experienced many successes and failures, all of which contribute to the cultivation of good sense and an understanding that crises are best managed moderately and gently (Plut. Mor. An seni. $788 \mathrm{~b}-\mathrm{d})$. In turn, it is this practical wisdom which marks elders as trustworthy figures whose advice therefore implicitly warrants approval. ${ }^{117}$

Nestor's dialogue above very clearly parallels these themes. He begins his appeal by emphasising his own "faintly preternatural" seniority. ${ }^{118}$ Reminiscing about his youth and the heroes with whom he adventured, he asserts that these warriors, having once triumphed over the Centaurs, were inimitable and far superior to the men of the present (Hom. Il. 1.307-13). Here, Nestor recalls "a past of which he is the sole representative" to illustrate that he is extremely wellversed in history's ebb and tide. ${ }^{119}$ His longevity has granted him unprecedented practical experience and the opportunity to cultivate wisdom superior to that of his younger more inexperienced peers. ${ }^{120}$ Thus, when he offers advice, those around him are inclined to listen. Even Achilles and Agamemnon, two men poised to duel, demonstrated obedience and came to an (albeit dysfunctional) agreement at Nestor's warning (Hom. Il. 1.334-364). ${ }^{121}$ Indeed, such a figure of guidance is Nestor that the false dream, sent by Zeus to fool Agamemnon, adopted his

\footnotetext{
116 Translation by Fagles (1998).

117 Dickson (1995) 105.

118 Martin (1989) 101.

119 Falkner (1989) p. 31. On Nestor's use of language, poetic recall, and memory in Homer see Martin (1989) 23-5, 52, 54, 59-61, 106-9; Dickson (1995).

${ }^{120}$ Fortenbaugh (1992) 212.

121 Of course, Athena also had a hand in checking Achilles' rage (Hom. Il. 1.227-61). On Nestor's intervention in book one of the Iliad see also Martin (1989) 101; Fortenbaugh (1992) 211-12. For other instances where Nestor has accrued respect on account of his old age see e.g. Hom. Il. 2.90-99, 7.371-396, 9.108-136; Od. 24.51-55. See Dickson (1995) 105.
} 
likeness (Hom. Il. 2.17-23). Agamemnon readily accepted this imposter's counsel because it was delivered in a "most honoured" voice of intelligence and prudence (Hom. Il. 2. 23). ${ }^{122}$ Nestor, then, is the ultimate "prototype of wisdom anchored in old age and experience". ${ }^{123}$ In him we find proof that, though old age may weaken physical strength, it enhances the mind's potential. ${ }^{124}$ What is more, Nestor uses this phronesis to fashion for himself an ethos which is credible and authoritative; any advice he gives therefore inherently deserves his audience's attention and support. ${ }^{125}$

Because he embodies the ideal sagacious elder, Nestor is employed as an exemplum in a number of philosophical works on the topic of old age. In his Moralia, for instance, Plutarch directly links Nestor to phronesis. He explains that an old man should use his wisdom to "act as a kind of umpire at the contest of political ambition" between younger men; if their debate should become unrestrained, he is to intervene with a mild rebuke and correct the behaviour without being too critical (Plut. Mor. An seni 795a-b). ${ }^{126}$ To illustrate his point, Plutarch recalls Nestor's speech in book nine of the Iliad (Plut. Mor. An seni 795b-c). After Diomedes had passionately criticised Agamemnon's order to sail home, the elder intervened with a more moderate call to arms; because of his old age, he claimed, not even the son of Atreus would react to his words with contempt, thus, and the men followed his lead (Hom. Il. 9.55-89). Just as in book one, Nestor's authority to direct the affairs of those younger than him stems not from his immediate martial prowess, but from his demonstrable wisdom and practical experience. Cicero's own important philosophical work on the subject of aging, De Senectute, parallels Plutarch's later Moralia and uses Nestor as a model for Cato the Elder. ${ }^{127}$ In the dialogue he emphasises that Nestor's life

\footnotetext{
${ }^{122}$ Stanley (1993) 51. For other instances where Nestor's advice is praised as being consistently true, right, and fitting see Hom. Il. 2.440-44, 7.371-3, 8.166. See also Dickson (1995) 10.

${ }^{123}$ Roisman (2005) 17. Roisman unpacks the complexities of Nestor's role in the Iliad. See also Fortenbaugh (1992); Dickson (1995) 10.

${ }^{124}$ Dickson (1995) 10.

${ }^{125}$ Dickson (1995) 105.

126 Translation by Fowler (1936).

${ }^{127}$ Powell (1988) 27-30; 269-71 argues that both Plutarch and Cicero derive their material from a common Hellenistic philosophical tradition. We know from titles preserved by Diogenes Laertius that many Hellenistic philosophers were interested in the topic of old age and it was "clearly established in the tradition well before Cicero's time". On old age in philosophical writing before Cicero see Powell (1988) 24-27; for after Cicero see 27-30.
} 
experience and ability to convey his good judgement eloquently make him more desirable to Agamemnon than even Ajax, the strongest of the Achaeans (Cic. Sen. 31). Cicero's Cato evokes this example within the dialogue to make a case for his civic value as an 84-year-old. Though no longer physically strong, as he was when military tribune at Thermopylae, his mind is more vigorous than ever before and the Senate and people of Rome recognize his pre-eminence as an advisor (Cic. Sen. 32-33). Cicero here is using the exempla of both Nestor and Cato within De Senectute to fashion his own old age. ${ }^{128}$ He illustrates that the elderly could still play an essential role in the management of the state, even in political crisis. ${ }^{129}$ And, by doing so, he reinforces his own decision to "cast off the guise of retired elder statesman" and take an active role in the imminent fight for the Republic. ${ }^{130}$ Indeed, it is his old age and tested prudence which makes him the ideal leader. Thus, a senex who lacked both military support and an official office, Cicero's best chance at securing power after Caesar's death was by becoming an unquestioned figure of sagacity and counsel, not simply to Dolabella, but to all of Rome's younger leaders. With Nestor as his paradigm, the statesman relies on his own longevity, practical wisdom, and past greatness to establish fresh authority as mentor within his correspondence.

\section{The Experienced Statesman}

Because "experience is the fruit of years" Cicero first and foremost draws heavily on his status as a senex to illustrate his rich political career and position himself as a sage advice-giver (Arist. Eth. Nic. 6.1142a6). Certainly, Roman society valued age. Respect for elders was deeply entrenched in their veneration of the mos maiorum and the notion that senes had earned auctoritas and dignitas through experience. ${ }^{131}$ Old age came to be regarded as the period when "consciousness of a life well spent and the memory of many deeds worthily performed" made one

\footnotetext{
${ }^{128}$ Lämmle (2017) 28-34 examines De Senectute and its status as a 'swan-song'

${ }^{129}$ Zarecki (2014) 137-8.

130 Zarecki (2014) 137-8.

${ }^{131}$ Cokayne (2003) 20-21. That the Romans valued old age is also attested in institutions such as the cursus honorum which stipulated minimum age requirements for its various magisterial offices; see Harlow \& Laurence (2001) 104-16. Likewise, the tradition of displaying imagines maiorum is illustrative of the veneration of elderly ancestors; see Flower (1996). On perceptions of old age in ancient societies in general, see Falkner (1989) 23-33.
} 
intensely well-reasoned (Cic. Sen. 3.9). ${ }^{132}$ Only those who, for decades, had lived virtuously and committed themselves to the disciplined absorption of experience could claim proper understanding of the world around them. It was this highly cultivated wisdom which meant the elderly could still meaningfully contribute to society, largely by way of teaching and counselling. ${ }^{133}$ Though Cicero could not boast Nestor's legendary longevity, he was sixty-two years old at the time of Caesar's death. This firmly marked him as a senex who had entered the final stage of the life course. ${ }^{134}$ Indeed, other than himself, only three men who held the consulship either during or prior to the year $63 \mathrm{BC}$ are known to still have been living in $44 \mathrm{BC}$ : L. Aurelius Cotta (cos. 65 BC), L. Julius Caesar (cos. 64 BC), and C. Antonius Hybrida (cos. 63 BC). ${ }^{135}$ As one of Rome's oldest consulars, then, Cicero somewhat paralleled Nestor as a sole remaining representative of times gone by. ${ }^{136}$ His forty-years of service to the state meant he was wellpositioned to use his age and subsequent political experience to cast himself as an authority on the current crisis.

Take, for instance, his letter to Cornificius in October $44 \mathrm{BC}$. While writing to the Caesarian to offer encouragement and to advise him against acquiescing to the mounting Antonian threat, the statesman commented

I often feel sorry for you, because you are too young to have sampled any part of a free commonwealth in sound working order. Formerly it was at least possible to hope, but now even that has been torn from us (Fam. 12.23.3). ${ }^{137}$

Immediately noticeable here are the echoes of Nestor's appeal in book one of the Iliad. Cicero, like the Homeric elder, creates a generational divide by identifying his addressee as being too

${ }_{132}^{132}$ Cokayne (2003) 91, 95-96. See also Cic. Off. 1.153-4.

${ }^{133}$ Cokayne (2003) 91.

${ }^{134}$ Harlow \& Laurence (2001) 118. The age at which a man becomes a senex has been noted to start anywhere between forty-six and sixty. Suder (1978) 5-8 gives a comprehensive analysis of the ancient sources.

${ }^{135}$ Zarecki (2014) 137. n 15.

${ }^{136}$ Falkner (1989) 31.

${ }^{137}$ Cornificius at the time was facing an intense crisis. Having been appointed governor of Africa Vetus in the Summer of $44 \mathrm{BC}$, he now refused to relinquish his province to C. Calvisius, the man whom Antony had selected to replace him. As a result, there was increasing tension between himself and the Antonian forces. See entry for 'Quintus Cornificius' in Oxford Classical Dictionary, 401. 
young to remember particular past events. ${ }^{138}$ This has the instant effect of tipping the balance of power in Cicero's favour, casting him as the senior party in the exchange. Notably, he is employing a crucial component of phronesis: memory. As a virtue to which only the elderly can aspire, phronesis is founded on the ability to remember unique past experiences and use this knowledge to inform present decision-making (Cic. Inv. rhet. 2.160). ${ }^{139}$ Indeed, the author of the Rhetorica ad Herennium relays that "a well-furnished memory, or experience in diverse matters, is termed Wisdom" (Rhet. Her. 3.2.3). ${ }^{140}$ In his letter Cicero offers sympathy to Cornificius on account of his insufficient memory. The younger addressee unfortunately cannot recall a time when the Republic was functioning and has never had the pleasure of experiencing true libertas first-hand. The implication, however, is that Cicero has. Unlike Cornificius, the elder can recall an almost mythical era when hopes were high and the res publica, unmarred by political crisis and war, operated as it ought. Though his act of remembrance here is far more implicit than Nestor's lengthy digression, it nonetheless illustrates that Cicero has a "privileged knowledge of the past". ${ }^{141}$ This unique understanding marks him as a senex whose experience and practical wisdom is necessarily superior to that of Cornificius. ${ }^{142}$ Cicero's advice on present matters, therefore, must be highly valuable to his addressee.

In a letter to Brutus Cicero similarly establishes authority "based on his ability to remember and remind". ${ }^{143}$ Cicero, unimpressed by Brutus' apparent clemency, urges him to adopt a hardened stance against the Caesarians. As part of his appeal he draws on his own memories of past political crises, writing

Of all the civil wars in our commonwealth that I remember there has not been one in which the prospect of some form of constitution did not exist whichever side won. In this war I should not like to be positive about what constitution we shall have if we win, but

\footnotetext{
${ }^{138}$ Martin (1989) 80.

139 Aubert-Baillot (2015) 73.

140 Translation by Caplan (1954). Aubert-Baillot (2015) 73.

${ }^{141}$ Dickson (1995) 105. Dickson here is referring to Nestor's own knowledge of the distant past.

${ }^{142}$ Falkner (1989) 31 relays that the act of recall allows one to provide "explicit arguments for continued self-value".

143 Martin (1989) 80.
} 
there will certainly be none ever again if we lose. Accordingly, I propose stern measures against Antony and against Lepidus too (ad Brut. 1.15.10).

Once again, Cicero emphasises his status as an experienced statesman by demonstrating superior knowledge of past events. In this case the object of his reminiscence is civil war. Born in $106 \mathrm{BC}$, Cicero had certainly experienced his share of civil strife. His first encounter with conflict was at the age of sixteen when he was enlisted to fight against the socii in revolt in the Social War of 9188 BC. ${ }^{144}$ Cicero returned, however, to an even greater crisis. Sulla had marched his veterans on Rome in order to seize back the power that Marius had stripped from him (Plut. Vit. Sull. 7.1-8.4, Vit. Mar. 34.1-2). Civil war wracked the city for the next eight years. ${ }^{145}$ Though Cicero himself did not take an active role in either of these Sullan conflicts, they were nonetheless events which he had experienced first-hand. The same, however, cannot be said for Brutus, who was likely born in 85 BC. ${ }^{146}$ Some twenty years Cicero's junior, his prior experience with civil war extended only to that between Caesar and Pompey in 49-45 BC (Plut. Vit. Brut. 4.1-5). By highlighting his capacity to recall more than one civil conflict, Cicero here draws attention to Brutus' relative inexperience. At the same time, using this superior knowledge of the past, he legitimizes his own authority as a political counsellor in the present. ${ }^{147}$ The statesman recognizes that the war against Antony is unlike any he has experienced before; this time, should they fail, any hope of restoring the res publica will be permanently lost. Armed with this wisdom, Cicero is able to exercise phronesis and arrive at a well-reasoned decision. ${ }^{148}$ He determines that the best course of action for Brutus to take against their adversaries is one, not of mercy, but of severity. Because it is anchored in personal experience, Brutus can rest assured that this counsel is informed by the

\footnotetext{
${ }^{144} \mathrm{He}$ fought under Pompeius Strabo, and later under Sulla, before leaving the army at the war's conclusion to resume to his studies in Rome.

${ }^{145}$ For an account of the conflicts between Sulla and Marius see Plut. Vit. Sull. 7.1-8.4, Vit. Mar. 34.1-44.6; Tempest (2014) 27-9.

${ }^{146}$ Clarke (1981) 11.

${ }^{147}$ Martin (1989) 80 notes that recall always serves an "exterior goal", it is never carried out merely for the simple pleasure of reminiscence.

${ }^{148}$ Sattler (1947) 58-9 defines phronesis as "that sagacity which enables a man to find means to an end" by way of experience and deliberation.
} 
"fullest possible knowledge" and must surely take it into consideration when planning his next move. ${ }^{149}$

Finally, the past experience to which Cicero most noticeably turns is that of his consulship in 63 BC. During his time as Consul he had famously suppressed the second Catilinarian conspiracy with "vigilance, circumspection, and courage". ${ }^{150}$ It was an act widely regarded as his greatest triumph and an impressive display of Cicero's political intelligence. ${ }^{151}$ Indeed, the statesman himself claimed that, by delivering the Catilinarians, he had single-handedly saved the Republic (Cic. Cat. 3.2-3; Sull. 33; Phil. 6.17-8, 14.14). ${ }^{152}$ Where Nestor recalls his tremendous battle against the Centaurs to signal his present-day authority, Cicero reminisces about his own thwarting of Catiline and the pre-eminence he earned as Rome's protector. These acts of recall manifest in a number of ways within the correspondence. In some cases, Cicero simply alludes to the great service of "good faith, vigilance, [and] patriotism" which he performed for his country as consul (ad Brut. 2.1.2). So too does he remember "the days of my greatness" when "my name stood high" throughout the city (Att. 15.5.1-2). External parties similarly recall the statesman's heroism. Using direct speech, Cicero quotes for Dolabella a conversation he had with L. Julius Caesar. Lucius purportedly remarked that Cicero and Dolabella were the only two men in Rome who, because of their noble actions, genuinely deserved the title of Consul (Fam. 9.14.3). Though no doubt a fulsome attempt to flatter his correspondent, this direct quote nonetheless lends verisimilitude to Cicero's own claim to superiority on account of his successful consulship. ${ }^{153}$ Importantly, Octavian even went as far as to beseech him to "save the Republic a second time" (Att. 16.11.6). ${ }^{154}$ Cicero asserts that this is a plea echoed by his entire community (Cic. Phil. 6.2).

\footnotetext{
${ }^{149}$ Mitchell (1991) 18.

${ }^{150}$ Habicht (1990) 31.

151 Santangelo (2013) 59.

${ }^{152}$ Cicero's consulship and his status as the saviour of the Republic receives a more exhaustive examination in Chapter Three.

${ }^{153}$ Hutchinson (1998) 113-6 relays that Cicero only uses dialogue when there is something "worthy of report". Likewise, he notes dialogue (when not in a letter to Atticus) is almost always used to lend verisimilitude to a claim.

${ }^{154}$ Notably, Cicero recognizes that Octavian's comment was simply an attempt at flattery, one which had "ruffled his feathers" according to Hall (2009) 182-3. See also Hall (2013) 223-4.
} 
The people of Rome recognize the triumph that was his consulship and implore him once again to play the role of protector in his "old style" (Fam. 12.24.2).

As we have seen, the most essential component of phronesis is possession of practical knowledge acquired as a result of experience in a specific field. ${ }^{155}$ By recalling (or having others recall) his heroic consulship, the elderly Cicero is using self-promotional rhetoric to communicate superior experience in matters of libertas and the res publica. ${ }^{156}$ Having already defended the commonwealth once, he "trades on his old reputation (...) for auctoritas in a new world" and becomes the authority to whom younger generals must turn for advice if the Republic is to survive this second crisis. ${ }^{157}$ Just as Nestor's digressions establish the validity of his position as wise counsellor to the more engaged youth, so too do Cicero's acts of reminiscence. ${ }^{158}$ What is more, through repeated allusions to his commendable past deeds, Cicero "creates the impression of excellence and exemplarity". ${ }^{159}$ Many have understood this self-praise to be an expression of conceit or arrogance. Cassius Dio called him "the greatest boaster alive" (Cass. Dio. 38.12.7) and a number of scholars concur with the sentiment. ${ }^{160}$ Nevertheless, Cicero saw it otherwise. In De Senectute, his interlocutor Cato observed that Nestor, time and again, "proclaimed his own merits" yet did not fear accusations of arrogance or loquaciousness (Cic. Sen. 31). This is because his self-praise was never conceived with vain intent. Rather, the tales of his past excellence were intended to provoke his younger audience and challenge them to fulfil the heroic ideal that he himself embodied. ${ }^{161}$ The same goes for Cicero. Within the correspondence he repeatedly highlights his consular dignitas and the superior auctoritas he acquired in saving the Republic.

\footnotetext{
${ }^{155}$ Hellegouarc'h (1972) 257.

${ }^{156}$ Hall (2013) 223.

${ }^{157}$ This sentiment is best observed in Phil. 6.17 when Cicero remarks "who has more experience [than me]? For I have been waging war against treacherous citizens for twenty years". Translation by Shackleton Bailey (2010).

${ }^{158}$ Austin (2003) 301.

${ }^{159}$ Blom (2010) 287.

160 Translation by Cary (1914). Scholars who tend to agree include Syme (1939) 143-5; Shackleton Bailey (1971) 34. See Blom (2010) 287. n. 2.

161 Austin (2003) 301. This is not to say that conceit had no place in Roman Republican politics. Because character was a "measure of worth" in Roman society, shyness was counterproductive. See also May (1988) 42. n. 87; Allen (1954); Kennedy (1972) 101.
} 
By doing so, Cicero establishes himself as a noble exemplum for the younger statesmen. ${ }^{162} \mathrm{He}$ promotes his valiant and sustained opposition to Catiline as the ideal model on which to base the assault against Antony. ${ }^{163}$ In setting this example, Cicero, without the need for military might or official authority, encourages his addressees to defend the res publica with unrelenting vigour just as he had years before.

Cicero certainly sought to fashion a relationship with Dolabella within this framework and act as his model for imitation. Should he be made receptive to Cicero's counsel, as one of the three "centres of energy" in Rome at the time, the young statesman would make a powerful weapon against Antony. ${ }^{164}$ Several weeks after stepping into the consulship in March 44 BC, Dolabella had successfully quelled riots instigated by Caesar's supporters; an altar commemorating the dictator was destroyed in the process. ${ }^{165}$ Cicero understood this to be a crucial victory against the rising Caesarian threat and wrote to the younger man to congratulate him on his success. ${ }^{166}$ Somewhat ambitiously he reports that

[many people have] expressed deep gratitude to me, not doubting, so they say, that it is in conformity with my precepts and advice that you are showing yourself so admirable a citizen and so outstanding a Consul (...) As for me, it is a proud thing that a young consul should win such laurels as, so to speak, a pupil from my school (Fam. 9.14.1).

Here, in no uncertain terms, Cicero casts himself as the wise counsellor responsible for Dolabella's achievements as Consul. His addressee is characterised as a loyal student who shares in his teacher's political aspirations and subsequently uses his authority to put these "high-minded ideals of government" into practice. ${ }^{167}$ Within this framework, any glory that Dolabella earns when acting on the elder's guidance is ultimately reflected back onto Cicero as the advice-giver. ${ }^{168}$

\footnotetext{
162 Blom (2010) 270; Burnand (2000) 192.

${ }^{163}$ Burnand (2000) 189.

${ }^{164}$ Frisch (1946) 76. The other two centres of energy at this time were of course Antony and Octavian.

${ }^{165}$ Hall (2009) 183.

${ }^{166}$ Hall (2009) 183-4; Lintott (2008) 345.

${ }^{167}$ Hall (2009) 185.

${ }^{168}$ Lintott (2008) 345.
} 
It is in this same letter that Cicero becomes the Nestor to Dolabella's Agamemnon (Fam. 9.14.2). Jon Hall notes that this casting was likely an attempt to navigate any offence the younger correspondent may have taken to being styled as Cicero's pupil. ${ }^{169}$ To be likened to Agamemnon in any other context is surely the highest of compliments. Only, when juxtaposed against the legendary figure of Nestor, it served to further highlight Cicero's position of power over his addressee as an experienced senex and consular. Though he later promises Dolabella that all has been said in jest, the letter nonetheless is an important representation of Cicero's post-Ides vision (Fam. 9.14.4). To steer the Republic by counselling others and receive in return the utmost praise is the elder's ideal position. ${ }^{170}$ It is a role he can secure through the consistent demonstration of phronesis. By emphasising his old age and extensive past experience, Cicero establishes a noble and authoritative ethos with which to dispense advice and influence the actions of his younger correspondents. ${ }^{171}$

\section{The Prophet}

It is in his De Officiis that Cicero identifies prudentia as the Latin equivalent of phronesis (Cic. Off. 1.153). Like its Greek counterpart, prudentia is an intellectual virtue which connotes good sense, practical wisdom, and intelligence. Importantly, it finds its etymological roots in providere, 'to see ahead'. ${ }^{172}$ That Cicero recognized this association is evident in his definition of prudentia; he lists memoria, intellegentia, and providentia as its three parts (Cic. Inv. rhet. 2.160). Memoria concerns the past, intellegentia relates to present understanding, and providentia is one's capacity to predict future events before they occur (Cic. Inv. rhet. 2.160). It is this power of foresight which is the final critical element in Cicero's self-fashioning as a sage advice-giver. If one demonstrates that they can accurately divine future outcomes, their counsel must naturally be perceived as invaluable. Thus, in order to secure fresh authority as an advisor, the statesman establishes himself as a prophet-like figure within the correspondence. Already in $46 \mathrm{BC}$, Cicero

\footnotetext{
169 Hall (2009) 185.

170 Blom (2010) 135.

${ }^{171}$ Unfortunately for Cicero, his efforts with Dolabella would prove unsuccessful. See Cic. Phil. 11.5; Ad Brut. 13.1.

172 Santangelo (2013) 57; Aubert-Baillot (2015) 69; White (2010) 123; Hellegouarc'h (1972) 256.
} 
had expressed to Aulus Caecina that he had gained "prophetic skill" by "assiduous theoretical study" and "my long experience as a statesman and the remarkable vicissitudes of my career" (Fam. 6.6.3-4) ${ }^{173}$ His farsightedness is the product of intellect honed by "broad learning" and decades of political involvement. ${ }^{174}$ Like he employs his past experience to validate his present authority as an expert advisor, Cicero uses this implied insight to convey an ability to "evaluate accurately the course of future events". ${ }^{175}$

Take, for instance, his letter to Brutus in April 43. Not for the first time, Cicero implores Brutus to understand that mercy has no place in a civil war. He instead urges a path of "salutary severity" and ends by adding

Believe me, Brutus, you and your friends will be overwhelmed if you do not take care. You will not always have a people and a Senate and a leader of the Senate as they are today. You may take this as a Delphic oracle. Nothing can be more true (ad Brut. 1.2a.2$3)$.

In suggesting that his words carry the same force as a pronouncement from the Pythia, Cicero here is fashioning himself as a kind of prophet. He equates his implicit superior knowledge and experience with an ability to foresee any potential implications of Brutus' actions (or rather inaction). ${ }^{176}$ Consequently, the statesman is able to reveal the most advantageous path for his correspondent to take in order to secure success. Cicero's prediction is clear. If Brutus and the Liberators do not pursue a course of pre-emptive aggression where Antony is concerned, their endeavour to free Rome will fail. Even Decimus recognized Cicero's unique gift. He wrote to the orator in the wake of the Battle of Mutina, beseeching him to exercise his foresight to ensure that the death of both Hirtius and Pansa would not give rise to hope among the Antonians (Fam.

\footnotetext{
${ }^{173}$ As proof, Cicero lists some of the successful predictions he has made. He states that had foreseen the civil war between Pompey and Caesar. Likewise, Cicero assures Caecina that no civil war would have taken place had Pompey taken Cicero's advice and gone to Spain (Fam. 6.6.4-5). On Fam. 6.6 and the concept of divinatio within it see Santangelo (2013) 47-55.

${ }^{174}$ Mitchell (1991) 19.

175 Mitchell (1991) 18-19.

${ }^{176}$ Aubert-Baillot (2015) 76-9; Mitchell (1991) 18-19.
} 
11.9.1). In projecting this oracular ethos, Cicero secures increased authority as a voice of counsel. He recognized that people tend to have more confidence in those who they believe are more knowledgeable than themselves (Cic. Off. 2.23). An exclusive understanding of the future, "even to its most distant possibilities", firmly places Cicero in this category and provides him with the auctoritas necessary to influence the actions of others (Att. 10.8.7) ${ }^{177}$ Brutus, then, would be unwise to ignore Cicero's oracle.

Unfortunately, on the Ides of March, he had done just that. In a letter to Atticus on April $1944 \mathrm{BC}$, Cicero expresses great anguish at the conspirators' failure to heed his advice:

Do you remember how that first day on the Capitol I cried out that the Senate ought to be summoned to the spot by the Praetors? Great heavens, what might have been accomplished then amid the rejoicing of all honest men, even the moderately honest, and the discomfiture of the bandits! (Att. 14.10.1).

The statesman demonstrates that he had attempted to exercise his oracular ethos in the hours following the assassination. With his gift of foresight, Cicero recognized that the Liberators could consolidate their position of authority by calling an immediate senate-meeting. His prophecy, however, fell on deaf ears and left an opening which Antony used to his own advantage. ${ }^{178}$ This episode is again mentioned in Att. 15.11. Cicero recreates for Atticus the meeting between himself and the conspirators at Antium (Att. 15.11.1-2). Though he offered advice on the matter of their next move, Cicero pointedly made it known that they should have accepted his counsel back when he had offered it on the Ides. That is, Brutus and Cassius ought to have "summoned the Senate, urged the popular enthusiasm with greater vigour, and assumed leadership of the whole Commonwealth" (Att. 15.11.2). ${ }^{179}$ Instead, their failure to act in accordance with his guidance meant Antony succeeded in securing critical early support. Here, because the two younger

\footnotetext{
${ }^{177}$ Hellegouarc'h (1972) 257. Cicero is quoting Thucydides' praise of Themistocles (1.138.3). The Greek historian believed Themistocles was "at once the best judge in those sudden crises (...) and the best prophet of the future, even to its most distant possibilities". See White (2010) 123.

${ }^{178}$ See the Introduction for Antony's role in the 17 March Amnesty and Caesar's funeral.

179 in ad Brut. 2.1.1 Cicero similarly laments the Liberators' tendency to procrastinate and delay in carrying out important measures.
} 
statesman had failed to accept the elder statesman's advice, when events unfolded poorly, Cicero subsequently earned the right to criticize their actions. ${ }^{180}$ In fact, Peter White notes that "criticism can be viewed as a kind of advice after the event". ${ }^{181} \mathrm{He}$ reprimands the Liberators for disregarding his counsel and, in doing so, validates his own prophetic self-positioning. Bad outcomes occur when Cicero's oracles are ignored. His power of foresight, therefore, must be potent and any advice he gives warrants consideration at the very least. ${ }^{182}$

Even worse than electing not to accept Cicero's sage counsel is failing to seek it in the first place. Brutus and his followers deliberately chose not to involve the elder in their conspiracy. ${ }^{183}$ Had they consulted the self-proclaimed oracle, Cicero likely would have offered a simple, yet critical piece of advice: kill Antony. It is this missed opportunity for which Cicero most strongly criticises his correspondents. His letter to Trebonius, for example, reads

How I wish you had invited me to that splendid feast on the Ides of March! We should then have had no leftovers! As it is, we are having so much trouble with these that the immortal service which you and your friends rendered the commonwealth leaves room for some criticism (Fam. 10.28.1).

The statesman expresses similar sentiments to Brutus, Cassius, and Atticus (ad Brut. 2.1.1, 2.5.2; Fam. 12.4.1; Att. 15.11.2. 15.20.2). Though the Liberators' act had been a noble one, they had made a fundamental miscalculation in leaving Antony alive. This oversight could have been avoided, Cicero explains, if only he had been given the opportunity to offer his wisdom. The implication is that the elder had prophesised Antony's rise to power. His decades of political experience have provided him with a unique kind of practical knowledge; the ability to foresee the paths which should be followed and those which must be avoided. ${ }^{184}$ As a result, he is wellpositioned to effectively predict the future movements of Rome's leading statesmen and use this

\footnotetext{
${ }^{180}$ White (2010) 128.

181 White (2010) 128.

${ }^{182}$ In fairness, Servilia did openly sneer at Cicero's criticisms in Att. 15.11.2.

${ }^{183}$ Lintott (2008) 339. See also Plut. Vit. Cic. 42.

184 Santangelo (2013) 58.
} 
wisdom to benefit the res publica. ${ }^{185}$ Indeed, Cornelius Nepos, having poured over the correspondence, affirmed the orator's prophetic abilities. He wrote that

Cicero's foresight was almost divination. For he not only predicted the events that actually happened during his lifetime, but, like a seer, foretold those which are now being experienced (Nep. Att. 16.4). ${ }^{186}$

Unfortunately, however, because the Liberators had not sought out his counsel, Cicero could not exercise his prudentia, Antony remained alive, and the state now suffers the consequences. Such is the orator's criticism of his correspondents. It is again this use of censure which works to solidify his oracular ethos. Cicero demonstrates that he possesses an unprecedented understanding of future outcomes and, as such, must be taken seriously as an advice-giver. Failure to consult him before taking action will ultimately have a negative impact on the entire community.

\section{The Passive Senex}

Just as phronesis allowed Cicero to establish authority as an advice-giver, he employs these same themes of aged wisdom to craft an ethos of withdrawal in the aftermath of Caesar's death. ${ }^{187}$ Despite the euphoria of the dictator's assassination, the Liberators, as Cicero perceived it, had quickly lost that vigour which had driven them to commit their great deed. Their carelessness and naïve lack of foresight in sparing Antony were especially troubling and Cicero found himself disillusioned by the Ides of March (Att. 14.12.1, 14.14.3,14.18.4, 14.22.2, 15.4.2-3; Fam. 12.4.1, 10.28.1; ad Brut. 1.15.4). ${ }^{188}$ What is more, he came to deplore the very amnesty which he had helped to establish. The preservation of Caesar's acta rendered his assassination a near pointless endeavour, for the tyrant's essence still lived on in his decrees (Att. 15.6.1; Fam. 12.1.1). ${ }^{189}$ Thus, as early as April $44 \mathrm{BC}$, Cicero was writing as though all was already lost (Att. 14.10.1). Be it out

\footnotetext{
${ }^{185}$ Santangelo (2013) 58, 180.

${ }^{186}$ Translation by Rolfe (1929). Rolfe p. 317 believes that Nepos here is exaggerating in his enthusiasm. Santangelo (2013) 178, by contrast, argues that he is clearly being serious in his praise of Cicero's prophetic talent.

${ }^{187}$ See Kenty (2020) 103- 128 for past instances of Cicero's non-authoritative self-fashioning.

${ }^{188}$ On the actions of the conspirators and Cicero's subsequent disillusionment, especially between April and August 44 BC, see e.g. Blom (2003) 290-299; Rawson (1994) 468-476; Lintott (2008) 339-350.

${ }^{189}$ More on this in Chapter Four.
} 
of fear or disenchantment, the statesman had decided he would no longer actively participate in the political game. It is this passivity which has long been subject to criticism from both ancient and modern commentators alike. David Stockton, for instance, somewhat harshly describes the image that Cicero presents in these months as being one of "vacillation, timidity, recrimination, and absence of any constructive thought". ${ }^{190}$ The situation, however, is more nuanced. Cicero's disengagement demanded the careful construction of a seasoned ethos, one which demonstrated that his old age and practical experience meant he was better placed to serve the Republic from afar.

Thus, Cicero set about positioning himself as a man too old to directly involve himself in the present crisis. He writes that "...soldiering, especially in a civil war, is not for people our age" (Att. 14.19.1) and war is "a weary business unbefitting our age" (Att. 14.13.2). ${ }^{191}$ Though the conspicuous and sustained emphasis on his seniority is certainly an attempt at self-positioning, Cicero did have a point. At sixty-two years old he was likely feeling the effects of age. Physical weakness and decreased vitality were inevitable for a man of his seniority. Indeed, it is precisely because of this perceived waning that the elderly were exempt from those public offices which require intense vigour to be executed (Cic. Sen. 35). ${ }^{192}$ Plutarch even reasons that Cicero was rejected by Brutus as a member of the conspiracy because he was at an age where one's courage, determination, and endurance is most frail (Plut. Vit. Cic. 42). The senior statesman moreover faced the problem of the superiority of military proficiency. In the twenty years since his consulship, military excellence had become the prerequisite for political success (ad Brut. 1.10.3) ${ }^{193}$ Antony, Hirtius, and Pansa, for instance, each owed their prosperous political careers to their time spent as Caesar's loyal soldiers. ${ }^{194}$ While Cicero never had a taste for war (nor did

190 Stockton (1971) p. 287. Syme (1939) 139 is likewise critical of Cicero's withdrawal. By contrast, Rawson (1994) 468-490 and Blom (2003) 290-299 are more neutral in their examination of Cicero's passivity. See also Blom (2003) 54 n. 22.

${ }^{191}$ Cicero expresses similar sentiments in a number of other letters between April and August 44 BC. See e.g. Att. 14.13.2, 14.19.1, 14.21.3-4, 14.22.2, 15.1.4, 16.3.4, 16.7.7; ad Brut. 1.10.15, 1.2a.3.

${ }^{192}$ Harlow \& Laurence (2002) 122. Between sixty and sixty-five was the age at which a man could be freed from obligations such as jury service and attendance at the senate, see Cokayne (2003) 1.

193 Zarecki (2014) 137-8.

${ }^{194}$ Zarecki (2014) 137. 
he ever profess military prowess) now, on account of his old age, he certainly had no hope of competing with Antony's martial superiority. ${ }^{195}$ Nor did he wish to (Att. 14.13.2, 14.21.3-4, 14.22.2).

Rather, Cicero used his elderly ethos to shift the burden of political unrest onto Rome's younger leaders. We see this clearly in a letter to Brutus. On the cusp of an argument with his correspondent about the ineffectiveness of mercy in a civil war, Cicero stops himself. Instead, he offers Brutus a quote from Plautus' Trinummus, writing plainly “My time is nearly over. You're the party most concerned" (ad Brut. 1.2a.3). ${ }^{196}$ Cicero's message here is clear. The responsibility of preserving the future Republic rests with those who will still be alive to see it. Though he does not deny that a war must be had in order to secure this future libertas, he simply does not regard it as his to fight. ${ }^{197}$ It is his desire, so Andrew Lintott put it, to become a "passionate spectator". ${ }^{198}$ Cicero relays a similar message to Atticus, explaining "Old age is making me more cantankerous, everything irritates me. But I have had my time. Let the young men worry" (Att. 14.21.3). Such self-positioning draws on one of the key themes of Cicero's De Senectute, written around the same time. In it he argues that it is improper for an aging man to act in ways beyond those which his strengths and abilities allow (Cic. Sen. 27). At sixty-two years old, to directly involve himself in the affairs of a crisis-ridden state would certainly be beyond the bounds of appropriateness. Therefore, he determines, it must fall to the younger generation to perform an active role in the protection of the res publica against the Antonian threat. ${ }^{199}$ Notably, Nestor too had adopted a similar attitude. At Patroclus' funeral games, the senex again recounted his own youth and the pre-eminence he once enjoyed. "So that's the man I was", he finishes, "but now's the time for the younger men to lock in rough encounters, time for me to yield to the pains of age" (Hom. Il.

\footnotetext{
195 That Cicero preferred to keep out of the military sphere is perhaps evident in his De Re Publica. In his construction of the ideal rector, nowhere does Cicero include military excellence as a defining characteristic. See Zarecki (2014) 85, 92-3, 109-10, 154, 160.

${ }^{196}$ The dialogue is spoken by Philto, a senex and the father of Lysiteles. See Shackleton Bailey (2004) p. 231.

${ }^{197}$ Leber (2015) 32.

${ }^{198}$ Lintott (2008) 339. See also Zarecki (2014) 135.

${ }^{199}$ Blom (2003) 265. This epistolary self-positioning is re-enforced by physical absence. Cicero left Rome in early April under the pretence of touring his country estates and did not return until August 31, two days before delivering the First Philippic. See Leber (2015) 32.
} 
23.716-18). ${ }^{200}$ Cicero, then, is not being unreasonable in wanting to take on a more passive role; his policy of aged withdrawal remains consistent with his construction of a Nestor-like persona. By emphasising his old age within the correspondence, the statesman rationalises his absence from the political sphere and transfers responsibility without compromising his already fragile authority over the younger generation.

However, it would not do for Cicero, in his withdrawal, to simply sit back and "bask in the glory if a lifetime fulfilled". ${ }^{201}$ Though Antony posited that the elder statesman should much prefer to spend his last years in tranquillity than surrounded by anxiety, mere rest and relaxation was widely regarded as a disgraceful self-indulgence among the Romans (Att. 14.13a.3). It was unsuitable for an old man to retire completely to domesticity because his experience, wisdom, and good sense are precisely the qualities which rendered him so well-equipped for public service (Plut. Mor. An seni. 785e). ${ }^{202}$ As such, Cicero needed to position himself as one who was carrying out cum dignitate otium - leisure with dignity. ${ }^{203}$ This was an ideal state of idleness to which every helmsman of the res publica strived (Cic. Sest. 98; Fam. 1.9.21). It involved devoting one's free time to the pursuit of literature, rhetoric, and philosophy in order to serve the Republic and better her citizen body while maintaining distance from the political arena. ${ }^{204}$ A letter to Atticus sheds some light on Cicero's own intent to retire nobly. Playing on a line from book five of the Iliad, he tells Atticus

[war] is a weary business unbefitting our age (...) I might say to you and you to me "my child, the works of war are not for you. Let your concern be works of worded joy' (Att. $14.13 .2) \cdot{ }^{205}$

\footnotetext{
200 Translation by Fagles (1998).

${ }^{201}$ Harlow \& Laurence (2002) 121. See also Cokayne (2003) 111.

${ }^{202}$ Harlow \& Laurence (2002) 123.

${ }^{203}$ For cum dignitate otium see e.g. Baraz (2010) 14. n.3; Lintott (2008) p. 215; Hanchey (2013) 180-196.

204 The Elder Scipio, for instance, was greatly admired by Cicero for how he carried out his otium with dignity (Cic. Off. 3.1-4). See Baraz (2012) 190; Hanchey (2013) 197; Blom (2010) 269-70.

${ }^{205}$ Cicero here plays on a quote from Hom. Il. 5.428. See Shackleton Bailey (1967) 226.
} 
Once again, the statesman exploits his old age to craft an ethos of withdrawal. On this occasion, however, he reveals that he does not wish to remain dormant in his passivity. Rather, he intends to dedicate his idleness to literary pursuits. By doing so, Cicero can navigate possible accusations of self-indulgence and demonstrate that, even though he is away from Rome, he is still committed to bettering the post-Ides Republic.

Philosophy in particular was regarded by Cicero as the only undertaking outside the state that was truly dignum for it served the well-being of the Republic (Cic. Div. 2.2.6-7) ${ }^{206} \mathrm{He}$ believed that, by producing philosophical treatises, one could educate men about ethics and wisdom. This in turn influenced their relationship to the res publica and transformed them into "loyal citizens of a Ciceronian bent, thus improving the condition of the state". ${ }^{207}$ As such, while in his period of post-Ides otium, Cicero completed six philosophical works-De Divinatione, De Fato, De Senectute, De Amicitia, Topica, and De Officiis. At first, these intellectual pursuits appear to have simply provided Cicero much needed solace in his time of uncertainty; he expresses a "profound thankfulness" for philosophy's ability to divert him from worries (Fam. 12.23.4). ${ }^{208}$ In keeping with the notion of cum dignitate otium, however, it was vital for Cicero demonstrate that his withdrawal into philosophical inquiry was not mere passive recreation. He needed to communicate that it was in his role as a writer that he could best serve the Republic in its time of crisis. Thus, in his correspondence Cicero presents philosophy as his new weapon "against the assaults of fortune" (Fam. 12.23.4). Twice he uses martial language to describe the way in which he has constructed garrisons of wisdom and armed himself with philosophy (Fam. 16.23.2, 12.23.4). To Atticus as well the statesman emphasises that prudence and reason are the only tools with which to withstand attacks on state (Att. 14.13.3). The effect of this is two-fold. First, by employing "ennobling themes of intellectual inquiry and scholarly equanimity", Cicero is able to maintain an ethos in possession of wisdom and intelligence during his period of

\footnotetext{
${ }^{206}$ Baraz (2012) 190.

${ }^{207}$ Baraz (2012) 46-7.

${ }^{208}$ On philosophy as a cure devised to lessen Cicero's misery see Baraz (2012) 86-95. See also Tempest (2014) 178.
} 
absence. ${ }^{209}$ This display of phronesis reassured his correspondents that he continued to be a wellreasoned figure on whom they could rely for sound advice. More importantly, however, Cicero casts philosophy as "a potentially powerful tool capable of restoring the Republic to a state of political health". ${ }^{210}$ It therefore follows that, by pursuing philosophy, Cicero is not withdrawing from Rome but equipping himself to be the protector of libertas. He heroizes his departure from the public eye by characterising otium and philosophical inquiry as a substitute for active political engagement. ${ }^{211}$ The result is an ethos of authority even in absence.

\section{Summary}

That phronesis — practical wisdom, good sense, prudence — plays a fundamental role in Cicero's epistolary construction of self is perhaps best encapsulated in his letter to Brutus.

My dear Brutus, I have done for our country all that lies with one who stands where I, by judgement of Senate and People, stand today. I have not only given all that I suppose can fairly be demanded of an ordinary man: good faith, vigilance, patriotism; for these are what it is everybody's duty to render. But I conceive that something more is required of one whose voice is heard among leading statesmen, namely wisdom (Ad Brut. 2.1.2).

Wisdom, more so than any other virtue or rank, is what validates Cicero's fresh position of authority in a post-Caesar society. Rather than anchor his influence in military proficiency or an official magistracy, the elder statesman sought to steer the Republic by dispensing sage advice and becoming a model for imitation. To achieve such an image demands the demonstration of Nestor-like phronesis. That is, exhibiting privileged knowledge of the past and the capacity to predict future outcomes produces a credible and authoritative ethos. With this ethos, Cicero legitimizes his advice in the present and works to ensure his younger, less experienced correspondents are more receptive to counsel. At the same time, the now sixty-two-year-old had

\footnotetext{
209 Dugan (2005) 149.

${ }^{210}$ Baraz (2012) 87.

211 Indeed, he says as much in De Divinatione 2.2.7. See also Baraz (2012) 188; Hanchey (2013) 172; Dugan (2005) 149; Tempest (2014) 177.
} 
lost faith in his young champions and sought a more passive role between March and late August $44 \mathrm{BC}$. In order to withdraw from the public sphere, he manipulates the same phronetic themes of seasoned wisdom and experience to exchange his political persona for that of a philosopher. Such nuanced epistolary self-fashioning permits Cicero to maintain an image of esteem while transferring responsibility for the res publica onto Rome's younger leaders. 


\section{Chapter Two}

\section{Eunoia: Cicero as Amicus}

... at this time I thought I ought to advise you of my affection rather than advertise my wisdom (Fam. 10.3.4).

Though of course phronesis had its place, because personal connection counted for much more than ideology in the Roman Republic, an ethos rooted in benevolence, goodwill, and generosity would prove vital to Cicero in the wake of Caesar's assassination. ${ }^{212}$ Uniting the fractured Senate against Antony called for the diligent forging of alliances and the curation of a network of amici upon whom he could rely for aid. ${ }^{213}$ In order to secure these connections, however, Cicero first needed to cast himself as an amicus. He had to demonstrate that his feelings of friendship for his addressee were founded on genuine affection, goodwill, the reciprocal recognition of merits, and, above all, a desire to render his services (Cic. Amic. 15, 20, 27, 56-61, 65-6, 74). ${ }^{214}$ Here, it is eunoia that facilitates this self-fashioning. Eunoia, simply put, is the mutual goodwill that a rhetor establishes between himself and his audience. As noted in the introduction, Aristotle locates it within the broader framework of philia and emphasises that friendship without the exchange of goodwill is not one that can be considered genuine (Arist. Eth. Nic. 9.1167a9-16; Rh. $2.1381 \mathrm{a} 4) .{ }^{215}$ It is this condition of reciprocity that makes eunoia unique from phronesis and arete. That is, to cultivate goodwill, the rhetor must actively elicit a positive emotional response from his audience. ${ }^{216} \mathrm{He}$ achieves this by characterising himself as benevolent towards, and supportive of, his listeners. Commonality too is vital. The successful orator is one who can assess the characteristics of an audience and fashion his own image in their likeness (Arist. $R h$.

\footnotetext{
212 White (2010) 10.

${ }^{213}$ Hall (2009) 183-4 highlights the importance of affiliative politeness in the forging of alliances during times of conflict. His chapter 'Politeness and Political Negotiation' is essential for understanding the role that affection, goodwill, and other aristocratic etiquette played in navigating political relationships following Caesar's death. It has been a fundamental source for this chapter.

${ }^{214}$ Brunt (1988) 352; Meyer (2000) 165.

215 Hourcade (2018) 87-88.

216 Schütrumpf (2007) 39. In this sense, it is not unlike Aristotle's theory of pathos.
} 
2.1390a16). ${ }^{217}$ Eunoia, then, goes beyond superficial goodwill and instead represents reciprocal “approval, sympathy, and readiness to help". ${ }^{218}$

Nowhere is Cicero's use of eunoia more apparent than in his correspondence with L. Munatius Plancus. As proconsul of Gallia Comata and consul-designate for $42 \mathrm{BC}$, it was essential that Cicero co-opt the younger Caesarian into his post-Ides network of amicitia. This chapter closely examines Cicero's epistolary relationship with Plancus and considers how he employs eunoia to realise this goal. In the first instance, it is on the basis of their old familial acquaintance that the statesman cultivates an impression of affection and commonality. Having known Plancus since childhood, Cicero casts himself in the role of a father and establishes a paternal eunoia between himself and his addressee. While this paternalistic benevolence certainly strengthens their bond of amicitia, it likewise acts as prelude to paternalistic criticism. Cicero expresses reservations about Plancus' past to cast him as an amicus who has somehow failed in his duty and must now redeem himself. Another important stage in the cultivation of eunoia is offering praise and approval. By recognizing and applauding Plancus' acts of patriotism, Cicero directly appeals to the Caesarian's sense of dignitas and motivates him to remain on the senatorial path. The only way to secure everlasting praise and recognition from the wider community, he reminds him, is through service to the state. Finally, Cicero concludes his programme of eunoia by demonstrating an enthusiastic willingness to support Plancus. He pledges to promote and protect the Caesarian's prestige, a promise he fulfils by securing him honours from the Senate. This act of service conveys Cicero's desire to fulfil the obligations of amicitia and form a sincere bond with Plancus. The expectation, however, is that Plancus will respond in kind. After all, genuine friendship is made manifest only by the exchange of officia. ${ }^{219}$ Ultimately, Cicero's rhetorical strategy was to gain Plancus' political support by casting himself in the role of amicus. He draws on the three fundamental facets of eunoia - unconditional affection, praise, and the will to help - in order to construct an ethos that binds addresser and addressee together in mutual obligation.

\footnotetext{
${ }^{217}$ Cherry (1988) 255.

218 Romilly (1958) 92.

${ }^{219}$ Verboven (2011) 411.
} 


\section{Eunoia and Amicitia in Roman Social Relations}

Before examining Cicero's use of eunoia in his correspondence with Plancus, a brief consideration of goodwill and reciprocal benevolence in the wider context of Roman social relations is essential. It is in benevolentia that eunoia finds its Latin equivalent (Cic. De or. 2.182; Amic. 19-20, 23, 26, 50). ${ }^{220}$ Much like its Greek counterpart, benevolentia is that mutual affection or friendliness which an orator must cultivate between himself and his audience in order to ensure a receptive disposition. ${ }^{221}$ So too is it deeply rooted in the Roman conception of friendship. According to Cicero, benevolentia is an essential condition of amicitia: "if you remove goodwill from friendship", he claims, "the very name of friendship is gone" (Cic. Amic. 19-20). ${ }^{222}$ The presence of affection and benevolence guarantees that a relationship is being sought for its own sake rather than utility (Cic. Inv. rhet. 2.167). ${ }^{223}$ At the same time, however, amicitia meant far more to a Roman statesman than mere sentiment. That is, amici were obliged to practically demonstrate their affection through the exchange of officia (Cic. Off. 2.32). These acts of service included — but were not limited to - financial backing, political support, advocacy in the Senate, and any other assistance regarding the "perils of public life". ${ }^{224}$ Any man who failed to meet these expectations risked appearing disloyal, selfish, or, worst of all, ungrateful. ${ }^{225}$ Amicitia, then, is as complex as it is distinctive. Though it is a bond which cannot exist without benevolentia and genuine affection, the complex web of expectations and obligations that such a relationship engendered made it desirable for emotionally shallow reasons as well (Cic. Inv. rhet. 2.167). ${ }^{226}$ Certainly, some friendships, such as that between Cicero and Atticus, were very intimate. "In others", writes Koenraad Verboven, "affection was more of a question of liking than loving". ${ }^{227}$

\footnotetext{
${ }^{220}$ Fortenbaugh (1988) 261. On benevolentia see also Hellegouarc'h (1963) 149-50.

${ }^{221}$ Fortenbaugh (1988) 260.

222 Translation by Falconer (1923). On amicitia see Brunt (1988); Konstan (1997); Tatum (2018) 221-2.

${ }^{223}$ Verboven (2011) 405.

${ }^{224}$ Taylor (1949) p.7; Brunt (1988) 355; Verboven (2011) 411.

${ }^{225}$ Verboven (2011) 411.

226 Verboven (2011) 412; Brunt (1988) 355.

227 Verboven (2011) 411.
} 
And in the rest, goodwill was merely an accessory to a fundamentally utilitarian exchange of favours.

It is this amalgam of reciprocal goodwill and officium which rendered amicitia essential to the social and political functioning of the res publica. ${ }^{228}$ Because the Roman state "lacked an effective institutional and administrative apparatus" with which to regulate the distribution of power and resources, personal networks of amicitia allowed statesmen to bypass official procedures and secure support for themselves. ${ }^{229}$ Romans used these webs of obligation to influence political decisions, acquire official government positions, and build a following. ${ }^{230}$ The more diverse the network, the greater the sphere of influence. Lily Ross Taylor went so far as to propose that amicitia was a direct substitute for a political party. ${ }^{231}$ Though scholars now tend to disagree with her observation, amicitia was certainly crucial to the vitality of one's political career. ${ }^{232}$ Without amici to call on for assistance, a statesman was in effect "politically impotent". ${ }^{233}$ In times of governmental crisis and civil war, then, connections counted for much more than creed. Accumulating friends on both sides of a conflict diversified one's options and greatly increased the chances of survival, especially given the tendency for individuals to switch allegiance. ${ }^{234}$ As such, the political uncertainty following Caesar's assassination meant that "the forging of alliances was a prime consideration for the leading players of the moment". ${ }^{235}$

This concern is made manifest in a letter from Trebonius to Cicero in May 44 BC. Apprehensive about the future, Trebonius attempted to "magnify his allegiance" to the statesman by engaging in incredibly fulsome correspondence (Fam. 12.16). ${ }^{236} \mathrm{He}$ sang the praises of Cicero's son Marcus (having encountered him by chance in Athens) and claimed to take great

\footnotetext{
${ }^{228}$ Verboven (2011) 414-5; Canfora (2007) 159.

${ }^{229}$ Verboven (2011) 424-5.

${ }^{230}$ Cotton (1986) offers a good discussion of this influence with regard to letters of recommendation.

231 Taylor (1949) 7

232 See Verboven (2011) 406-407 for an overview of the various critiques. It is also worth noting that political parties - as we know them — did not exist in the Roman Republic. See Tatum (2008) 26.

${ }^{233}$ Verboven (2011) 414.

${ }^{234}$ White (2010) 10

235 Hall (2009) 183.

236 White (2010) 9-10.
} 
pleasure in the young man's successes, even volunteering to take him on as a protégé (Fam. 12.16.1). Trebonius also sent Cicero some of his verses, re-engaging in a witty literary exchange they had begun a year or two prior (Fam. 12.16.3-4). The letter is carefully crafted to ensure that there exists a state of benevolence between addresser and addressee. ${ }^{237}$ This way, Trebonius can strengthen his ties to Cicero and co-opt him into his own network of amici, friends upon whom he will rely for survival in the impending civil war. Similar assertions of goodwill and friendship, what Hall has termed "affiliative politeness", are rife in the post-Ides correspondence as statesmen sought to diversify their connections. ${ }^{238}$ Benevolentia allowed them to signal their willingness to negotiate, cooperate, and even render their services. Of course, they would expect the same in return. Such is the labyrinth of goodwill, obligation, and amicitia which Cicero had to navigate in his effort to steer Plancus towards the republican cause.

\section{$\underline{\text { Recruiting Plancus }}$}

Plancus made an attractive candidate for recruitment for a number of reasons. Most obvious was his position as proconsul of Gallia Comata, a duty he took up shortly after the Ides. The office entitled him to possession of proconsular imperium and the command of three legions. ${ }^{239}$ Toward the close of $44 \mathrm{BC}$ several other figures were likewise positioned around Italy and had an army under their control: Lepidus occupied Gallia Narbonensis and Nearer Spain, Decimus took up Gallia Cisalpina (a province Antony would soon seek for himself), Pollio was in Further Spain, and finally the young Octavian had his veterans (Cass. Dio. 46.29.6). ${ }^{240}$ As each vied for power, Plancus' own political and military might made him a major figure to consider; should the fragile Amnesty give way, his involvement in the ensuing conflict would be inevitable. ${ }^{241}$ Indeed, by May $43 \mathrm{BC}$ when tensions were coming to a head at Mutina, the only hope of defeating Antony was a coalition of the western forces, those belonging to Lepidus, Pollio, and Plancus (Fam.

\footnotetext{
${ }^{237}$ White (2010) 6-10 offers an in-depth analysis of Fam. 12.16 and Trebonius' attempts to bolster ties with Cicero.

${ }^{238}$ For a definition of 'affiliative politeness' see Hall (2009) 13-14.

${ }^{239}$ See Watkins (2019) 64-67 and Leach (2006) 260 for more on Plancus as proconsul.

${ }^{240}$ Hall (2009) 178-9.

${ }^{241}$ Watkins (2019) 64-5.
} 
12.6.2, 10.14.1-2). ${ }^{242}$ More importantly however, Plancus, along with Decimus, had been appointed consul-designate for $42 \mathrm{BC}$ by Caesar (Fam. 10.3.2). ${ }^{243}$ This guaranteed position of authority marked him as a statesman whose loyalty it was crucial to cultivate over the coming months. ${ }^{244}$ Cicero, as Eleanor Leach remarks, was already certain of Decimus' disposition; the Liberator had confirmed his republican sensibilities on the Ides of March. ${ }^{245}$ Plancus, on the other hand, was an ambiguity. As a loyal partisan in both the Gallic and Civil wars, he had long benefited from Caesarian patronage and owed much of his political success to the dictator. ${ }^{246} \mathrm{With}$ little reason to approve of the assassination, it was entirely feasible that Plancus would reject Cicero's cause in support of Antony. ${ }^{247}$ Indeed, as consul for 44 BC, Antony was perhaps his "best bet" to secure the consulship which Caesar had allocated him. ${ }^{248}$

On the other hand, Plancus had a promising history of moderation. Known for cultivating relationships on both sides of civil conflict, he previously had helped Cicero in 46 BC with the matter of his friend C. Ateius Capito's inheritance (Fam. 13.29.5-6). ${ }^{249}$ More notably, Plutarch relays that Plancus spoke in favour of the Amnesty on March 17 (Plut. Brut. 19.1). ${ }^{250}$ He certainly had good reason to. Should Caesar's acta be retained, both Plancus' governorship of Gallia Comata (and any military glory this post may generate) and his imminent consulship would be preserved. ${ }^{251}$ Of course, Plancus was not unique in his support of the amnesty. Many longstanding Caesarians, not least Antony, recognized that this compromise was a "practical necessity" and agreed to pardon the assassins while maintaining Caesar's decrees. ${ }^{252}$ Nonetheless,

\footnotetext{
242 Watkins (2019) 98; Mitchell (2019) 165.

${ }^{243}$ Watkins (2019) 40.

${ }^{244}$ Hall (2009) 178-179.

${ }^{245}$ Leach (2006) 260.

246 Then again, most statesman — Liberators and Caesarians alike- had profited in some way from Caesar's regime. As for Plancus, he took up a position as legate under Caesar in 54 BC. In 45 BC the dictator appointed him both praetor and to the college of urban prefects. Caesar likewise was responsible for his position as proconsul of Gallia Comata from $44 \mathrm{BC}-43 \mathrm{BC}$ and for designating him consul for the year 42 BC. See Watkins (2019) 40; White (2010) 150.

${ }^{247}$ Which, in the end, he did. Watkins (2019) 102-4.

${ }^{248}$ Watkins (2019) 67.

${ }^{249}$ Mitchell (2019) 172; Hall (2009) 178.

${ }^{250}$ As Mitchell points out, at the time of the assassination Plancus was an "eminent praetorian and consul designate for two years hence" so it is indeed likely that he took a leading role in the debate. See Mitchell (2019) 172; Watkins (2019) 66.

251 Watkins (2019) 66; Mitchell (2019) 172.

252 Mitchell (2019) 172; Welch (2012) 121-2.
} 
Plancus' very public support appealed to Cicero. His willingness to "reconcile the forces at Rome and seek a harmonious outcome" signalled both loyalty to the Republic and the possession of more moderate Caesarian values. ${ }^{253}$ Plancus, then, was malleable. Though his ambitions remained unclear, Cicero judged that he could be swayed to join the anti-Antonian coalition. It was not until mid-September, however, that the statesman began his campaign of epistolary eunoia. ${ }^{254}$ This is perhaps because tensions between Cicero and Antony had come to a head earlier in the month. Antony lashed out at Cicero in a Senate meeting on September 1 and the orator retaliated the following day by delivering his First Philippic (Cic. Phil. 1.11) ${ }^{255}$ While Plutarch relates that both men quietly ignored one another following the incident, it likely prompted Cicero to double down on his recruitment efforts in preparation for any conflict to come (Plut. Vit. Cic. 43.6). ${ }^{256}$ Plancus, with proconsular imperium, the dignitas of a consul-designate, and a network of Caesarian amicitia behind him, would undoubtedly make for a valuable addition to the statesman's senatorial cause.

\section{Unconditional Affection}

It is on the basis of old familial acquaintance that Cicero first and foremost establishes a sense of unconditional affection and commonality with Plancus. To the younger Caesarian he writes

My friendly connection with your family, my dear Plancus, came into being sometime before you were born. My affection towards yourself dates from your early childhood. When you became a grown man, my desire and your choice established a familiar friendship (Fam. 10.3.2).

It takes only a few lines for Cicero to weave a narrative of goodwill with which to appeal to his addressee. ${ }^{257} \mathrm{He}$ begins by expanding the frame of benevolence beyond Plancus, revealing a longestablished relationship with his family. The terms he employs to describe this connection-

\footnotetext{
${ }^{253}$ Leber (2015) 44.

${ }^{254}$ With the exception of Fam. 13.29 (sent ca. beginning of $46 \mathrm{BC}$ ), there is no surviving correspondence between Plancus and Cicero prior to September 44 BC.

${ }^{255}$ I return to the Philippics in Chapter Three.

${ }^{256}$ Watkins (2019) 72.

${ }^{257}$ On Fam. 10.3 see Hall (2009) 179-80.
} 
necessitudo and domus - are of some note. Necessitudo, according to Hellegouarc'h, is a quasifamilial relationship often used to express ties between brothers-in-law, a father and his son-inlaw, or stepfathers and stepsons. ${ }^{258}$ So too is it hereditary. The bond of necessitudo can be passed from generation to generation and, as such, is often considered stronger than amicitia. ${ }^{259}$ Cicero's use of the word, then, instantly suggests a high level of closeness between himself and Plancus' family. It also acts as an invitation for Plancus to accept Cicero's friendship as inheritance from his father (Fam. 13.29.1). ${ }^{260}$ To further stress this intimacy the statesman relates that his connection is specifically to Plancus' domus. Such a broad term can "incorporate the entire 'house' over multiple generations and include cognates" ${ }^{261}$ Here he is perhaps alluding to some "unspecified kinship ties" established well in the past between the Cicerones and the Planci. ${ }^{262}$ In any case, we know from other correspondence that Cicero was certainly close to Plancus' father. He has described their necessitudo as being "most valid and most delightful" and often highlights the mutual affection they shared (Fam. 13.29.1, 10.5.1; Att. 16.16a.1). Though Cicero discloses little else regarding the extent of their relationship, by mentioning this familial connection at the beginning of his letter he makes an appeal to constantia. ${ }^{263}$ That is, the past friendship between Cicero and Plancus' father ought to sustain a friendship between Cicero and Plancus in the present. At the very least, the knowledge that there existed a substantial history of goodwill between his father and Cicero ought to render Plancus receptive to the statesman's benevolent overtures.

Continuing the theme of long-standing familial acquaintance, Cicero stresses that, because of the close bond he shared with Plancus' father, he has had amor for Plancus ever since he was a young boy (Fam. 10.1.2, 10.3.2, 10.5.1). ${ }^{264}$ Once again, the language he employs is

\footnotetext{
${ }^{258}$ Hellegouarc'h (1963) 72.

${ }^{259}$ Hellegouarc'h (1963) 72-4; Watkins (2019) 27.

${ }^{260}$ Watkins (2019) 27.

${ }^{261}$ Watkins (2019) 27. For more on the definition of domus and the Roman conception of family see Saller (1984) 342-349.

262 Watkins (2019) 27. Watkins notes that it is possible the two equestrian families came into contact sometime in the second century BC, perhaps they "moved in the same social circles in southern Latium" or were united by "overlapping commercial interests".

263 On constantia see Tracy (2012); Hellegouarc'h (1963) 283-5.

${ }^{264}$ Hall (2009) 178.
} 
revealing. Amor typically describes the affection that exists between lovers, relatives, or very close friends. ${ }^{265}$ It can likewise exist in a political context. When applied to political relationships, amor designates an incredibly close bond of amicitia ${ }^{266}$ Here, Cicero uses the term in its fullest sense to convey the complex familiaritas he feels towards Plancus. Having known him since childhood, the statesman cares a great deal for his addressee. This is accentuated by Cicero's expression of pleasure at having watched Plancus mature (Fam. 10.3.2). Over the years, the young boy has transformed into a well-rounded man, one who most importantly has developed “intellectual tastes" similar to Cicero's own (Fam. 10.3.4) ${ }^{267}$ This mention of intellectual affinity is perhaps an allusion to Cicero's role as Plancus' boyhood teacher. Though nothing concrete is known of Plancus' childhood, Thomas Watkins proposes that he spent his formative adolescence, perhaps around the early $60 \mathrm{~s} \mathrm{BC}$, studying under Cicero. ${ }^{268}$ That Plancus, now an adult, is demonstrating an adherence to Cicero's prior guidance is surely gratifying for the statesman. More importantly, however, it provides Cicero with another channel to tap for amor. Not only does he feel affection for Plancus on the basis of familial association, but as a result of their past mentor-mentee bond.

Here, Cicero's purpose in underlining their long-term connection was to charge his eunoia with "paternalistic benevolence". ${ }^{269}$ There was no better way to convey the genuine and unaltering affection required of an amicus than to fashion himself as a parental figure. By consistently referencing his friendship with Plancus' father and his close acquaintance with the addressee since boyhood, Cicero demonstrates that the goodwill he feels for Plancus is equivalent to that which a father feels for his son. ${ }^{270}$ Such self-positioning on the statesman's part may appear overzealous but, as previously noted, eunoia is founded on reciprocity. One must first characterise

\footnotetext{
${ }^{265}$ Hellegouarc'h (1963) 146-7.

${ }^{266}$ Hellegouarc'h (1963) 146-7.

${ }^{267}$ Watkins (2019) 25.

268 Watkins (2019) 25. The evidence supporting this is limited. The only sources attesting the early relationship between Cicero and Plancus are the letters they exchanged in the 40s BC and there is no explicit mention of tutelage within them. See also White (2010) 150 n. 40.

${ }^{269}$ Leach (2006) 253.

270 Watkins (2019) 26, 73. See also Leach (2006) 253; Hall (2009) 178.
} 
themselves as benevolent towards the audience in order to elicit the same response in return. ${ }^{271}$ Thus, in exhibiting this fatherly affection, Cicero seeks to evoke in Plancus a similarly robust sense of amor and familiaritas. This rhetorical tactic, at least superficially, appears to have worked. Plancus' eloquent reply reads

I have many reasons to be punctilious - your relations with my father, the respect I have paid you since childhood, and your reciprocal affection for me. (...) Therefore, my dear Cicero, be assured that (as our respective ages allow) in cultivating your friendship I have invested you, and only you, with the sacred character of a father (Fam. 10.4.1-2).

The younger Caesarian does not hesitate to reciprocate Cicero's expression of familial benevolence. Employing language similar to Cicero's, he confirms that there exists an enduring bond of affection between them. ${ }^{272}$ Plancus even goes so far as to bestow the statesman with patriam sanctitatem, readily accepting the filial role in which he has been cast. ${ }^{273}$ At first glance, then, Cicero has successfully cultivated eunoia between himself and his addressee. By demonstrating goodwill towards Plancus, Cicero secures the sentiment in kind and renders his ethos trustworthy. However, the distinct disparity between what Plancus says and what Plancus does suggests his proclamations of benevolence are more calculated than they appear. ${ }^{274}$ That is, as Peter White aptly remarks, the Caesarian "had a way of wrapping himself in Ciceronian camouflage when writing letters". ${ }^{275}$ He expertly plays off of the statesman's affectionate words to initiate a fulsome father-son dynamic and, in doing so, performs the role he thinks will most appeal to Cicero. ${ }^{276}$ This is not to say Cicero's efforts had failed. Aristocratic social relations in

\footnotetext{
${ }^{271}$ Sattler (1947) 59.

${ }^{272}$ Hall notes that Plancus' comments "clearly take their cue" from Cicero's own previous remarks. See Hall (2009) 180 for the echoes between Fam. 10.4.1 and Fam. 10.3.2.

${ }^{273}$ Hall (2009) 180.

${ }^{274}$ As one example, shortly after Plancus promised Cicero that he would "ever be at the service of the commonwealth" (Fam. 10.4.3), rumours of his negotiating with Antony spread (Cic. Phil. 5.5, 7.3, 12.13, 13.37). Though not outright damning, this incident indicates that Plancus does not "feel strictly obliged to follow Cicero in obedient, filial fashion", Hall (2009) 181. More generally, Plancus' famous reputation as a time-server and his proclivity for "incessant self-explanation" likewise points to his unreliability, White (2010) 156.

${ }^{275}$ White (2010) 158.

${ }^{276}$ Hall (2009) 181; White (2010) 158.
} 
Rome were so deeply rooted in convention and superficial ritual that it mattered little whether or not their mutual goodwill was genuine. ${ }^{277}$ Either way, the conditions for eunoia had been met and Cicero used this to his rhetorical advantage.

Indeed, by cultivating eunoia within this father-son framework, Cicero strategically fashions himself as a figure of authority over his addressee. The statesman's paternalistic benevolence, as we will see, acts as a prelude to his equally paternalistic criticism of Plancus and permits him to admonish the Caesarian under the guise of fatherly affection. ${ }^{278}$ The first of his criticisms concerns Plancus' non-committal. Here, one excerpt is of particular note:

You are of course aware, for nothing could escape you, that there was a period when the world thought you too much at the service of the times. (...) Affection, rather than any notion that you were in need of admonition and advice made me think fit to write you in this strain (Fam. 10.3.3-4)

At the time of writing this letter-around December 944 BC-Cicero's concern about Antony was steadily growing. He had departed the city in late November to assume his position in Cisalpine Gaul and the statesman was anxious to forcefully resist this takeover despite its legality (Fam. 11.72-3). ${ }^{279}$ With the exception of Decimus, Plancus was the closest commander who possessed the imperium necessary to oppose Antony. ${ }^{280}$ Thus, in an effort to persuade Plancus to act, Cicero launched his complex programme of paternalistic criticism. His primary accusation is that the Caesarian had shown himself to be excessively enslaved to the times. This may mean one of two things. The most common interpretation maintains that Cicero is casting Plancus as a timeserver; someone who, out of self-interest, tends to be fickle or ambiguous in their actions and decision-making. ${ }^{281}$ By contrast, Hannah Mitchell proposes that Cicero's comment is more

\footnotetext{
${ }^{277}$ For the performative nature of aristocratic social relations see e.g. Flower (2011); Verboven (2011); Hall (2009).

${ }^{278}$ Leach (2006) 253; Hall (2009) 178-80.

${ }^{279}$ Mitchell (2019) 165. Control of Cisalpine Gaul was transferred to Antony in June 44 BC by way of an assembly vote. It was, however, under duress (Cic. Phil. 1,6; App. B Civ. 3.27).

${ }^{280}$ Mitchell (2019) 165.

${ }^{281}$ For example, Syme (1939), Nisbet \& Hubbard (1970), and Watkins (2019) each retain this interpretation in their various analyses of Plancus' character (though Watkins frames it as a positive attribute).
} 
specifically related to Plancus' behaviour under Caesar's rule. ${ }^{282}$ The orator had long been rhetorically fashioning Caesar's dictatorship as a form of unavoidable slavery and every statesman, he argued, had been enslaved by Caesar to some degree (Cic. Phil. 1.15). Nonetheless, there were those who believed that Plancus had "done more than was strictly necessary to survive". ${ }^{283}$ He had been enslaved nimis— too much—and benefitted greatly as a result. No matter the interpretation, Cicero's remark is intended to be condemnatory.

A month later, Cicero engages in a similar discourse. The topic of Plancus' non-committal is once again broached and the statesman criticises the Caesarian for his dependence on circumstance. Cicero writes

Hitherto (your admirable good nature and good sense allow me to put my thoughts freely into words) you appear to have won brilliant success with luck on your side. That would not, it is true, have been possible without merit. Nonetheless, the greater part of your achievements is credited to Fortune and circumstances. (...) I admonish you as a son, I hope for you as for myself, I urge you as one addressing a very dear friend in his country's cause (Fam. 10.5.3).

In Cicero's eyes, Plancus has not yet shown himself to possess the proactive drive necessary for greatness. He is a man too comfortable simply adapting to situations as they arise and, as a result, is cocooned in a false sense of dignitas. Like the previous letter, Cicero's comments here are decidedly admonitory. However, he does not criticize Plancus for criticism's sake. He instead uses censure to establish a foundation on which to make an appeal to the Caesarian. By expressing reservations about Plancus' past behaviour, Cicero creates the impression that he had somehow failed to fulfil his obligations as both son and amicus. ${ }^{284}$ Withholding praise gives Plancus something to aspire to and motivates him to remedy his questionable reputation by joining the senatorial cause. ${ }^{285}$ It was, after all, a friend's duty to facilitate the moral improvement of his

\footnotetext{
282 Mitchell (2019) 166-7.

${ }^{283}$ Mitchell (2019) 167.

${ }^{284}$ Meyer (2000) 162.

${ }^{285}$ Mitchell (2019) 167-9.
} 
friend (Cic. Amic. 89). At the same time, Cicero had to ensure he was not too severe in his admonition. Excessive criticism would only serve to alienate Plancus further and render persuasion all the more difficult. ${ }^{286}$ It is here where eunoia becomes essential. Cicero navigates the sharpness of his accusations by manipulating the paternal goodwill he has established. The criticism, Cicero claims, stems solely from a place of affection and he berates Plancus only as a father would his son. ${ }^{287}$ In this sense, the statesman is restating his earlier Nestor persona, modelling himself as more of a well-meaning mentor than a malicious critic. Hall acknowledges that the Caesarian could easily have taken offence to Cicero's "potentially patronizing" selfpositioning. ${ }^{288} \mathrm{He}$ was, after all, a distinguished commander and proconsul whose expertise had made a good impression on Caesar. ${ }^{289}$ Nevertheless, the eunoia cultivated by Cicero is intended to reduce this sense of asymmetry. Plancus will respect the statesman's advice out of gratitude for the fatherly benevolence he has been shown. ${ }^{290}$

What is more, Cicero lessens the impact of his censure by establishing a juxtaposition between Plancus' past actions and his present potential. Because of the long-standing familial eunoia they share, Cicero knows the Caesarian well enough to understand that his previous behaviour is not representative of his true self (Fam. 10.3.3). ${ }^{291}$ The statesman is willing, then, to dismiss Plancus' questionable past on the condition that, in the present crisis, his conduct remains consistent with his genuine nature and the amicitia between them. ${ }^{292}$ Indeed, out of fatherly affection, Cicero offers advice to the Caesarian on how best to embody this authentic self once more. He beseeches Plancus to

\footnotetext{
${ }^{286}$ Mitchell (2019) 167-8.

${ }^{287}$ White (2010) 153. As a point of contrast, Cicero's letter to Lepidus (Fam. 10.27) is essentially rude in its criticism of the addressee. Watkins suggests that this is because Cicero no longer believed he could successfully exert his influence over Lepidus. See Watkins (2019) 91-2; Hall (2009) 186.

288 Hall (2009) 180.

289 Nonetheless, as Hall also reminds us, Plancus had to "accept and negotiate" the conditions of deference attached to their differences in age and dignitas. Cicero is both older than Plancus and a consular, therefore he is inherently owed more esteem. Hall (2009) 180.

${ }^{290}$ Hourcade (2018) 103.

${ }^{291}$ White (2010) 153.

${ }^{292}$ Mitchell (2019) 167.
} 
dissociate yourself from those to whom no choice of yours but bonds forged by circumstances have attached you. (...) separate yourself from all connection with disloyal citizens, persons utterly unlike you (...) offer yourself to the Senate and all honest men as adviser, principal, and leader (Fam. 10.6.2-3).

The statesman's message here is clear. Plancus must renounce his superficial Caesarian connections and instead attach himself to someone with whom he has a complex and deep-seated bond, forged not by circumstance but by decades of close acquaintance. This someone must also be loyal to the commonwealth and represent something of an alter ego to Plancus. Having established familial eunoia with his addressee, Cicero ultimately fashions himself as the ideal candidate. He was close to Plancus' father, has felt amor for Plancus himself since childhood, and the two share similar intellectual tastes. It is only natural, then, that they should be alike in their politics. ${ }^{293}$ After all, true amici, despite the pressures of public life, are always in full agreement on matters of the state and will work together for its betterment (Cic. Amic. 22-26, 32-44, 1004). ${ }^{294}$ By imploring Plancus to accept the intense paternal eunoia he has cultivated, Cicero in turn encourages the Caesarian to recognize the ideological commonality between them and embrace the "spirit of Republican government". ${ }^{295}$

\section{$\underline{\text { Praise }}$}

Praise and approval are essential in the cultivation of eunoia for, as Aristotle observes, it is fundamentally human to be more receptive to those who commend us and recognize our good qualities (Arist. Rhet. 2. 1381b14-15). ${ }^{296}$ So too does the reciprocal recognition of merit play a crucial role in establishing amicitia (Cic. Amic. 20). ${ }^{297}$ Of course, in order to receive praise, one must first accomplish something that is praise-worthy. In the case of Cicero and Plancus, while the statesman had been perfectly obliging in previous correspondence, it was not until April 43

\footnotetext{
${ }^{293}$ Watkins (2019) 73.

${ }^{294}$ Watkins (2019) 73; Leach (2006) 260; Brunt (1988).

295 White (2010) 167.

${ }^{296}$ Hourcade (2018) 99.

${ }^{297}$ Meyer (2000) 165.
} 
$\mathrm{BC}$ that his approval of the Caesarian began in earnest. This is because Plancus-it seemed-had finally pledged himself to the defence of the res publica in an official dispatch to the Senate (Fam. 10.8). The letter explained that, far from being a passive observer, he had spent the previous months discreetly strengthening his position. Plancus needed to confirm the loyalty of his men, his province, and the neighbouring governors Lepidus and Pollio before he felt secure enough to publicly declare his patriotism (Fam $10.8 .3-4) .{ }^{298}$ Now that he had achieved this, the Caesarian was ready to render his services to the Senate (Fam. 10.8.7) ${ }^{299}$ Plancus sent a similar declaration to Cicero personally. He writes

I have discharged to the commonwealth all that I took upon myself at your instigation and to which I am pledged by my solemn word to you given - I have always wanted your approval no less than your affection, and if in you I have secured a defender when at fault, I have also wished you to be the herald of my good works... (Fam. 10.7.1)

With vigour Plancus reaffirms his commitment to the state and reveals that it was his desire to please Cicero which prompted him to act. While this may well be another instance of "Ciceronian camouflage", his declaration of loyalty certainly delighted the statesman. ${ }^{300}$ It marked a distinct shift in their relationship and henceforth Cicero was more determined than ever to nurture this republican spirit and ensure Plancus did not stray from the new path he had chosen to follow. ${ }^{301}$

Here, praise was the tool with which to keep the Caesarian in check. By actively applauding his patriotism, Cicero provides Plancus with both the validation he seeks and an incentive to maintain his senatorial course of action. Fam. 10.12 is of particular interest. As the statesman's reply to Plancus' dispatch, this letter encapsulates the programme of praise that

\footnotetext{
${ }^{298}$ In defending his inaction, Plancus also points to Decimus as an example. Decimus had publicly declared his anti-Antonian intentions before he was suitably prepared and suffered a siege at Mutina as a result (Fam. 10.8.4). See Mitchell (2019) 173; Watkins (2019) 93; White (2010) 154.

${ }^{299}$ Despite this declaration, Plancus never did reach Italy in time to render his services at Mutina. Indeed, he only managed to cross the Rhone on April $26^{\text {th }}$, five days after the battle was over (Fam. 10.9.3). White (2010) 154.

${ }^{300}$ White $(2010) 158$

${ }^{301}$ Hall (2009) 186-7.
} 
Cicero employs in a number of other missives. ${ }^{302}$ He begins by personally commending his addressee:

I must heartily rejoice that you have brought such large resources to our country's defence and aid $(\ldots)$ a great part of my happiness is in your prestige, which I know is already of the highest and so will remain. (...) It was all no novelty to me, who knew you and remembered the promises you made in your letters to me... (Fam. 10.12.1).

Expressing pleasure in an addressee's achievements is a common feature of Cicero's more formal correspondence. He often uses "intensifying expressions" and assertions of joy to amplify the warmth between himself and the individual to whom he writes, be it genuine or not. ${ }^{303}$ While the laudation here seems fairly typical, in celebrating Plancus' offer of support, Cicero makes sure to praise his dignitas above all. ${ }^{304}$ Of course, Cicero explains, the Caesarian's prestige had always been great, but with this pledge of allegiance he has secured his dignitas for the years to come. Prestige was especially crucial to Plancus' sense of identity as a consul-designate. ${ }^{305}$ The Caesarian was anxious to prove his worthiness of the position by cultivating dignitas and building a good reputation (Fam . 10.7.2). Cicero expertly recognizes this desire and uses it to appeal to his addressee. He praises Plancus' dignitas to assure him that, by positioning himself against Antony, he has achieved an exceptional public standing and is undeniably on course for the consulship, a theme to which we will return presently. What is more, Cicero works hard to applaud the Caesarian without implying his declaration of loyalty was an unexpected one. Because of the closeness of their tie and the intensity of the eunoia between them, the statesman never once doubted Plancus or his intentions. This clarification allows Cicero to reduce the likelihood of Plancus interpreting the compliment as a backhanded one.

\footnotetext{
${ }^{302}$ Fam. 10.5 in particular.

${ }^{303}$ Hall (2009) 42. Hall lists the most common intensifying expressions as: singularis, incredibilis, valde, vehementer, mehercule, mirifice, mirabiliter, and mirificus.

${ }^{304}$ Hall (2009) 187. The familiar elements of Cicero's praise include his expression satisfaction at Plancus' achievements and use of the superlatives maxime and amplissimam. See also Hall (2009) 41-2.

${ }^{305}$ White (2010) 154.
} 
Cicero then shifts the frame of praise from his personal appreciation to that of the Senate's. "I assure you", he writes, "that no dispatch ever read in the Senate was more favourably received than yours" (Fam. 10.12.1). Indeed, Plancus' commitment to the res publica was so impressive that their expectations had been thoroughly surpassed (Fam. 10.12.1). As if to validate this claim, Cicero launches into an epistolary narratio. ${ }^{306}$ He weaves a detailed narrative to describe for Plancus the events of April 7, the day on which his official dispatch was read in the Senate. That morning Cicero was escorted from his home by a mass of "loyal patriots", all of whom rejoiced when he relayed to the them the news of Plancus' declaration (Fam. 10.12.2). He presented the letter to Cornutus, the City Praetor, and the Senate was immediately convened. Cicero here is sure to point out that the Senators were so eager to hear his dispatch that they thronged the senate house in great numbers (Fam. 10.12.3). The following day Cicero proposed that Plancus should receive honours for his dedication to the commonwealth. It was a motion which gained "widespread assent" before its unfortunate veto by Publius Titius (Fam . 10.12.3-4). Despite this, the statesman ultimately assures his addressee that

the Senate could not have been more responsible, resolute, and disposed to hear your praises than it was on that occasion; and the community at large is no less well disposed towards you than the Senate. Marvellous indeed is the unanimity with which the entire Roman people, and every type and order therein, has rallied to the cause of freedom (Fam. 10.12.4).

Thus Cicero concludes his description of events. A narratio such as this forms a crucial component of any attempt at persuasion. By constructing an uncomplicated yet especially detailed narrative, the rhetor ensures maximum plausibility and the appearance of unvarnished truth (Cic. Inv. rhet. 1.28-29). Cicero here recounts sequentially and in exhaustive detail the process by which the Senators and the people of Rome have come to celebrate Plancus. Stylistically mimicking a narratio allows him to convey to his addressee just how genuine and palpable the

\footnotetext{
${ }^{306}$ Meyer (2000) 118-119 discusses Cicero's use of epistolary narratio in the context of his post-exile correspondence.
} 
support for him is as a result of his newly announced commitment to the state. The eunoia initially cultivated by Cicero between himself and Plancus now flourishes in the wider community and this outpouring of collective praise is irrefutable proof that the Caesarian has chosen the right path.

Indeed, by weaving this narrative of universal praise, adoration, and goodwill, Cicero allows Plancus to sample the consular veneration he so desperately desires. As noted above, the Caesarian's utmost ambition was to prove himself worthy of the consulship and achieve widespread recognition (Fam. 10.7.2). Tapping into this desire, Cicero makes a final appeal for the addressee to

continue in your present course, and hand down your name to eternity. Despise all these prizes that have only the semblance of glory (...) True dignity lies in virtue; virtue is most conspicuously displayed in eminent services to the commonwealth. Such you have a splendid opportunity to render. You have grasped it; do not let it slip (Fam. 10.12.5).

Cicero's message is simple. The only means by which Plancus can realise his goal of eternal celebrity is to possess genuine dignitas. He must gain prestige through "appropriate recognitions and reception" of public deeds, namely acts of loyalty to the state (Cic. Off. 2.36). ${ }^{307}$ Any other form of recognition is superficial and therefore cannot aid Plancus in his ambitions. This is certainly not the first time that the statesman has utilized future glory as a "spur to action" ${ }^{308}$ In March he explained to Plancus that

a number of persons have been called consuls, none of whom have been considered a consular unless he displayed patriotism worthy of the office (...) If such are your acts and sentiments, you will not only be a consul and consular, but a great consul and consular (Fam. 10.6.3). ${ }^{309}$

\footnotetext{
${ }^{307}$ Leach (2006) 261. For dignitas see Hellegouarc'h (1963) 388-411.

${ }^{308}$ White (2010) 145; Leach (2006) 261.

${ }^{309}$ The overall tone of this letter is decidedly less laudatory than Fam. 10.12. Fam. 10.6 is Cicero's response to Plancus' suggestion of peace with Antony and is therefore more chastising. See also Fam. 10.10 and Fam. 10.14 for Cicero's use of future glory as a spur to action.
} 
Cicero blatantly uses the consulship to incentivise Plancus into compliance. If his addressee wants to be a memorable consul he must do his patriotic duty by renouncing his former Caesarian ties, declaring himself in opposition to Antony, and offering his services to the defence of the res publica. Fortunately for Plancus, his recent commitment to Cicero's senatorial cause has secured both his future dignitas and his gloria (Fam. 10.7, 10.8). By remaining consistent in his moral character and fulfilling the pledge he made to the Senate, the Caesarian is guaranteed to enjoy a successful consulship. ${ }^{310}$ However, Cicero warns, the praise and veneration in which Plancus has thus far relished is conditional. It could easily slip from his grasp should he wander from the republican path.

\section{The Will to Help}

"Goodwill", Cicero explains, "is won principally through kind services; next to that, it is elicited by the will to do a kind service, even though nothing happens to come of it" (Cic. Off. 2.32). The demonstration of a willingness to lend help is certainly an important final stage in the cultivation of eunoia for it symbolizes the meaningful progression from natural affection and benevolence to a genuine amicitia. ${ }^{311}$ As we have seen, though benevolentia is of course fundamental in genuine amicitia, a friendship in which this goodwill has not been "made manifest by an exchange of officia" can hardly be considered a friendship at all. ${ }^{312}$ It is neither a relationship of sheer affection nor of sheer utility, rather, it strikes a unique balance between the two and binds friends together in a web of obligation, benevolence, and honour (Cic. Inv. rhet. 2.167-8; Off. 1.56-7) ${ }^{313}$ By consistently and conspicuously demonstrating the will to help his addressee, Cicero conveys to Plancus his genuine desire to fulfil the obligations of amicitia and form a sincere bond with his addressee. This in turn, according to the conventions of amicitia, should prompt Plancus to return the sentiment in kind and motivate him to aid Cicero in his defence of the res publica. The

\footnotetext{
${ }^{310}$ White (2010) 145-6 discusses Cicero's tendency to ground his appeals to both Plancus and Decimus in arguments about "moral consistency".

${ }^{311}$ Romilly (1958) 92; Sattler (1947) 59; Verboven (2011) 411.

${ }^{312}$ Verboven (2011) 411.

${ }^{313}$ Brunt (1988) 355.; Verboven (2011) 412.
} 
statesman in effect co-opts the language of eunoia and amicitia to "create an appearance of friendship in the service of expediency". 314

Importantly, Cicero exhibits his will to support the younger Caesarian by casting himself as the protector and promoter of Plancus' dignitas. ${ }^{315}$ He pledges to help him realise his future ambitions by advancing his prestige. Initially, however, these promises of support were decidedly ambiguous. Cicero simply relays to Plancus that he has "a strong sympathetic interest in your future dignity" and he is "entirely devoted to your advancement" (Fam. 10.1.3, 10.2.2, 10.3.4). He does not specify how he will go about supporting his addressee's dignitas, only that he has aspirations to do so. ${ }^{316}$ Though vague, these offers of assistance nonetheless partially fulfil the requirements of eunoia. As noted above, when cultivating benevolence, demonstrating the will to render a service is almost as effective as the service actually rendered (Cic. Off. 2.32). ${ }^{317}$ It acts as a binding commitment, the non-delivery of which may well threaten the stability of the relationship. ${ }^{318}$ Plancus, then, is assured that the statesman wants what is best for him and will honour his promise. In fact, Cicero did attempt to make a minor "down payment" on his offer of support by mentioning Plancus in the Philippics; once merely listing him as incoming consul and later offering him a brief compliment (Cic. Phil. 3.38, 13.16, 44). ${ }^{319}$ This was a decidedly feeble attempt to promote the Caesarian's dignitas. Even more questionable was Cicero's failure to support a decree in Plancus' honour in September 44 BC. ${ }^{320}$ The blunder was such that he composed an apologia to the Caesarian, ultimately citing fear for his own safety as justification for his absence in the Senate (Fam. 10.2.1-2). ${ }^{321}$ Three times, then, had Cicero fallen short of his

\footnotetext{
${ }^{314}$ Leach (2006) 261.

315 Watkins (2019) 78; Leach (2006) 261.

316 White (2010) 155. This ambiguous offer to advance his addressee's dignitas is far from exclusive to Plancus. For similar promises to Decimus see Fam. 11.6, 11.5, 11.6a, 11.8, 11.14; for Cassius see Fam. 12.1, 12.2, 12.7; for Brutus see Ad Brut. 2.5, for Cornificius see Fam. 12.22, 12.22a, 12.24, 12.25, 12.30. ${ }^{317}$ Brunt (1988) 356.

318 Verboven (2011) 414.

${ }^{319}$ White (2010) 145-6, 155; Watkins (2019) 79.

${ }^{320}$ Plancus was likely to be honoured by a supplicatio for his victory over the Rhaeti, a success which later earned him a Triumph. See Shackleton-Bailey (1977) 480.

321 Watkins (2019) 74. Antony had stationed armed soldiers around Rome and Cicero feared voicing "independent political views" in the Senate House lest he come to harm (Fam. 10.2.1-2). See also Cicero's letter to Cassius (Fam. 12.2).
} 
promise to advance Plancus' career. He remained hesitant to throw his full weight behind a man who had yet to publicly commit to the senatorial cause. ${ }^{322}$

Of course, the statesman reconsidered his position after Plancus had declared himself at the service of the state in April 43 BC. Cicero's promises of support were no longer coated in ambiguity. Rather, he specified that he would "redeem his pledge" to promote Plancus' dignitas by awarding him honours in the Senate (Fam. 10.12.3-5, 10.13.1, 10.22.3) ${ }^{323}$ While Cicero could, and did, dispense praise with ease, honour conferred by the Senate on behalf of the commonwealth was a commodity far more desirable amongst statesmen. ${ }^{324}$ To be officially recognized in this way promised an increase in prestige and guaranteed public esteem for years to come. Cicero, as a skilled orator and distinguished consular, had the capacity to mediate the process by which awards were given. Procuring honours, therefore, became the statesman's principal resource with which to support and guide the actions of others. ${ }^{325}$ Indeed, the months after Caesar's assassination were "regularly punctuated" by decrees of public thanksgivings, commemorative statues, and state funerals. ${ }^{326}$ Following the victory at Mutina, for example, Cicero proposed an unprecedented fifty-day period of thanksgiving and that Decimus be named imperator (Cic. Phil. 14.11, 37; App. B Civ. 3.302) ${ }^{327}$ In Plancus' case, Cicero had made it clear in March that the Senate "would have declared its appreciation of your efforts and preparations and conferred high honours upon yourself" (Fam. 10.10.1). ${ }^{328}$ Unfortunately, the time was "not yet ripe" to support him in this way (Fam. 10.10.1). Plancus had yet to render concrete aid to the commonwealth and Cicero was firmly of the opinion that honours should only be given to those whose "great services had made them illustrious" (Fam. 10.10.1). In this exchange, Cicero is sure to cast himself as

\footnotetext{
${ }^{322}$ Leach (2006) 261.

${ }^{323}$ White (2010) 155.

${ }^{324}$ White (2010) 146. We see in Fam. 12.24.1 that Cicero marks a distinct contrast between laudare and ornare.

${ }^{325}$ White (2010) 146; Stockton (1971) 328.

${ }^{326}$ White (2010) 146.

${ }^{327}$ This motion notably prompted Brutus and a number of other statesmen to criticize Cicero for his lack of restraint in the bestowing of accolades (Ad Brut. 1.4a2, Fam. 11.10.1).

${ }^{328}$ Italics my own.
} 
genuine amicus willing to help his friend. Plancus must simply fulfil the obligations inherent in such a relationship first. ${ }^{329}$ And so he did.

Immediately following Plancus' April dispatch, Cicero set out in earnest to deliver on his promise of support. Fam. 10.12 represents his enthusiastic first attempt. ${ }^{330}$ As discussed above, the letter stylistically mimics a narratio so that Plancus may clearly comprehend the full extent of Cicero's advocacy. The statesman was adamant that his younger protégé should receive his due and readily motioned for honours to be bestowed (Fam. 10.12.3-4). Even when Publius Titius exercised his veto Cicero did not hesitate to "tame and vigorously put down" the tribune; such was his commitment to securing dignitas for Plancus (Fam. 10.12.4-5). He demonstrated a similar enthusiasm one month later, writing

As soon as the opportunity to enhance your standing came my way, I left nothing undone to your honour-no recompense of merit, no verbal accolade. That you will be able to see from the terms of the Senate's decree; they are exactly those of my motion (...) I felt it incumbent upon us to consider what was due you from the commonwealth, even though you asked for nothing (Fam. 10.13.1).

An essential component in Cicero's self-fashioning as an amicus was to actually fulfil his end of the social contract. ${ }^{331}$ Thus, though the precise nature of the decree is unclear, the statesman is sure to capture the intensity with which he championed, and won, Plancus' cause in the Senate. Doing so reveals to the addressee that their friendship, now made tangible by the exchange of officia, is a genuine one (Cic. Off. 1.56). ${ }^{332}$ At the same time, Cicero makes every effort to appear as though his act of service was borne from a selfless desire to help his friend. To do otherwise would only serve to highlight the more emotionally shallow motives underpinning his passionate advocacy. ${ }^{333}$ This altruistic rhetoric reaches its peak when the statesman declares that Plancus'

\footnotetext{
${ }^{329}$ Watkins (2019) 78; Meyer (2000) 150.

${ }^{330}$ White (2010) 155.

${ }^{331}$ Meyer (2000) 162.

${ }^{332}$ Verboven (2011) 411; Meyer (2000) 165.

${ }^{333}$ Hourcade (2018) 88; Verboven (2011) 411.
} 
future is a higher priority than his own (Fam. 10.1.1, 10.10.2, 10.12.5). As a true amicus ought, Cicero signals that he is willing to do more for the Caesarian than he would do for himself in order to protect and promote his dignitas (Cic. Amic. 57). ${ }^{334}$

\section{$\underline{\text { Summary }}$}

Because connections counted for far more than ideology during civil strife, it was upon eunoia that Cicero had to rely in order to diversify his network of amicitia, forge alliances, and unite the Senate against Antony. While he of course engaged in this exchange of goodwill with a number of the Republic's key players, it is Cicero's correspondence with Plancus which is particularly useful for unpacking his use of epistolary benevolence. In it, we observe how Cicero fashions himself as an amicus by drawing on the three fundamental aspects of eunoia: unaltering affection, praise, and readiness to render services. Having been acquainted with Plancus since childhood, the statesman first and foremost cultivated a paternal eunoia between himself and his addressee. Not only did this allow him to convey unconditional affection, it gave Cicero license to criticise Plancus for his past failures. Withholding praise in this way incentivised the Caesarian to remedy his reputation as a timer-server by joining the republican cause. True amici should, after all, be alike in their politics. At the same time, as a friend, it was essential that Cicero offer praise where praise was due. He applauded Plancus' declaration of patriotism to motivate him to remain on the senatorial path. He likewise reminded the Caesarian that the only way he could secure the eternal praise and public esteem he so desperately desired was through service to the state. Finally, and perhaps most importantly, Cicero pledged to support Plancus by protecting and promoting his dignitas. Though his promise was initially an ambiguous one, after Plancus' public commitment to the res publica, Cicero procured for him senatorial honours. With this act of service he in effect fulfilled his duty as an amicus and signalled the formation of a genuine bond of amicitia. Addressee, then, is bound to addresser in a web of mutual obligation.

\footnotetext{
${ }^{334}$ Brunt (1988) 352. This is not something unique to Cicero's correspondence with Plancus. He makes similar declarations in letters to Decimus (Fam. 11.6, 11.5, 11.6a, 11.14), Cassius (Fam. 12.1, 12.2, 12.7), Brutus (ad Brut. 2.5), and Cornificius (Fam. 12.22, 12.22a., 12.24, 12.25).
} 


\section{Chapter Three}

\section{Aretē: Cicero as Saviour}

... when this same loathsome traitor asked me to what state I belonged, I answered, amid the plaudits of yourselves and of the Roman knights, 'to a state which could not exist without me' (Cic. Har. Resp. 17). ${ }^{335}$

As we have observed, Cicero worked diligently in the letters to fashion himself as both advisor and amicus in his campaign for post-Ides authority. However, the men with the most influence in Rome were those aristocrats who had won recognition and glory by carrying out good deeds in service of the state. In order to secure a more tangible position of power, then, Cicero needed to accomplish something truly exceptional for the sake of the commonwealth. There could be nothing more worthy of universal renown than to defend the res publica against a direct threat to its libertas. Thus, Cicero fashions himself as Rome's noble saviour; a man whose unparalleled patriotism, eloquence, and fortitude stands as a foil to Antony's vice. The cultivation of such an ethos demanded a sustained performance of civic dexterity and self-promotional rhetoric. Here, it is arete, more appropriately recast as its Latin equivalent virtus, which offers us a lens through which to examine Cicero's epistolary self-fashioning as the defender of the state. To Aristotle, arete $\bar{e}$ is "a faculty of providing and preserving good things" $(R h .1 .1366 \mathrm{~b} 3-4)$. It represents a set of attributes - wisdom, justice, courage - which allow an elite man to perform his role in society for the benefit of others. Similar is the Latin virtus. Typically translated as manliness, valour, or excellence, virtus is the ideal of Rome's political aristocracy. It denotes the winning of personal renown and gloria by carrying out good deeds in service of the state. To save the res publica itself, Cicero recognized, was an unparalleled performance of virtus. Thus, in an effort to protect the state from what he perceived as a genuine threat, and at the same time win personal glory for his own sake, he very publicly positioned himself as the defender of libertas.

335 Translation by (1923). 
However, because virtus relies on external recognition for its instantiation, Cicero faced the challenge of conveying his performance of civic fortitude in an epistolary medium. The statesman's distant correspondents were not in Rome and therefore could not view him in action. In his letters, then, Cicero had to recreate the reality of his virtue (as he understood it). First, having been absent since his exodus in April $44 \mathrm{BC}$, he needed to carefully fashion his return to the city. The statesman employs a Homeric grammar to cast his decision to turn back from Greece as a pseudo-mythical event, as though the res publica itself had called him home in its time of need. Doing so both mitigates any charge of inconstantia that his volte-face may have earned him and imbues his imminent struggle with a sense of cosmic significance. Once in Rome, he boldly launched his attack on Antony by way of the Philippics. The acme of his oratorical talent and political dexterity, these fourteen orations traced Cicero's sustained onslaught against the state's biggest threat. So too were they integral to his self-fashioning as saviour of Rome. As such, the statesman reproduces the key themes, rhetorical devices, and invective tropes from the Philippics in his correspondence; this way the addressees are able to experience the impact of his virtus despite their absence. These epistolary Philippics see Antony cast as a tyrant who threatens the very libertas of the res publica. Cicero, by recounting his delivery of the Third Philippic, revives his consular personae as dux togatus and parens patriae to stand as Antony's antithesis. He even goes so far as to don the sagum and exercise a kind of virtus reserved only for the martial arena. The result of his fierce patriotism is an epistolary ethos which, at least for the time being, grants Cicero a fresh position of authority as the helmsman of the post-Ides Senate.

\section{From Aretē to Virtus}

Arete and virtus are two of the most significant value concepts of classical antiquity. In order to best examine how Cicero employs these ideals in his post-Ides correspondence, it is first necessary to analyse them in their respective historical contexts and trace the development of arete from its Homeric origins to its recasting as virtus by the Romans. In Homer, aretē was what animated the Greek heroes. It denoted nobleness, physical courage, dexterity, and the drive to be best in 
battle. ${ }^{336}$ This strong emphasis on martial prowess rested upon the understanding that arete "operated within an economy of actions". ${ }^{337}$ That is, it depended on public reception and recognition of particular virtuous acts for its instantiation. ${ }^{338}$ Most notably, aretē finds its epitome in Achilles. The greatest of all Greek warriors, he was favoured by the gods for his prowess and feared by mortals for his ferociousness (Hom. Il. 1.72, 1.146). Because Homeric epic was central in Greek ethical thinking, during the late fifth and early fourth centuries $\mathrm{BC}$, the concept of arete remained the most noble quality a man could attain. ${ }^{339}$ Only here, it had broadened significantly to include the spheres of philosophy and rhetoric. Encompassing both intellectual excellence (wisdom, intelligence, prudence) and moral excellence (courage, justice, temperance), aretē was defined by Aristotle as the disposition which made a man 'good' and ultimately enabled him to perform his function well (Arist. Eth. Nic. 2.6.1106a2-4). ${ }^{340}$ It is not something that comes to an individual purely by nature. Rather, aretē is acquired by exercising the qualities that characterise it. Just as a man becomes a builder by building houses, he also becomes "just by doing just acts, temperate by doing temperate acts, and brave by doing brave acts" (Arist. Eth. Nic. 2.2.1103b415). ${ }^{341}$ The greatest of these virtues are those which have an external benefit. This is why, Aristotle claims, justice and courage are the most esteemed manifestations of arete (Arist. Rh. 1.1366b510). Courage drives men to carry out noble acts in times of danger and protect their community; similarly, someone who is just will act for the sake of common welfare and advocate for their dependents in times of peace (Arist. Rh. 1.366b6-8) ${ }^{342}$ Plato expressed this ideal best in his Meno when the titular character explains that

\footnotetext{
${ }^{336}$ Horner (1975) 1-10; Adkins (1984) 30; Hawhee (2002) 187.

${ }^{337}$ Hawhee (2002) 187.

${ }^{338}$ Hawhee (2002) 187; Horner (1975) 1-2; Jaeger (1939) 8; Adkins (1984) 35; Finkelberg (1998) 18.

${ }^{339}$ On the centrality of Homeric epic to Greek ethics see e.g. Smith (2001).

${ }^{340}$ Horner (1975) 94-5. Ball (1995) 74 proposes that a better translation of arete is 'role-related specific excellence'.

${ }^{341}$ Translation by Rackham (1926). Horner (1975) 95-6; Allard-Nelson (2001) 252; Rorty (2011) 722-3.

${ }^{342}$ Finkelberg (2002) 48.
} 
a man's arete is this - that he be competent to manage the affairs of his city, and to manage them so as to benefit his friends, and harm his enemies, and to take care to avoid suffering harm himself (Pl. Men. $71 \mathrm{E}){ }^{343}$

To 'manage the city's affairs' and perform civic duties was an essential requirement of an elite citizen of the polis. ${ }^{344}$ Only those who served the community in the appropriate arenas of politics and warfare could claim aretēe. It is for this reason that Isocrates' conception of aretē is firmly rooted in rhetoric. ${ }^{345} \mathrm{~A}$ man skilled in the art of persuasion was one who knew how to make wellreasoned decisions, exercise good judgement, and most importantly, he was an excellent orator (Isoc. Antid. 86-88, 270-5, 293-6). ${ }^{346}$ These noble attributes combined enabled him to perform his role well and guide the affairs of the city-state.

Though Rome had been in contact with Hellenistic society almost since the city's foundation, it was not until the first half of the second century $\mathrm{BC}$ that the two civilisations engaged in a profound political, social, and cultural exchange. While this period saw an influx of Greek manners and ideals into Rome, only those importations which passed the test of mos maiorum and could conform to already established principles were accepted. ${ }^{347}$ It seems plausible, then, that when the Romans encountered Greek aretē, they found that it encapsulated their own Latin virtus in the broader sense. ${ }^{348}$ Because both concepts were complex, indefinable, and multifaceted, they could signify each other without issue. Indeed, it was precisely this versatility which gave aretē and virtus political, social, and moral power. ${ }^{349}$ In the first instance — as with aretē - only a certain societal group was capable of striving for and acquiring virtus; that being the political elite. While theoretically the government of Rome was the Senatus Populusque Romanus, Syme

\footnotetext{
${ }^{343}$ Translation by Lamb (1924).

${ }^{344}$ On arete and its role in the Greek city-state see Finkelberg (2002).

${ }^{345}$ Horner (1975) 106.

${ }^{346}$ Horner (1975) 108-10.

${ }^{347}$ Earl (1967) 36-42.

${ }^{348}$ Balmaceda (2017) 25. For a detailed examination of the potential Greek origins of virtus and the process by which Romans absorbed — or rejected — other Hellenistic ideals see Earl (1967) 35-43. A wide range of other terms have been proposed as the Latin equivalent of arete including: praestantia, principatus, fortitudo, primae, successus, salus, res secundae, and morum probitas. See Finkelberg (1998) 19.

349 Balmaceda (2017) 25.
} 
aptly notes that "in all ages, whatever form and name of government (...) an oligarchy lurks behind the façade". ${ }^{350}$ In reality, the Senate consisted of several hundred men, each from the landed aristocracy, who had been elected to one of the principal magistracies. ${ }^{351}$ Within this exclusive group existed a select inner circle, the nobiles. These were the men whose previous ancestors had ennobled the family line by holding political office, more specifically the consulship, the consular tribunate, or the dictatorship. ${ }^{352}$ In the late republic it was typically, though certainly not always, from this nobility that candidates for the consulship were sought. ${ }^{353}$ As such, a noble's life was "moulded and directed" towards the cursus honorum with an eye to attaining its highest office. ${ }^{354}$ While this did engender a certain protectiveness, the aristocracy was far from unyielding in its exclusion of others. Rather, its attitude was one of what Donald Earl described as "carefully controlled inclusion". ${ }^{355}$ Novi homines - men who were first in the family to enter the Senate - could achieve great political success so long as they accepted and adhered to elite standards and expectations. ${ }^{356}$ Ultimately, then, the Roman aristocracy's chief concern was with politics. The elite were almost exclusively responsible for commanding armies, governing provinces, and shaping Rome's future by guiding policy within the Senate. ${ }^{357}$

Here, virtus was the concept in which this political aristocracy, nobilis and novus alike, "expressed its ideal" ${ }^{358}$ While the term is not directly translatable, Earl suggests that 'manliness' is perhaps as close as we can get. ${ }^{359}$ At its core, virtus describes the essence and quality of the man (vir). ${ }^{360}$ It is a largely subjective concept for, as our notion of man's purpose changes, so will

\footnotetext{
350 Syme (1939) 7.

${ }^{351}$ Horner (1975) 118.

352 Tatum (2018) 181; Earl (1967) 12-13; Hellegouarc'h (1963) 477; Horner (1975) 118.

${ }^{353}$ Tatum (2010) 181; Horner (1975) 119.

${ }^{354}$ Horner (1975) 119. For a more general overview of the Roman aristocrats' political prerogative see Syme (1939) 10-27.

${ }^{355}$ Earl (1967) 13.

${ }^{356}$ Notable novi homines include Cato the Elder (cos. 195, cens. 184), Gaius Marius (cos. 107, 104-100, 86), and of course Cicero (cos. 63). For novi homines in general see Earl (1967) 44-58.

${ }^{357}$ Earl (1967) 14.

${ }^{358}$ Earl (1967) 20.

${ }^{359}$ Earl (1967) 20. On the etymology of virtus see Hellegouarc'h (1963) 244.

360 vir is also the Latin word for hero, as we see in Vergil's famous opening line: arma virumque cano (Verg. Aen.1.1). On vir and virtus see also Cic. Tusc. 2.43.
} 
our definition of his proper conduct and nature. ${ }^{361}$ Because the Roman aristocrat was chiefly a political being, he "defined his ideal way of life as above all political". ${ }^{362}$ Virtus for him, therefore, consisted in the winning of glory by carrying out good deeds in service of the res publica. This ideal is well-illustrated in the oft-cited Scipionic Epitaphs, a series of laudatory funerary inscriptions which preserved for posterity the activity of the noble Scipio family. Take, for example, the tomb of L. Cornelius Scipio (cos. 259 BC). His epitaph reads

This man Lucius Scipio, as most agree, was the very best of all good men at Rome. A son of Barbatus, he was aedile, consul, and censor among you; he it was who captured Corsica, Aleria too, a city. To the Goddesses of Weather he gave deservedly a temple $\left(C I L 1^{2} \cdot 9\right){ }^{363}$

The inscription begins with an assertion of elite pre-eminence; Scipio is the most outstanding of all elite men. To support this bold statement of supremacy, it details the civil offices he held, his military victories at Corsica and Aleria, and his service to the gods by way of gift-giving. These three spheres — government, army, and state religion —-were the essence of Roman public life and, as such, were the only appropriate arenas for the aristocratic performance of excellence. ${ }^{364} \mathrm{~A}$ man could cultivate virtues such as wisdom, courage, and justice privately. However, because this was a society oriented to action, it was only by physically exercising these virtues in the public sphere that he could fully convey his virtus (Cic. Off. 1.19). ${ }^{365}$ An aristocrat had a responsibility towards Rome, of supporting it, preserving it, and expanding it. ${ }^{366}$ The elite ideal, therefore, was to achieve great deeds by serving the state in the role of general, orator, and senator. Scipio certainly fulfilled these aristocratic requirements. In his various magisterial offices, he demonstrated sound

\footnotetext{
${ }^{361}$ Hellegouarc'h (1963) 244; Earl (1967) 20-21.

362 Earl (1967) 21.

363 Translation by Warmington (1940).

${ }^{364}$ Earl (1961) 18-19; Hellegouarc'h (1963) 244.

365 The Romans were hostile to the purely private cultivation of virtue. Terms such as ignavia (idleness, laziness) and inertia (inactivity, indolence) had a distinctly pointed implication: avoidance of the political arena. Similarly, Cicero had no patience for those aristocrats who stepped away entirely from the public sphere. He called them piscinarii (fish fanciers) for, in retirement, they spent their days curating extravagant fishponds (Cic. Att. 1.20.3, 1.19.6). See Earl (1967) 23; Balmaceda (2017) 40-1.

366 Balmaceda (2017) 41.
} 
judgement and outstanding leadership to guide the res publica towards success. As a warrior he exercised his bravery and risked his life for the greater good, securing two victories over Rome's enemies. Finally, in a display of devotion, generosity, and wealth, Scipio erected a temple to the Tempestates for betterment of the city's collective piety.

There is, however, a dualism within virtus. An aristocrat did not serve the state solely for its own sake nor was his virtus considered a reward in itself. Rather, he participated in public life and achieved great deeds in order to win personal renown and gloria. ${ }^{367}$ The highest elite aspiration, Cicero writes that gloria

consists in the credit for honourable deeds and the reputation for great services benefitting the Republic, approved by the testimony of the best among us and also by the multitude (Cic. Phil. 1.29). ${ }^{368}$

Here, because virtus had to be exercised in the public sphere, its prize, gloria, was likewise dependent on external consensus and the universal recognition of an individual's exemplary performance (Cic. Off. 2.31). ${ }^{369}$ One was not glorious until his community deemed him to be so. As such, military exploits were a primary source of gloria for most of Rome's great men. Scipio Africanus, Scipio Aemilianus, L. Aemilius Paullus Macedonicus, Gaius Marius, and Pompey the Great are each singled out by Cicero as having achieved "signal fame" and "undying glory" by way of their outstanding martial prowess (Cic. Cat. 4.21). ${ }^{370}$ Though of course their actions benefitted the whole of Rome, these men used their military talents to advance their own cause among the aristocracy and win eternal personal renown. Indeed, this pursuit of gloria was the fundamental justification for the nobility's martial activity and, in their eyes, it was what distinguished them from the masses. ${ }^{371}$

\footnotetext{
367 Earl (1967) 34; Balmaceda (2017) 38.

${ }^{368}$ Translation by Shackleton Bailey (2010).

${ }^{369}$ Cicero offers a detailed discussion of gloria and its elements in De Officiis 2.31-51. See also Tatum (2018) 168, 239; Earl (1967) 30; Hellegouarc'h (1963) 369-70.

${ }^{370}$ See Macdonald (1976) 161 n. a-d. See also Hellegouarc'h (1963) 372.

${ }^{371}$ Hellegouarc'h (1963) 369-70.
} 
However, as noted above, the political sphere was just as vital to the aristocratic performance of virtue. Gloria, therefore, was also won through public office (Cic. Rep. 1.38, Brut. 281, Off. 1.76; Liv. 3.24.11; Vell. Pat. 2.12.6). The praetorship, consulship, and proconsulship in particular offered the political elite the opportunity to demonstrate their civic fortitude before an audience of their peers. ${ }^{372}$ Where military victory only benefitted the state in the short term, exceptional statesmanship improved Rome on a systemic level. For this reason, Cicero argued that the glory won from public office far outweighed that gained on the battlefield (Cic. Off. 1.756). ${ }^{373}$ Essential to this elite pursuit of political gloria was skill in oratory (Cic. De or. 1.58, 3.111, Brut. 23, 32, 92; Sall. Cat. 3.1). ${ }^{374}$ The ability to persuasively address an audience-be it before the Senate, in a contio, as an advocate, or while canvassing for office-was instrumental in securing public support and acquiring fame (Cic. Off. 2.48). ${ }^{375}$ It allowed an aristocrat to demonstrate the wisdom and practical political judgement required of him by society while also influencing the future course of events. ${ }^{376}$ Such was the power of eloquence, in fact, that it raised the likes of Cicero from his modest origin to the highest office on the cursus honorum. ${ }^{377}$ Ultimately, it is by exercising virtus that one wins gloria. Actively participating in public life and achieving great deeds in the service of the state ensured individual celebrity. Like arete, this was a concept which insisted on externally recognized specific action. ${ }^{378}$ Only certain aristocratic deeds done in certain aristocratic arenas were considered worthy of praise. Such was the complex value system that Cicero had to convey in epistolary form. The statesman's distant addressees were not present to witness his noble defence of the res publica. Thus, he faced the difficult task of capturing his virtus and casting himself as Rome's saviour by way of correspondence.

\footnotetext{
${ }^{372}$ Hellegouarc'h (1963) 372.

${ }^{373}$ He uses a comparison between Themistocles' military success and Solon's law reform to illustrate his point.

${ }^{374}$ We see this expressed in terms such as dicendi gloria and gloria eloquentiae. See Hellegouarc'h (1963) 374; Tatum (2018) 168.

${ }^{375}$ Hölkeskamp (2013) 17. For a general overview of oratory and its complex role in late Republic politics see Blom (2016); Morstein-Marx (2004).

${ }^{376}$ Earl (1967) 34.

377 Tatum (2018) 168.

${ }^{378}$ Earl (1967) 35.
} 


\section{A Heroic Return}

In casting himself as the defender of the state, Cicero first had to refashion his initial exodus from and subsequent return to Rome. As examined in Chapter One, between April and August 44 BC, the elder statesman was at great pains to distance himself from the political conflict unfolding at the time. He took on the role of passive advisor in order to shift the burden of leadership and enhanced this ethos by physically separating himself from the city. ${ }^{379}$ Having left Rome on April 7, Cicero toured the Italian countryside for several weeks (Plut. Vit. Cic. 43; Cass. Dio. 44.23-33; Cic. Phil. 1.1) ${ }^{380}$ By the end of May, he was determined not to return to the city and regretfully entertained the idea of going to Greece (Att. 15.5.3). His hesitation about leaving Italy, however, was perhaps overplayed given that, earlier in the month, he had set out to secure a legateship which would legitimately remove him from the country (Att. 14.22.2). ${ }^{381}$ In any case, on August 6 Cicero's mind had been made up and he left Leucopetra for Greece (Att. 16.7.1). Though he failed to reach his destination on account of bad weather, the statesman was subject to much criticism for his intended departure. The Romans, as noted, tended to be hostile to statesmen who stepped away from the public eye. Because the public sphere was the only arena in which a noble could exercise his talents, when he withdrew, it seemed as though he was shirking his civic duties. ${ }^{382}$ Atticus was particularly judgemental, going so far as to charge Cicero with inconstantia and suggesting that he had forsaken his country by leaving it (Att. 16.7.3) ${ }^{383}$ The wider community, too, worried that he had deserted the res publica in its time of need and would not honour his pledge to return on the Kalends of January (Att. 16.7.5, 16.6.2). Moreover, that Cicero had planned to attend the Olympic games and perhaps take part in the Mysteries while the rest of Italy endured political uncertainty only served to exacerbate his already deteriorating public image (Att. 15.25.1, 16.7.7).

\footnotetext{
${ }^{379}$ Lintott (2008) 339.

${ }^{380}$ Leber (2015) 32. n. 35. See also Mitchell (1991) 295.

${ }^{381}$ Leber (2015) 34.

${ }^{382}$ Earl (1967) 23.

${ }^{383}$ Never mind that Atticus had actively supported his leaving in the first place, so Cicero claims (Att. 16.7.3).
} 
In order to remedy his reputation and take on a more authoritative role, Cicero needed to return to Rome and re-enter the civic arena. Only in the public eye could he exercise his virtus correctly and display the attributes of a true patriot. Here, the statesman draws on themes more reminiscent of Homeric arete to cast his return as a pseudo-supernatural event. ${ }^{384}$ It was as if Rome herself had called upon Cicero to fulfil his heroic destiny and defend the commonwealth. In a letter to Brutus he writes

But my spirit, anchored as ever upon the love of country, could not endure separation from her perils. Halfway to Greece, when the Etesians should have been blowing, the South Wind carried me back to Italy, as though dissuading me from my plan (ad Brut. 1.15.5).

And again to Cornificius he explains that

I was letting myself be carried off to Greece in a mood of anger against the times and despair of freedom, when the Etesian winds, like loyal citizens, refused to escort a deserter of the commonwealth and a contrary southerly gale brought me back to your fellow tribesmen of Regium (Fam. 12.25.3).

Cicero employs a distinctly Homeric grammar to create the impression that the storm had been no accident. In the epic tradition strong weather almost always acts as the instigator of a plot or is used to mark a critical moment in the narrative. ${ }^{385}$ More importantly, it is divine intervention made manifest. Natural forces are used by the gods to drive a hero towards his fate and ensure he is able to fulfil his epic objective; the winning of kleos ('glory') by way of arete. ${ }^{386}$ Take, for example, Odysseus. Throughout Homer's Odyssey the gods alternately still and rouse the winds to "interfere with the teleological programme of his nostos". ${ }^{387}$ Calypso blessed the hero with ouros - favourable wind — in order to help launch his ship from Ogygia and steer him home (Hom.

\footnotetext{
384 Leber (2015) 34.

385 Purves (2010) 327; Habicht (1990) 80.

${ }^{386}$ Purves (2010) 333. On kleos see Nagy (1979) chapters 1 and 6.

387 Purves (2010) 335.
} 
Od. 5.265-70). Even less than favourable weather, such as the tempest stirred by Poseidon to wreck Odysseus' vessel, urges him towards his destiny (Hom. Od. 5.285-314). Storms prompt various detours and deviations which ensure Odysseus does not achieve his nostos prematurely. ${ }^{388}$ Instead, he is forced to endure a series of conflicts and overcome foes as a result of his wanderings. Even when the favourable winds permit him to return home, his toils continue (Hom. Od. 1.1520). In fact, it is only upon his arrival in Ithaca that Odysseus faces his greatest threat- the suitors—and wins eternal glory by shrewdly besting them. ${ }^{389}$

Cicero evokes this Homeric motif in his own correspondence by personifying the Etesian and South winds. As mentioned, on August 644 BC, bad weather hampered his ship in the Straits of Messina. He was forced to return to his point of departure, Leucopetra, and wait until the wind was once more favourable (Att. 16.7.1, Fam. 12.25.3, ad Brut. 1.15.5, Phil. 1.8). Rather than attribute this setback to bad luck, however, Cicero offers up an altogether different reason. The adverse conditions he faced were a direct result of the res publica's desire to have him home (ad Brut. 1.15.5, Fam. 12.25.3) ${ }^{390}$ Just as Homer's gods used the weather to drive a hero towards his destiny, Rome herself stilled the Etesians and conjured the South Wind to ensure Cicero remained on his own fated course. He needed to return to the city in order to take a stand against Antony and win renown as the defender of libertas. Thus the Republic, through sheer will, set in motion a series of events which propelled the statesman to fulfil this purpose. Indeed, it was precisely because the weather halted him that an important message managed to reach Cicero from Rome (Att. 16.7.1). Brutus and Cassius, he was told, had issued an edict calling for a full meeting of the Senate on August 1 (Att. 16.7.1, Phil. 1.8). They reported high hopes that Antony would give way and a compromise allowing for the return of the Liberators and their supporters would be reached (Att. 16.7.1, Phil. 1.8). ${ }^{391}$ So too was the statesman provided with a copy of Brutus' and Cassius' manifesto (Phil. 1.8). ${ }^{392}$ Though its contents are unknown to us, Cicero was deeply impressed by

\footnotetext{
388 Purves (2010) 334.

${ }^{389}$ Finkelberg (1995) 8. On Odysseus' conflict with the suitors see e.g. Loney (2019).

${ }^{390}$ Habicht (1990) 80; Blom (2003) 202.

${ }^{391}$ Syme (2016) 197-8. In the First Philippic Cicero adds that this mention of compromise was likely an attempt on the part of the messenger to make the report more agreeable.

${ }^{392}$ Cicero does not make any mention of this manifesto in his letter to Atticus.
} 
their proposal and described it as "eminently fair" (Phil. 1.8). ${ }^{393}$ This news of the changing situation in Rome was most welcome. When combined with reports that people were beginning to criticize him for his absence, the statesman threw aside his plans to go to Greece and set a course for home (Att. 16.7.2; Phil. 1.8-9). Taken out of context, this volte-face risked casting Cicero as a time-server. However, because he generates a Homeric framework around which to fashion his return, the statesman instead casts himself in the role of epic hero. His noble destiny is so intertwined with the state's that, in a kind of pseudo-supernatural event, the res publica conspired with the South Wind to drive him towards Rome. ${ }^{394}$ Like Odysseus, however, upon return home the much-enduring Cicero faced a great struggle to re-establish himself in his own community. ${ }^{395}$

\section{The Epistolary Philippics}

The will of the Republic having carried him home, the elder statesman recognized that the time was right to re-enter the political arena and secure for himself a fresh position of authority. If Cicero was to assume the mantle of leadership, however, he needed to convince the Senate that Antony, like his predecessor Caesar, was striving for sole rule and represented a direct threat to the basic republican principle of libertas. ${ }^{396}$ Only by establishing the presence of danger could Cicero cast himself as a saviour. To achieve this would require an unparalleled demonstration of virtus and civic dexterity. Thus, on September $244 \mathrm{BC}$, Cicero summoned all of his oratorical skill to deliver the First Philippic before the Senate. The first in a series of fourteen speeches, the statesman used this performance to explain his absence (Phil. 1.8-11), criticise Antony for his misuse of Caesar's acta (Phil.1.16-18), challenge him to avoid the dictator's example (Phil. 3133, 36-38), and ultimately present himself as the patriotic champion of the res publica. ${ }^{397}$ Though

\footnotetext{
${ }^{393}$ Syme (2016) 200-1 proposes that the manifesto must have included an indication of their desire to surrender the corn-commission and return to Rome (rather than remain in exile, as others have suggested). ${ }^{394}$ Leber (2015) 34.

${ }^{395}$ Finkelberg (1995) 8. Cicero notably praises Odysseus' ability to endure hardship, especially upon return home to Ithaca where he was humiliated in his own home (Cic. Off. 1.113).

${ }^{396}$ Zarecki (2014) 146 . The concept of libertas will be addressed presently.

${ }^{397}$ Mitchell (1991) 301-2; Zarecki (2014) 145; Syme (1939) 140-144. For the depiction of Antony in the First Philippic see Stevenson (2009). For a general overview of Cicero's Philippics see Wooten (1983); Stevenson \& Wilson (2008); Hall (2002); Dugan (2005) 333-344
} 
critical, the oration was also carefully conciliatory. Cicero made sure to avoid personally attacking Antony so as to remain within the bounds of amicitia and avoid "commit[ing] himself to an irreparable feud". ${ }^{398}$ His tone, however, quickly changed. Antony had reacted badly to the First Philippic and, in a scathing attack on the elder statesman's career, declared himself to be Cicero's enemy (Phil. 5.18-20). ${ }^{399}$ As a result, Cicero responded with his Second Philippic. Presented in a pamphlet, this was a sustained and bitter onslaught in which he catalogued Antony's shortcomings and the various atrocities he had committed in his lifetime. ${ }^{400}$ From here came the Third Philippic, delivered before the Senate on December 20, and the Fourth Philippic, performed in a public meeting on the same day. It was with these two orations that Cicero irrevocably cut ties with Antony and embarked in earnest upon an intense contest for supremacy (Fam. 12.24.2, 12.25.2; 10.28.2). ${ }^{401}$ The ten Philippics that followed were similarly dominated by a combination of Cicero's personal experience, his political expertise, the repetition of key themes, philosophical ideas, and of course invective. ${ }^{402}$ These attacks were ultimately designed to present Antony as the tyrant who had enslaved the Republic and therefore ravaged its political liberty (Phil. 2.70; 3.29; $3.34 ; 5.54 ; 10.12 ; 12.14 ; 13.32) .{ }^{403}$ Cicero characterised the post-Ides crisis as a conflict between the entire Republic and a single hostis (Phil. 3.1; 4.14-15; 5.32; 7.7-8; 13.38-39). ${ }^{404}$ This way, when he finally removed Antony—-be it by exile or death—the whole community would applaud him as the saviour of the res publica. ${ }^{405}$

A confident, persuasive, and self-promotional display of virtus, the Philippics were fundamental to Cicero's self-fashioning as the commonwealth's defender. Unfortunately for him,

\footnotetext{
${ }^{398}$ Syme (1939) 140. According to Cicero's De Amicitia, it is a friend's duty to point out his friends flaws (Amic. 89). See also Mitchell (1991) 301-2.

399 The senate met on September 19 in the Temple of Concord, which Antony had surrounded with his soldiers. It was there that he delivered his invective to an absent Cicero (Phil. 5.18-19).

${ }^{400}$ Shackleton Bailey's 'Introduction' to his translation of the Second Philippic usefully unpacks Cicero's thematic and rhetorical programme. See Shackleton Bailey (2010) 49-53.

${ }^{401}$ Shackleton Bailey (2010) 50.

${ }^{402}$ Zarecki (2014) 146; Stevenson (2008) 104. For a brief overview of the content of each oration see Hall (2002) 274-283.

${ }^{403}$ On Antony as tyrant and a threat to libertas see e.g. Plut. Ant. 15.4; Vell. 2.61.1; Stevenson (2008); Zarecki (2014) 145-154; May (1988) 148-161; Tatum (2020); Hall (2013) 223-4.

${ }^{404}$ Shackleton Bailey (2010) xxv-xxvi.

${ }^{405}$ Zarecki (2014) 145.
} 
a number of his correspondents were not present in Rome to witness his patriotic performances in action; Decimus was in Gallia Cisalpina acting as proconsul, Brutus and Cassius were amassing support in the east, Plancus was governing Gallia Comata, and Cornificius held Africa Vetus. ${ }^{406}$ While it is reasonable to assume many received direct transcripts of the orations, Cicero was also at great pains to reproduce their key themes, rhetorical devices, and invective tropes in the letters themselves. ${ }^{407}$ In particular, he replicates from the Philippics what Cecil Wooten as termed the 'disjunctive mode' to set himself in direct opposition to Antony. ${ }^{408}$ Characteristic of the 'rhetoric of crisis', the disjunctive mode is the method by which an orator juxtaposes fundamentally opposing systems in order to present his audience with two mutually exclusive options, one of which is clearly the superior choice. ${ }^{409}$ In his correspondence, the statesman creates this contrast between himself and Antony by using slavery and freedom as a model. This binary is one that is fundamental to the Roman conception of political liberty. Libertas, in its simplest form, is the absence of slavery and it designates a citizen's right to be free from interference by the arbitrary will of a third party (Cic. Par. 5.34; Phil. 6.19; Plan. 16; Caes. BGall. 3.10; Livy, 2.15.3). ${ }^{410}$ Indeed, the very essence of the res publica is intrinsically linked to libertas by way of divine law. Rome is destined to rule over all nations; therefore, the enslavement of its people goes against the cosmic order (Phil. 6.19). By casting Antony as the tyrant who has subjugated the state, then, Cicero characterizes him as the ultimate threat to the res publica. More importantly, where there is a villain, there is a hero. The creation of a despotic Antony naturally generates a comparison with Cicero, the architect of the nefarious persona ${ }^{411}$ As a result, the statesman becomes the morally superior antithesis of Antony. Cicero exhibits the qualities of virtus which Antony does not and ultimately is able to fashion himself as Rome's saviour. ${ }^{412}$

\footnotetext{
${ }^{406}$ Syme (1939) 162-175 provides an excellent summary of the whereabouts of key magistrates between 44 and $43 \mathrm{BC}$.

407 At the very least, Brutus and Cassius certainly received copies of the Philippics (ad Brut. 2.3.4, 2.4.2; Fam. 12.2.1).

408 Wooten (1983) 58

${ }^{409}$ Wooten (1983) 58. See also May (1988) 149; Hall (2002) 283-4.

410 Balmaceda (2020) 33-4; Ando (2020) 104; Arena (2020) 72. See also Arena (2012).

${ }^{411}$ Zarecki (2014) 147. On the concept of libertas in Cicero's Philippics see Cowan (2008).

412 Zarecki (2014) 147.
} 
A tyrant, according to Cicero, is a man who aspires to pre-eminence and absolute power without consideration for the constraints imposed by laws, social expectations, or self-control (Cic. Off. 1.64, 3.32, 3.83; Rep. 1.64ff, 2.47-9). ${ }^{413}$ As a stock figure in Roman invective, the characterisation of a tyrant requires a network of recurring imagery, behaviours, and terminology. ${ }^{414}$ Typically, because of his unchecked power and lack of restraint, he is depicted as embodying the core attributes of crudelitas, libido, superbia, and vis. ${ }^{415}$ So too is he susceptible to women, impiety, gluttony, and drunkenness. ${ }^{416}$ In convincingly casting Antony as a tyrant, Cicero faced a major obstacle. Having been hand-picked by Caesar to be his consular colleague, Antony was shielded by the legitimacy of his consulship. ${ }^{417}$ He had a valid claim to executive authority and even exercised it well by playing a critical role in the 17 March Amnesty (Phil. 1.1, 31; 2.89; Att. 16.14.1; App. B Civ. 2.142-3; Cass. Dio. 44.22.3, 46.28.3). ${ }^{418}$ To navigate this, Cicero asserts that, despite Antony's praiseworthy statesmanship, it took only a short time for him to engage in conduct that resembled an illegal seizure of power. ${ }^{419}$ That is, the consul had quickly taken to abolishing already established laws and manipulating the acta in Caesar's unpublished memoranda for his own gain (Phil. 1.12-26; Cass. Dio. 44.53; Plut. Vit. Ant. 15; App. B Civ. 3.5). ${ }^{420}$ Cicero reveals in a letter to Cassius that, under Antony, "laws are posted up, exemptions are granted, large sums of money are assigned, exiles are brought home, and decrees of the Senate are forged" (Fam. 12.1.1). What is more, he details for Atticus two specific abuses of power. In return for a generous bribe, Antony forced through a lex by which the Sicilians were granted full Roman citizenship; he similarly decreed that king Deiotarus was to regain the territory initially taken from him by Caesar (Att. 14.12.1). ${ }^{421}$ Notably, this charge of manipulating established

\footnotetext{
${ }^{413}$ Lessie (2015) 74. For an excellent survey of ancient tyranny—both Greek and Roman—and the way in which it influenced political thought and culture see Lewis (2006).

${ }^{414}$ Both Dunkle (1967) and more recently Stevenson (2008 \& 2009) have done important work on the tyrant as a stock figure in Roman invective.

${ }^{415}$ Lessie (2015) 74; Dunkle (1967) 151-2.

${ }^{416}$ Dunkle (1967) 160-171.

${ }^{417}$ Zarecki (2014) 146; Lessie (2015) 76.

${ }^{418}$ See Christian (2008) for the philosophical obstacles that Cicero faced in casting Antony as a despot.

${ }^{419}$ Lessie (2015) 77.

${ }^{420}$ Lessie (2015) 77. See also Ramsey (1994).

${ }^{421}$ Ramsey (1994) 141.
} 
legislation is a conventional topos of the stock tyrant. ${ }^{422}$ It signals total disregard for the restraints imposed by the law and is therefore an expression of despotic aspiration.

To further substantiate this image of Antony as tyrant in his correspondence, Cicero reproduces the conventional language of despotic gluttony, excess, and madness that he employed in his Philippics. Specifically, he accuses the consul of drunkenness. ${ }^{423}$ Rhetorically, intoxication falls under the charges of overindulgence (luxuria) and lack of restraint (temperantia, contentia, or incontinentia) (Cic. Inv. rhet. $1.22 ; 2.164 ;$ De or. $1.56 ; 2.67 ; 2.131) .{ }^{424}$ It signals a total diversion from the poise, dignity, and good judgement which defines the aristocracy and marks the beginning of a descent into moral—and therefore political—crisis. ${ }^{425}$ Antony himself was a notorious drunkard (e.g. Cic. Phil. 2.6, 31, 42, 62-3; Plut. Vit. Ant. 9; Sen. Ep. Mor. 83.25; Cass. Dio. 45.6). His inebriated exploits, as Hall notes, provided Cicero with the "rich material" he needed to generate a caricature of the consul as unrestrained, repugnant, and foolish; a man wholly undeserving of respect. ${ }^{426}$ Thus, writing to Cornificius, Cicero characterises Antony as a "belching, vomiting brute" who has been swept up in a "drunken fury" (Fam. 12.25.4). He similarly jokes to Cassius that, during one of Antony's speeches, "everyone thought he was not speaking but vomiting — according to habit!" (Fam. 12.2.1). Cicero here is alluding to an anecdote developed more fully in his Second Philippic. The statesman tells of a hungover Antony who, having ingested excess food and wine at a wedding the night prior, "vomit[ted] in full view of the Roman people" (Phil. 2.63). ${ }^{427}$ It is a vulgar episode which Cicero uses to symbolise the consul's proclivity for overindulgence and unrestrained consumption on a grander scale. ${ }^{428}$ Beyond excessive alcohol consumption, Antony's vomiting represents his despotic luxuria; an excessive desire for wealth, women, and worst of all, power. Cicero employs this crude imagery to divest

\footnotetext{
${ }^{422}$ Lessie (2015) 77 n. 109. Lessie points to ps.-Sallust's In Ciceronem 3.5 as an example of this topos in use. In charging Cicero with tyrannical conduct during his consulship, the author criticises him for annulling the Porcian law and blatantly manipulating other legislation to suit his own needs.

${ }^{423}$ The Second Philippic contains the best examples of this invective topos (gluttony and drunkenness). See Phil. 2.6, 31, 42, 62-3, 75, 77, 81, 84, 87, 104-5.

${ }^{424}$ See Craig (2004) 191 for a useful table of invective topoi.

${ }^{425}$ Mortensen (1999) 19.

${ }^{426}$ Hall (2002) 288-9.

${ }^{427}$ Other mentions of Antony vomiting in the Second Philippic occur at Phil. 2.50, 76, and 84.

${ }^{428}$ Mortensen (1999) 38-9.
} 
him of consular dignity. ${ }^{429}$ A man who cannot control his own bodily functions is certainly not capable of controlling the state. At the same time, Antony's virtus is called into question. Surrendering to one's appetites, according to Aristotle, is evidence of inadequate aretē, for a man under the influence of unchecked passion will consistently go against reason (Arist. Eth. Nic. $7.1145 \mathrm{~b} 4-1146 \mathrm{~b} 12){ }^{430}$

Finally, Cicero concludes that, though the Liberators had "driven away a great plague" when they assassinated Caesar, the "apparatus of monarchy descended to Antony" (ad Brut. 1.15.4). Brutus, Cassius, and their partisans had left the job half-done and as a result Rome was enslaved to a "crazy desperado, far more wicked than even he whom you called the wickedest man ever killed" (Fam. 12.21.1). Cicero here casts Antony as the tyrant par excellence by highlighting that his conduct is even worse than Caesar's. ${ }^{431}$ This is a theme which likewise occurs throughout the Philippics. In the Fifth Philippic, for example, Antony is situated against a procession of historical despots; Cinna, Sulla, and Caesar (Phil. 5.17). While each of these three figures had in the past exercised extraordinary monarchic authority over Rome, it is Antony who surpasses all of them for he is the only man shameless enough to openly parade his armed guard in the city (Phil. 5.17; Phil. 2.108). ${ }^{432}$ Cicero's blatant characterisation of Antony as the state's most deplorable tyrant serves two distinct purposes. On the one hand, it signals that he is beyond worthy of removal from power. Past ancestors were justified in exiling, or even murdering those guilty of tyranny, therefore, the present expulsion of Antony-who is demonstrably worse than previous despots - is all the more justified. ${ }^{433}$ On the other hand, by devolving the consul's ethos to be one of unparalleled lawlessness, drunkenness, and unrestraint, Cicero creates for himself the ideal foil. ${ }^{434} \mathrm{He}$ is able to situate himself in direct opposition to Antony by exhibiting the qualities

\footnotetext{
${ }^{429}$ Hall (2002) 289. See May (1996) 145-7 for Cicero's fashioning of Antony as not just un-consular, but inhuman.

${ }^{430}$ Arist. Eth. Nic. 7.1-10 discusses akrasia. On virtus and self-restraint in Rome see Edwards (1993).

${ }^{431}$ Lessie (2015) 72. On unflattering comparison as a rhetorical device to undermine Antony in the Philippics see Welch (2008) 212-3.

${ }^{432}$ Lessie (2015) 98 notes that Cicero uses that adjective unus to stress Antony's "exceptionalness and isolation".

${ }^{433}$ Lessie (2015) 81.

${ }^{434}$ May (1988) 149-160; Zarecki (2014) 147.
} 
of virtus he so clearly does not possess. What is more, there is prestige in having a formidable foe. ${ }^{435}$ Cicero would win more gloria from defending the res publica if the threat was a truly dangerous one.

Thus, having established the deplorability of Antony's character in his correspondence, Cicero casts himself as his antithesis. He begins by chronicling for Cornificius the delivery of the First Philippic, writing

From there I hastened back to my country as fast as sail and oar could take me, and the day after my arrival I was the only free man in an assembly of abject slaves. I delivered an attack upon Antony which was more than he could stand. So he poured out all his drunken fury on my single person... (Fam. 12.25.4).

Immediately evident is Cicero's use of the 'disjunctive mode' to create contrast between himself and Rome's leading body of men, all of whom have been enslaved by their despotic consul. ${ }^{436} \mathrm{In}$ particular he uses the adjective unus to stress his exceptionality as the sole statesman who is still free. It is important to note here that libertas does not only represent opposition to slavery or domination by an external force, it also signifies an "internal freedom", the state in which one's spirit is unmarred by corruption and immorality. ${ }^{437}$ This inner libertas, moreover, pertains to virtus. That is, according to Catalina Balmaceda, more than just the bravery shown in a public arena, virtus represents "the courage to live a virtuous life in spite of the opposition of one's enemies" (Enn. Phoenix, fr. 109). ${ }^{438}$ Cicero, then, is a free man because his unparalleled fortitude guards his spirit against Antony's vice. This in turn means he alone possesses the necessary virtus to take on the tyrant and liberate the rest of Rome from its state of slavery. He launches his attack in the form of the First Philippic and, according to the letter, it was highly successful. Indeed, Cicero uses Antony's negative response to strengthen the impression of his virtus. Because a

\footnotetext{
435 On the Roman attitudes towards inimicitia see Epstein (1987) 12-19.

${ }^{436}$ Wooten (1983) 58.

${ }_{437}^{43}$ Balmaceda (2020) 48.

${ }^{438}$ Balmaceda (2020) 48 provides a translation of the fragment: "It is proper for a man to live inspired by true valour (virtus) and to stand against adversaries strong and blameless; it is freedom (libertas) when bears a pure and steadfast heart; all else is servile, hidden in the darkness of night".
} 
Roman aristocrat was judged by his ability to overcome rivals, enmity (inimicitia) was an important measure of a man's status. ${ }^{439}$ In particular, anyone willing to endure hostility for the sake of the state was identified as self-sacrificing and worthy of glory (Cic. Sest. 139). ${ }^{440}$ Cicero stresses in his letter that he alone-unus—-bore the brunt of Antony's malice following his speech (Fam. 12.25.4). By doing so he not only emphasises the effectiveness of the First Philippic as an assault on the consul, but he casts himself as a selfless advocate; someone whose devotion to the state means he is prepared to defend it no matter the personal consequence.

While the First Philippic marked an important first step, as noted above, the Third Philippic was a demonstration of virtus instrumental to Cicero's self-fashioning as Rome's saviour. The speech itself was primarily used by the orator to establish the positions of each key player in the conflict; he outlined Antony's deplorable behaviour (Phil. 3.15-27), sang the praises of his opponents (Phil. 3.3-14), and described the necessary next steps to take immediate action against him (Phil. 3.28-36). ${ }^{441}$ Cicero moved that Decimus and all other provincial governors be allowed to retain their provinces at the disposal of the res publica until a suitable successor could be appointed to each (Phil. 3.38). At the same time he proposed that Octavian, his veterans, and those who had defected to him from Antony be honoured for their defence of the Republic (Phil. 3.38-9). The Senate passed his motion and, in doing so, both invalidated Antony's own allocation of consular provinces to himself and Dolabella, and effectively sanctioned private resistance against the soon-to-be ex-consul (Phil. 4.1-9). ${ }^{42}$ Thus, with the Third Philippic, Cicero had irrevocably cast himself as defensor and conservator of libertas in direct opposition to Antony (Phil. 3.28). ${ }^{443}$

\footnotetext{
${ }^{439}$ Epstein (1987) 21-23.

${ }^{440}$ Epstein (1987) 23.

${ }^{441}$ Shackleton Bailey (2010) 175-6; Zarecki (2014) 150; Tempest (2014) 196.

${ }^{442}$ Shackleton Bailey (2010) 175; Tempest (2014) 196.

${ }^{443}$ Zarecki (2014) p. 150.
} 
The statesman reflects on the significance of the speech in a number of letters. To

Cornificius, for instance, he explains that

On the first occasion that presented itself to defend the commonwealth in my old style, I offered myself to the Senate and People of Rome as their leader and, since I first took up the cause of freedom, I have not let slip the smallest opportunity to champion our corporate existence and liberties (Fam. 12.24.2).

A key phrase here is 'in my old style' and it is one echoed by Cicero in a similar letter to Trebonius when he recalls December $2044 \mathrm{BC}$ as the day "my old spirit returned to me" (Fam. 12.28). He is of course referring to his famous suppression of the second Catilinarian conspiracy while consul in 63 BC. Having uncovered a plot to overthrow both himself and his consular colleague Gaius Antonius Hybrida, Cicero had launched an accusatory attack on Catiline in a series of four speeches known as the Catilinarians (Plut. Vit. Cic. 22; Sall. Cat. 31.6; Diod. Sic. 40.5a). ${ }^{444}$ These orations were important, both for the way they portrayed the conspirators and for their characterisation of the statesman who delivered them. Catiline was cast as a crime-breathing monster who threatened Rome with destruction by fire and sword (Cic. Cat. 1.2-3; 2.1; 2.6). ${ }^{445}$ Indeed, so depraved and immoral was his character that he, along with the other conspirators, had relinquished his right to Roman citizenship (Cic. Cat. 2.15). ${ }^{446}$ By virtue of the disjunctive mode, Cicero's ethos represented the opposite. He was the noble consul who had single-handedly driven away the Republic's greatest threat (Sull. 33; Phil. 6.17-8; 14.141 Plut. Vit. Cic. 22.6). ${ }^{447}$ In particular, the statesman fashioned himself as dux togatus or 'toga-clad general' (Cat. 3.23). ${ }^{448}$

\footnotetext{
${ }^{444}$ For an excellent introduction to the second Catilinarian conspiracy and literary analysis of Catilinarians 1-4 see Berry (2020).

${ }^{445}$ Dugan (2005) 51-52; Hall (2002) 286-7. On Cicero and his portrayal of his political enemies as monstrous and inhuman see May (1996).

${ }^{446}$ Dugan (2005) 52.

${ }^{447}$ Dugan (2005) 52; May (1988) 160-1; Blom (2003) 302 n. 64.

${ }^{448}$ As Hall (2013) 217 notes, the paradoxical imagery generated by the term dux togatus is important to acknowledge in order to understand its significance. Before a magistrate could depart from Rome as the $d u x$ or commander of an army, he first had to ritually exchange his toga (a garb of peace and civil life) for military dress (e.g., Livy $21.63 .9 ; 27.40 .7 ; 31.14 .1)$. The image of a toga-clad military commander, therefore, is one that is unique.

For Cicero as dux togatus see also May (1988) 56, 158; Cape (2002) 148.
} 
This gave him licence to claim gloria as a successful military commander who had triumphed in a war of virtue against vice without resorting to armed violence. ${ }^{449}$ Rather, it was by exercising sound judgement and oratorical excellence before the People and the Senate of Rome that he alone had saved the res publica from extinction at Catiline's hand and won renown as a result (Cic. Cat. 2.14-5). Ultimately, Cicero's consulate was, as he understood it, a "divine performance" of virtus. ${ }^{450}$ It was the period in which he most effectively used his eloquence to accumulate wide consensus and achieve his ideological and political aspirations. ${ }^{451}$ When he writes of delivering the Third Philippic in his 'old style' and with his 'old spirit', then, Cicero reminds his correspondents of his past service to the state and the exceptional personal achievement that was his defeat of Catiline. What is more, by evoking his consular legacy the statesman signals that he has reprised his role as dux togatus and is prepared once again to use his talents to defend the commonwealth from the threat that the new Catiline now poses to its existence (Phil. 2.118). ${ }^{452}$

Cicero more explicitly revives his consular persona by using epistolary slogans of leadership and liberty. As seen above, he claims that, by delivering the Third Philippic, he had selflessly offered himself up as princeps of the res publica (Fam. 12.24.2) and "brought to the Roman people the first hope of recovering their freedom" (Fam. 10.28.1). ${ }^{453}$ Just as he had done twenty years prior, Cicero, out of sheer devotion to the state (and a profound desire for glory) is once again guiding Rome to safety with his courage, wisdom, and oratorical skill. ${ }^{454}$ He takes this rhetoric a step further by positioning himself as the helmsman of the Senate. The statesman beseeches Cornificius to

\footnotetext{
${ }^{449}$ May (1988) 56; Cape (2002) 148; Hall (2013) 217.

${ }^{450}$ Habicht (1990) 33-4.

${ }^{451}$ Vasaly (2013) 158.

${ }^{452}$ Dugan (2005) 333-9; Tempest (2014) 196; Hall (2002) 293; Berry (2020) 89-90; May (1988) 160-1.

${ }^{453}$ Other terms that Cicero later used to describe his position of power include principatus (Phil. 14.17-18), dux (ad Brut. 1.2a.3), and auctor (Phil. 4.16). See Stockton (1971) 303.

${ }^{454}$ Stockton (1971) 297; Tempest (2014) 196; May (1988) 160-1.
} 
... come aboard with us and stand at the poop. All honest men are now in the same boat. I am trying to keep her on course, and I pray we have a fair voyage. But whatever winds may blow, my skill shall not be wanting. What more can virtus guarantee? (Fam. 12.25.5).

The imagery here immediately recalls Cicero's recurrent metaphor of the orator as the ideal helmsman (gubernator) who steers the ship of state (e.g. Cic. Sest. 15, 20, 45-6; De or. 1.8, 1.46, 1.214; Rep. 1.62; Att. 1.1.5, 8.11.1). ${ }^{455}$ As elaborated in his De Oratore, Cicero believed the orator was of universal value to the civic stability of Rome (Cic. De or. $1.31-4) .{ }^{456} \mathrm{He}$ argued that the eloquence, practical judgement, moral wisdom, and humanitas of trained orators made them the ideal candidates to determine public policy and guide the Republic towards success (Cic. De or. $3.63,122) .{ }^{457}$ What is more, the speaker is an antithesis to the military general; rather than resort to armed violence, he employs his skill in persuasion to facilitate peace (Cic. De or. 1.210-13; 2.84; Off. 1.75-6). ${ }^{458}$ For this reason, orators "by their counsel and wisdom could control and direct the helm of the state" (Cic. De or. 1.8). ${ }^{459}$ His description of the ideal orator in De Oratore, John Dugan notes, is a clear revival of the dux togatus role he had established for himself as consul in 63 BC. ${ }^{460}$ Now, following Caesar's death, the statesman once more embodies this ethos by becoming gubernator. This time, however, he lacked the validation of an official magisterial position. To compensate, Cicero uses virtus as a political slogan to legitimize his authority and convince his correspondents to board his ship. ${ }^{461} \mathrm{He}$ assures Cornificius that, on account of his unparalleled devotion to the state, there is no one more suited to take the helm and unite the Senate against Antony.

\footnotetext{
${ }^{455}$ Vasaly (2013) 155. On the ship-of-state metaphor see May (1988) 91-2, 95-7, 99-101, 105.

${ }^{456}$ Dugan (2013) 31. On the ideal orator in De Oratore itself see Dugan (2005) 75-171

${ }^{457}$ Fantham (2004) 313; Dugan (2013) 31; Vasaly (2013) 154-5.

${ }^{458}$ Dugan (2013) 31.

${ }^{459}$ Translation by Sutton \& Rackham (1942).

${ }^{460}$ Dugan (2013) 31.

${ }^{461}$ On the use of virtus as a political slogan see Balmaceda (2017) 37. See also Kenty (2020) 147-51 on Cicero's revival of the Senate in his Philippics.
} 


\section{Princeps Sumendorum Sagorum}

Despite the policy of peace that Cicero had long promoted as dux togatus, his commitment to the defence of the res publica against its most vile foe ultimately required him to don the cloak of war (sagum) (Phil. 12.17). ${ }^{462}$ He admitted in a letter to Brutus that he no longer believed in the effectiveness of oratory as a foil to Antony's antagonism (ad Brut. 2.5.1) Instead, he would pursue glory as Rome's saviour by exercising virtus more reminiscent of that demonstrated in the martial arena. That is, with what Syme labelled "fanatic intensity", Cicero rejected the notion of compromise with his enemies and instead promoted the necessity for extra-legal measures and total war. ${ }^{463}$ Success in this campaign for the armed suppression of Antony rested on Cicero's self-positioning as someone from whom his addressees - influential military generals—could receive legitimacy. ${ }^{464} \mathrm{He}$ begins fashioning this authoritative ethos by imploring his correspondents not to wait for senatorial support before engaging in private resistance (privatum consilium) on behalf of the res publica (Fam. 11.7.2-3; 12.7.2; 10.16.2). ${ }^{465}$ Because it is not yet liber, the Senate is unable to formally express its approval of the anti-Antonian cause through official sanction. Rather, Cicero tells Decimus, "the will of the Senate should be accepted in lieu of authority when its authority is trammelled by fear" (Fam. 11.7.2-3). ${ }^{466}$ That is, regardless of legality, the Liberator should do everything in his power to defend Rome against Antony because this is what the governing body would decree if it was in a position to do ${ }^{40}{ }^{467}$ By promoting this fiction that the post-Ides Senate is a "monolithic, harmonious entity" capable of consensus, Cicero is able to cast himself as its mouthpiece. ${ }^{468}$ He relays to Brutus that

\footnotetext{
462 Dugan (2005) 339-40.

${ }^{463}$ Syme (1939) 140-8 was particularly critical of Cicero's stand against Antony. He regarded it as a desperate attempt in the late stages of life to make up for past humiliations. On Cicero's advocacy for privatum consilium as a means of defending the state see Hodgson (2017) chapter 6. See also Tempest (2014) 195; Blom (2003) 309.

${ }^{464}$ Kenty (2020) 147.

${ }^{465}$ Hodgson (2017).

${ }^{466}$ Italics my own.

${ }^{467}$ Hodgson (2017) 257.

${ }^{468}$ Kenty (2020) 147. See also Hodgson (2017) 257.
} 
it is the feeling of the Senate and of the People of Rome that no public enemies ever deserved the harshest penalties more than those Romans who have taken up arms against their country in this war (ad Brut. 13.3.3)

Cicero's encouragement to take up arms against Antony is evidently in alignment with what he has presented as the Senate's desire for retribution. It follows, then, that his extra-legal measures could be understood to have a colour of legitimacy. ${ }^{469}$ This authoritative self-fashioning reaches a head when the statesman declares that, inspired by his counsel, the young Octavian had raised a private army (ad Brut. 1.15.6). Here, Cicero himself becomes "the ultimate source of this private war". ${ }^{470}$

Finally, Cicero's martial ethos is perhaps most conspicuous in his correspondence to Brutus. The Liberator was fiercely opposed to his war-mongering and, as a result, Cicero worked hard to defend his self-positioning (ad Brut. 1.2a; 1.15; 1.4). Take, for instance, his response to Brutus' call for lenience

My general political aims have always been identical with yours, my dear Brutus; my policy in certain matters (not all) has perhaps been a little more forceful. You know I have always held that the commonwealth should be freed from monarchy, not merely from a monarch. You took a milder view, no doubt to your eternal credit (...) In the present situation, what is to be done my friend? What is at issue in this war is our existence, no more, no less (ad Brut. 2.5.1, 5).

The statesman begins by emphasising that his bellicose persona is situated entirely within the bounds of his constantia. ${ }^{471}$ As we know, throughout his political career Cicero has persistently and demonstrably opposed any threat to the libertas of the res publica, always with peace as his objective. ${ }^{472}$ Now, because Brutus and his partisans have failed to rid Rome of a most vile tyrant,

\footnotetext{
${ }^{469}$ White (2010) 162.

${ }^{470}$ Hodgson (2017) 258

${ }^{471}$ On constantia as one of Cicero's guiding moral and philosophical principles see Tracy (2012).

472 Mitchell (1991) 307.
} 
Cicero maintains that his own constantia compels him to campaign for war. ${ }^{473}$ That is, to his mind, advocacy for the violent suppression of Antony is not inconsistent with his historical promotion of peace or his identity as a noble saviour. ${ }^{474}$ Though his means may have changed, his ideological end - the one he shares with Brutus - has not. Cicero is thus perfectly justified in his donning of the sagum. Moreover, Cicero emphasises to Brutus that his martial ethos is necessary for the state's survival. Antony, with his oppressive aim to power, lack of self-control, and blatant disregard for the law, represented the most dangerous type of threat to Rome (e.g. Cic. Phil. 2.70; $3.29 ; 3.34 ; 5.54 ; 10.12 ; 12.14 ; 13.32) .{ }^{475} \mathrm{He}$ was intent on destroying the res publica and achieving personal domination. The statesman amplifies this danger by casting the conflict between Antony and the Senate as a fight for survival, one which Brutus' policy of clemency could not win (ad Brut. 2.5.5; 1.2a.2; 1.15.10-11). ${ }^{476}$ Instead, it is Cicero who will defend the state through a campaign of fearlessness, retribution, and martial influence. Years prior, in the First Catilinarian, he had lamented the loss of "that virtus that used to be found in this Republic and caused brave men to suppress a citizen traitor with keener punishment than the most bitter foe" (Cic. Cat. 1.3). ${ }^{477}$ It seems that now, in his post-Ides search for authority and renown, Cicero is reviving this bygone virtus to take on his greatest adversary and fashion himself as Rome's saviour.

\section{Summary}

In his pursuit of post-Ides influence, it is by demonstrating elements of arete and virtus that Cicero constructs an essential epistolary persona. While he had worked hard to secure authority as an adviser and amicus, the only way to guarantee universal recognition was to win glory through unparalleled service to the state. Thus, Cicero fashions himself as the defender of libertas against the tyrant Antony. Because this was a conflict largely centered in Rome, however, the statesman

\footnotetext{
${ }^{473}$ Fulkerson (2013) 261. Grabarek (2010) 140 notes that this is also in part a rhetorical device to exaggerate the degree of danger the Antony presented. For the peace-loving Cicero to compelled into a desire for armed warfare must mean the res publica has encountered a truly monstrous foe.

${ }^{474}$ Mitchell (1991) 307.

${ }^{475}$ Mitchell (1991) 308.

476 Lämmle (2017) 34.

477 Translation by Macdonald (1976).
} 
faced the challenge of conveying his performance of virtus to distant correspondents. To begin, he carefully characterizes his return to the city as a pseudo-cosmic event; while on his way to Greece, the will of the Republic steered him home with a storm and set him on his fated path against Antony. Cicero's use of Homeric imagery here evokes the arete of those epic heroes whose excellence and fortitude has won them eternal renown. Once in Rome, the statesman irrevocably casts himself in opposition to Antony by way of his Philippics. A display of eloquence, civic fortitude, and patriotism, these speeches epitomized Cicero's virtus and were thus essential to his role as saviour. To convey this ethos to his absent addressees, he recreates the Philippics in epistolary form. Employing the disjunctive mode, the statesman devolves Antony's character in order to cast himself as the antithesis. So too does Cicero revive his consular persona as a means of reinforcing his self-positioning as the defender of libertas. Finally, he embodies the general, exercising virtus reserved only for the martial arena. Each of these performances of virtus is designed to illustrate Cicero's dedication to the greater good and the well-being of the community. By selflessly opposing a tyrant, he establishes himself as the saviour Rome and, in turn, wins recognition as the post-Ides helmsman. 


\section{$\underline{\text { Conclusion }}$}

Caesar's murder on the Ides of March 44 BC triggered a power vacuum that no one man was in a position to fill. Though he had perhaps established some semblance of control on March 17, the now elderly Cicero lacked the necessary magisterial authority to direct affairs and his influence over the fractious Senate was fragile. So too did he face the challenge of physical distance. With influential statesmen scattered across the Roman world, the reliance on correspondence for political manoeuvring was more pronounced than ever. Cicero's letters, then, played an essential role in his self-fashioning of authority in the wake of Caesar's assassination—as demonstrated by an assessment of epistolary ethos within the post-Ides corpus. When employed as a lens, Aristotle's conception of ethos as comprising phronesis, eunoia, and aretē illuminates a series of calculated personae curated by Cicero to achieve his ultimate rhetorical objective, a fresh position of influence as the helmsman of the res publica during its time of crisis.

Adopting phronesis as a framework reveals how the statesman employed wisdom, good sense, and prudence within the correspondence to fashion himself as a new Nestor. Unable to secure authority on the basis of military proficiency or an official magistracy, Cicero sought to steer the state indirectly by dispensing sound advice and becoming an exemplum for his younger addressees to follow. What is more, the same themes of sagacity and practical experience which he had used to curate his Nestor persona were also instrumental in fashioning an ethos of withdrawal; the statesman positioned himself as a senex simply too old to take charge. An assessment of phronesis in the post-Ides correspondence, then, demonstrates how Cicero's careful self-fashioning permitted him to maintain influence over affairs as an authoritative advice-giver while transferring the burden of leadership to his younger, more energetic addressees.

Next, uniting the fractured Senate under a single republican cause demanded the diligent forging of alliances. Analysing the letters through the lens of eunoia highlights Cicero's selffashioning as an amicus in order to secure the loyalty of, and therefore have influence over, one particularly valuable Caesarian, Plancus. He cultivated this bond by exhibiting the three facets of rhetorical benevolence. The first — unconditional goodwill — Cicero conveyed by casting himself 
as a father-figure, the second — praise and approval— he provided by applauding Plancus' acts of patriotism, and lastly — a readiness to help — was demonstrated through promises to promote his addressee's dignitas. This sustained performance of benevolence allowed Cicero to cast himself as an amicus in an effort to bind addresser and addressee in a web of mutual obligation. Ultimately, examining eunoia in the post-Ides corpus elaborates on important work done by Hall (2009) to reinforce the fundamental role of goodwill and affection in Cicero's epistolary selffashioning of authority.

Finally, in order to secure universal recognition as a leading figure in Rome, the elderly statesman fashioned himself as the defender of libertas. It is with arete and its Latin equivalent virtus as a lens that Cicero's persona as the res publica's saviour is elucidated within the correspondence. First, he recreated the reality of his virtue by casting his return to the city in a Homeric light. In doing so, Cicero evoked the arete of epic heroes and established that his imminent conflict with Antony was one of cosmic significance. The Philippics, an unparalleled display of civic fortitude, were fundamental to his self-fashioning as Rome's defender. Thus, he reproduced his performance within the letters by positioning himself as the antithesis to Antony's tyranny. So too did he don the sagum. Here, an analysis of rhetorical arete and virtus in the postIdes correspondence reveals how Cicero, through a campaign of calculated self-fashioning, tightly bound the welfare of the state to his own persona and in turn won recognition as the helmsman of the Republic after Caesar's assassination.

The rhetorical qualities of Latin epistolography have long been recognized by both ancient and modern commentators alike. In particular, it is the letter's capacity to reflect the selfconscious character of its writer which has become a renewed topic of interest in recent years. This assessment of ethos in Cicero's post-Ides correspondence ultimately elaborates on fundamental work done by modern scholars on epistolary persuasion among the Roman elite and illuminates the nuanced, critical, and underappreciated role that the letters played in his cultivation of fresh authority following Caesar's assassination. 


\section{Bibliography}

Adkins, Arthur W.H. Merit and Responsibility, A Study in Greek Values (Oxfordshire: Clarendon Press) 1960.

Allard-Nelson, Susan K. 'Virtue in Aristotle's Rhetoric: A Metaphysical and Ethical Capacity' in Philosophy and Rhetoric (Vol. 34. No. 3.) 2001; 245-259.

Allen, Walter. 'Cicero's Conceit' in Transactions and Proceedings of the American Philological Association (Vol. 85) 1954; 121-144.

Ando, Clifford. 'Ex Imperio Libertas: Freedom and Republican Empire' in Catalina Balmaceda (ed.) Libertas and Res Publics in the Roman Republic (Leiden: Brill) 2020; 104-117.

Arena, Valentina. Libertas and the Practice of Politics in the Late Roman Republic (Cambridge: Cambridge University Press) 2012.

'The God Liber and Republican Notions of Libertas in the Late Roman Republic' in Catalina Balmaceda (ed.) Libertas and Res Publics in the Roman Republic (Leiden: Brill) $2020 ; 55-83$

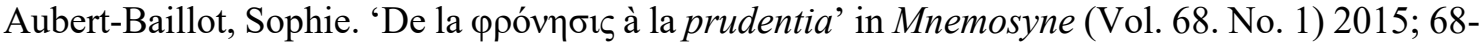
90.

Austin, Norman. 'The Function of Digressions in the Iliad' in Greek, Roman, and Byzantine Studies (Vol. 7. No. 4) 2003; 295-312.

Ball, Terence. Reappraising Political Theory: Revisionist Studies in the History of Political Thought (Oxford: Oxford University Press) 1995.

Balmaceda, Catalina. Virtus Romana: Politics and Morality in the Roman Historians (Chapel Hill: University of North Carolina Press) 2017.

'Libertas in Early Latin Authors' in Catalina Balmaceda (ed.) Libertas and Res Publica in the Roman Republic (Leiden: Brill) 2020; 33-54.

Baraz, Yelena. A Written Republic: Cicero's Philosophical Politics (Princeton \& Oxford: Princeton University Press) 2012.

Barnes, Jonathan. 'Roman Aristotle' in J. Barnes and M. Griffin (eds.) Philosophia II: Plato and Aristotle at Rome (Oxford: Oxford University Press) 1997; 1-69.

Bernard, J.-E. La sociabilité épistolaire chez Cicéron (Paris: Honoré Champion) 2013.

Berry, D. H. Cicero's Catilinarians (Oxford: Oxford University Press) 2020.

Blom, Henriette van der. 'Officium and res publica: Cicero's Political Role after the Ides of March' in Classica et Mediaevalia (Vo. 54) 2003; 287-319.

Cicero's Role Models: The Political Strategy of a Newcomer (Oxford: Oxford University Press) 2010.

Oratory and Political Career in the Late Roman Republic (Cambridge: Cambridge University Press) 2016. 
Brewer, Talbot. 'Virtues We Can Share: Friendship and Aristotelian Ethical Theory' in Ethics (Vol. 115. No. 4) 2005; 721-758.

Brunt, P. A. 'Cicero's Officium in the Civil War' in The Journal of Roman Studies (Vol. 76) 1986; 12-32.

The Fall of the Roman Republic and Related Essays (Oxford: Oxford University Press) 1988.

Bryant, Joseph M. Moral Codes and Social Structure in Ancient Greece: A Sociology of Greek Ethics from Homer to the Epicureans and Stoics (New York: State University of New York Press) 1996.

Burnand, Christopher John. Roman Representations of the Orator during the Last Century of the Republic (DPhil diss. Oxford University) 2000.

Butler, Shane. The Hand of Cicero (New York: Routledge) 2002.

Cape, Robert W. 'Cicero's Consular Speeches' in James M. May (ed.) Brill's Companion to Cicero. Oratory and Rhetoric (Leiden: Brill) 2002; 113-158.

Caplan, Harry (trans.) [Cicero]. Rhetorica ad Herennium (Cambridge, MA: Harvard University Press) 1954.

Cary, Earnest (trans.) Dio Cassius. Roman History, Volume III: Books 36-40 (Cambridge, MA: Harvard University) 1914.

Cherry, Roger D. 'Ethos Versus Persona: Self-Representation in Written Discourse' in Written Communication (Vol. 15. No. 3.) 1988; 384-410.

Christian, Emily. 'A Philosophy of Legitimacy in Cicero's Philippics' in Tom Stevenson and Marcus Wilson (eds.) Cicero's Philippics: History, Rhetoric, and Ideology (Auckland: Auckland University Press) 2008; 153-167.

Clarke, M. The Noblest Roman: Marcus Brutus and His Reputation (Cornell: Cornell University Press) 1981.

Cokayne, Karen. Experiencing Old Age in Ancient Rome (London \& New York: Routledge) 2003.

Cotton, Charles (trans.) Michel de Montaigne. Essais, Book 1. Edited by William C. Hazlitt (London: s.n) 1887.

Cotton, Hannah M. 'The Role of Cicero's Letters of Recommendation: Iustitia versus Gratia?' in Hermes (Vol. 114. No. 4) 1986; 443-460.

Cowan, Eleanor. 'Libertas in the Philippics' in Tom Stevenson and Marcus Wilson (eds.) Cicero's Philippics: History, Rhetoric, and Ideology (Auckland: Auckland University Press) 2008; 140-152.

Craig, Christopher. 'Audience Expectations, Invective, and Proof' in Jonathan Powell and Jeremy Paterson (eds.) Cicero the Advocate (Oxford: Oxford University Press) 2004; 188-214.

Dickson, Keith. Nestor: Poetic Memory in Greek Epic (New York \& London: Garland Publishing, Inc.) 1995. 
Dodds, Eric R. The Greeks and the Irrational (Berkley: University of California Press) 1951.

Dominik, W. and Jon Hall (eds.) A Companion to Roman Rhetoric (Oxford: Blackwell Publishing) 2007.

Dugan, John. Making a New Man: Ciceronian Self-Fashioning in the Rhetorical Works (Oxford: Oxford University Press) 2005.

'Cicero's Rhetorical Theory' in Catherine Steel (ed.) The Cambridge Companion to Cicero (Cambridge: Cambridge University Press) 2013; 25-40.

Dunkle, J. Roger. 'The Greek Tyrant and Roman Political Invective of the Late Republic' in Transactions of the American Philological Association (Vol. 98) 1967; 151-171.

Earl, D. The Moral and Political Tradition of Rome (London: Thames \& Hudson) 1967.

The Political Thought of Sallust (Cambridge: Cambridge University Press) 1961.

Edwards, Catharine. The Politics of Immorality in Ancient Rome (Cambridge: Cambridge University Press) 1993.

Enos, R. \& McClaran, J. 'Audience and Image in Ciceronian Rome: Creation and Constraints of the vir bonus Personality' in Central States Speech Journal (Vol. 29) 1978; 98-106.

Epstein, David. Personal Enmity in Roman Politics, 218-43 BC (London \& New York: Croon Helm) 1987.

Fagles, Robert (trans.) Homer. Iliad (New York: Penguin) 1998.

Falconer, W. A. (trans.) Cicero. On Old Age. On Friendship. On Divination (Cambridge, MA: Harvard University Press) 1923.

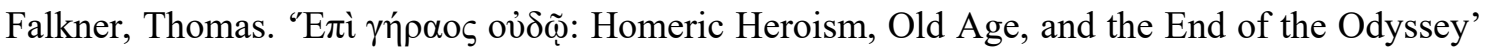
in T. Falkner and J. de Luce (eds.) Old Age in Greek and Latin Literature (Albany: State University of New York Press) 1989; 21-67.

Fantham, Elaine. The Roman World of Cicero's De Oratore (Oxford: Oxford University Press) 2004.

Finkelberg, Margalit. 'Odysseus and the Genus Hero' in Greece \& Rome (Vol. 42. No. 1) 1995; $1-14$.

'Timē and Aretē in Homer' in The Classical Quarterly (Vol. 48. No. 1) 1998; 14-28.

'Virtue and Circumstances: On the City-State Concept of Arete' in The American Journal of Philology (Vol. 123. No. 1) 2002; 35-49.

Flower, Harriet. Ancestor Masks and Aristocratic Power in Roman Culture (Oxford: Oxford University Press) 1996.

'Elite Self-Representation in Rome' in Michael Peachin (ed.) The Oxford Handbook of Social Relations in the Roman World (Oxford: Oxford University Press) 2011; 271-282.

Fortenbaugh, William W. Aristotle on Emotion (London: Duckworth) 1975. 
'Benevolentiam conciliare and animos permovere: Some remarks on Cicero's De oratore 2.178-216' in Rhetorica: A Journal of the History of Rhetoric (Vol. 6. No. 3) $1988 ; 259-273$.

and Peter Steinmetz (eds.) Cicero's Knowledge of the Peripatos (New Jersey:

Transaction Publishers) 1989.

'Aristotle on Persuasion Through Character' in Rhetorica: A Journal of the History of Rhetoric (Vol. 10. No. 3) 1992; 207-244.

Freese, J. H. (trans.) Aristotle. Art of Rhetoric. Revised by Gisela Striker (Cambridge, MA: Harvard University Press) 2020.

Fowler, Harold N. (trans.) Plutarch. Moralia, Volume. X (Cambridge, MA: Harvard University Press) 1936.

Frisch, Hartvig. Cicero's Fight for the Republic: The Historical Background of Cicero's Philippics (Copenhagen: Gylendal) 1946.

Fulkerson, Laurel. 'Cicero's Palinode: Inconsistency in the Late Republic' in Greece and Rome (Vol. 60. No. 2) 2013; 246-261.

Garver, Eugene. Aristotle's Rhetoric: An Art of Character (Chicago and London: University of Chicago Press) 1994.

Gildenhard, Ingo. 'A Republic in Letters' in Letters and Communities: Studies in the SocioPolitical Dimensions of Ancient Epistolography (New York: Oxford University Press) 2018; 205-233.

Gill, Christopher. The Structured Self in Hellenistic and Roman Thought (Oxford: Oxford University Press) 2006.

Grabarek, Gabriel P. Men of Letters: The Oratorical and Philosophical Relationship between Cicero and Brutus (PhD diss. Indiana University) 2010.

Griffin, Jasper. Homer on Life and Death (Oxford: Clarendon Press) 1980.

Grimaldi, William M.A. Aristotle, Rhetoric: A Commentary (New York: Fordham University Press) 1980.

Gunderson, Erik. Staging Masculinity: The Rhetoric of Performance in the Roman World (Michigan: University of Michigan Press) 2000.

Habicht, C. Cicero the Politician (Baltimore: Johns Hopkins University Press) 1990.

Hall, Jon. 'The Philippics' in James M. May (ed.) Brill's Companion to Cicero. Oratory and Rhetoric (Leiden: Brill) 2002; 273-304.

Politeness and Politics in Cicero's Letters (Oxford: Oxford University Press) 2009.

'Serving the Times: Cicero and Caesar the Dictator' in William J. Dominik, John Garthwaite, and Paul Roche (eds.) Writing and Politics in Imperial Rome (Boston: Brill) 2009; 89-110. 
'Saviour of the Republic and Father of the Fatherland: Cicero and Political Crisis' in Catherine Steel (ed.) The Cambridge Companion to Cicero (Cambridge: Cambridge University Press) 2013; 215-230.

Hanchey, Dan. 'Otium as Civic and Personal Stability in Cicero's Dialogues' in Classical World (Vol. 106. No. 2) 2013; 171-197.

Hariman, Robert. 'Political Style in Cicero's Letters to Atticus' in Rhetorica: A Journal History of Rhetoric (Vol. 7. No. 2.) 1989; 145-158.

Harlow, Mary and Ray Laurence. Growing Up and Growing old in Ancient Rome: A Life Course Approach (London \& New York: Routledge) 2002.

Hawhee, Debra. 'Agonism and Arete' in Philosophy and Rhetoric (Vol. 35. No. 3) 2002; 185207.

Heinze, R. 'Auctoritas' in Hermes (Vol. 60) 1925; 348-366.

Hellegouarc'h, Joseph. Le Vocabulaire Latin: Des Relations et des Partis Politiques sous la République (Paris: Les Belles Lettres) 1963.

Hodgson, Louise. Res Publica and the Roman Republic: 'Without Body or Form' (Oxford: Oxford University Press) 2017.

Hölkeskamp, Karl-Joachim. Rekonstruktionen einer Republik: Die politische Kultur des antiken Rom und die Forschung der letzten Jahrzehnte (Munich: De Gruyter Oldenbourg) 2004.

- Die Entstehung der Nobilität: Studien zur sozialen und politischen Geschichte der römischen Republik im 4. Jh. v. Chr. (Stuttgart: Franz Steiner Verlag) 2011.

'Friends, Romans, Countrymen: Addressing the Roman People and the Rhetoric of Inclusion' in Catherine Steel and Henriette van der Blom (eds.) Community and Communication. Oratory and Politics in Republican Rome (Oxford: Oxford University Press) 2013; 12-28.

Horner, Anne Elizabeth. Ancient Values: Aretē and Virtus (PhD diss. University of Virginia) 1975.

Hourcade, Annie. 'La bienveillance dans la problématique du conseil chez Aristote' in Phoenix (Vol. 72. Nos. 1/2) 2018; 86-104.

Hutchinson, G.O. Cicero's Correspondence: A Literary Study (Oxford: Oxford University Press) 1998.

Huzar, Eleanor G. Mark Antony: A Biography (Minneapolis: University of Minnesota Press) 1978.

Kennedy, George A. The Art of Persuasion in Greece (Princeton: Princeton University Press) 1963.

'Antony's Speech at Caesar's Funeral' in QJS (Vol. 54) 1968; 99-106.

- The Art of Rhetoric in the Roman World, 300 BC-AD 300 (Princeton: Princeton University Press) 1972. 
Kenty, Joanna. Cicero's Political Personae (Cambridge: Cambridge University Press) 2020.

Knight, Donald W. 'The Political Acumen of Cicero after the Death of Caesar' in Latomus (Vol. 27. No. 1) 1968; 157-164.

Konstan, David. Friendship in the Classical World (Cambridge: Cambridge University Press) 1997.

Lamb, W. R. M. (trans.) Plato. Laches. Protagoras. Meno. Euthydemus (Cambridge, MA: Harvard University Press) 1924.

Lämmle, Cédric Scheidegger. 'Last Words: Cicero's Late Works and the Poetics of a Literary Legacy' in Andreas Gavrielatos (ed.) Self-Presentation and Identity in the Roman World (Newcastle upon Tyne: Cambridge Scholars Publishing) 2017; 17-36.

Leach, Eleanor W. 'An gravius aliquid scribam: Roman Seniores Write to Iuvenes' in Transactions of the American Philological Association (Vol. 36. No. 2) 2006; 247-267.

Leber, Nathan. Depictions of Cassius and Brutus in the Correspondence of Cicero ( $\mathrm{PhD}$ diss. University of Western Australia) 2015.

Lessie, Alexander. Becoming Mark Antony: A Metabiographical Study of Characterization and Reception (PhD diss. University of California) 2015.

Lewis, Sian (ed.) Ancient Tyranny (Edinburgh: Edinburgh University Press) 2006.

Lintott, Andrew W. Cicero as Evidence: A Historian's Companion (Oxford: Oxford University Press) 2008.

'The Assassination' in Miriam Griffin (ed.) A Companion to Julius Caesar (Oxford: Wiley-Blackwell) 2009; 72-82.

Loney, Alexander C. 'Odysseus' Terrifying Revenge' in The Ethics of Revenge and the Meanings of the Odyssey (Oxford: Oxford University Press) 2019; 119-170.

Macdonald, C (trans.) Cicero. In Catilinam 1-4. Pro Sulla. Pro Flacco (Cambridge MA: Harvard University Press) 1976.

Malherbe, Abraham J. Ancient Epistolary Theorists (Atlanta, G.A: Scholars Press) 1988.

Malcovati, Henrica (ed.) Oratorum Romanorum Fragmenta Liberae Rei Publicae Iteratis Curis 2nd edition (Taurinorum: In Aedibus Io. Bapt. Paraviae) 1955.

Martin, Richard P. The Language of Heroes: Speech and Performance in the Iliad (Ithaca \& London: Cornell University Press) 1989.

May, James M. Trials of Character: The Eloquence of Ciceronian Ethos (Chapel Hill: University of North Carolina Press) 1988. 'Cicero and the Beasts' in Syllecta Classica (Vol. 7) 1996; 143-153.

McClintock, Richard C. Cicero's Narrative Technique in the Judicial Speeches ( $\mathrm{PhD}$ diss. University of North Carolina) 1975. 
McConnell, Sean. Philosophical Life in Cicero's Letters (Cambridge: Cambridge University Press) 2014.

McDonnell, Myles. 'Roman Men and Greek Virtue' in R. Rosen and I. Sluiter (eds.) Andreia: Studies in Manliness and Courage in Classical Antiquity (Leiden \& Boston: Brill) 2003; 235-261.

Meyer, Elizabeth A. Epistolary Ethos: A Rhetorical Analysis of Cicero's Letters (PhD diss. Boston University) 2000.

Miles, Geoffrey. Shakespeare and the Constant Romans (Oxford: Clarendon) 1996.

Miller, Walter (trans.) Cicero. On Duties (Cambridge, MA: Harvard University Press) 1913.

Mitchell, Hannah. 'The Reputation of L. Munatius Plancus and the Idea of Serving the Times' in Kit Morrell, Josiah Osgood, and Kathryn Welch (eds.) The Alternative Augustan Age (New York: Oxford University Press) 2019; 164-181.

Mitchell, Thomas N. Cicero: The Senior Statesman (New Haven, Connecticut: Yale University Press) 1991.

Morello, Ruth and A. D. Morrison (eds.) Ancient Letters: Classical and Late Antique Epistolography (Oxford: Oxford University Press) 2007.

Morello, Ruth. 'Writer and Addressee in Cicero's Letters' in Catherine Steel (ed) The Cambridge Companion to Cicero (Cambridge: Cambridge University Press) 2013; 196-214.

Morstein-Marx, Robert. Mass Oratory and Political Power in the Late Roman Republic (Cambridge: Cambridge University Press) 2004.

Mortensen, Daniel. Wine, Drunkenness, and the Rhetoric of Crisis in Ancient Rome (PhD diss. University of Wisconsin-Madison) 1999.

Nagy, Gregory. The Best of the Achaeans: Concepts of the Hero in Archaic Greek Poetry (Baltimore: Johns Hopkins University Press) 1979.

Nisbet, R. G. M. and M. Hubbard. A Commentary on Horace: Odes Book 1 (London, Clarendon Press: Oxford University Press) 1970.

Parkin, Tim G. Old Age in the Roman World: A Social and Cultural History (Baltimore: Johns Hopkins University Press) 2002.

Poster, Carol. 'Introduction' in Linda Mitchell (ed) Letter-writing Manual and Instruction from Antiquity to the Present: Historical and Bibliographic Studies (Columbia, S.C: University of South Carolina Press) 2007; 1-6.

Powell, Jonathan G. F. Cicero. Cato Maior De Senectute. Cambridge Classical Commentaries (Cambridge: Cambridge University Press) 1988.

Purves, Alex C. 'Wind and Time in Homeric Epic' in Transactions of the American Philological Association (Vol. 140. No. 2) 2010; 323-350.

Rackham, H. (trans.) Aristotle. Nicomachean Ethics (Cambridge, MA: Harvard University Press) 1926. 
Ramsey, John T. 'The Senate, Mark Antony, and Caesar's Legislative Legacy' in The Classical Quarterly (Vol. 44) 1994; 130-145.

Rawson, Elizabeth. Intellectual Life in the Late Roman Republic (Baltimore: John Hopkins University Press) 1985.

'The Aftermath of the Ides' in J. A. Crook, Andrew Lintott, Elizabeth Rawson (eds.) The Cambridge Ancient History, Volume IX (Cambridge: University of Cambridge Press) 1994; 468-490.

Reeve, C. D. C. Practices of Reason: Aristotle's Nicomachean Ethics (Oxford: Oxford University Press) 1995.

Roberts, W. Rhys. (trans.) Demetrius. On Style. Revised by Doreen Innes (Cambridge, MA: Harvard University Press) 1995.

Roisman, Hanna M. 'Nestor the Good Counsellor' in The Classical Quarterly (Vol. 55. No.1) $2005 ; 17-38$.

Rolfe, J.C. (trans.) Cornelius Nepos. On Great Generals. On Historians (Cambridge, MA: Harvard University Press) 1929.

Romilly, Jacqueline de. 'Eunoia in Isocrates or The Political Importance of Creating Good Will' in Journal of Hellenic Studies (Vol. 78) 1958; 92-101.

Rorty, Améle. 'Aristotle on the Virtues of Rhetoric' in The Review of Metaphysics (Vol. 64. No. 4) $2011 ; 715-733$.

Saller, Richard. 'Familia, Domus, and the Roman Conception of the Family' in Phoenix (Vol. 38. No. 4) 1984 ; 336-355.

Samponaro, Laura M. Style and Character in Ciceronian Oratory (PhD diss. Columbia University) 2007.

Santangelo, Federico. Divination, Prediction, and the End of the Roman Republic (Cambridge: Cambridge University Press) 2013.

Sattler, W. M. 'Conceptions of Ethos in Rhetoric' in Speech Monographs (Vol. 14) 1947; 55-65.

Schütrumpf, Eckart. 'Ethos in Persuasion and in Musical Education in Plato and Aristotle' in David C. Mirhady (ed.) Influences on Peripatetic Rhetoric: Essays in Honour of William W. Fortenbaugh (Leiden \& Boston: Brill) 2007; 37-52.

Shackleton Bailey, D. R. Cicero (London: Duckworth) 1971.

(trans.) Cicero. Letters to Atticus, Volume IV (Cambridge, MA: Harvard University Press) 1999.

(trans.) Cicero. Letters to Friends, Volume II: Letters 114-280 (Cambridge, MA: Harvard University Press) 2001.

(trans.) Cicero. Letters to Friends, Volume III: Letters 281-435 (Cambridge, MA: Harvard University Press) 2001. 
- (trans.) Cicero. Letters to Quintus and Brutus. Letter Fragments. Letter to Octavian. Invectives. Handbook of Electioneering (Cambridge, MA: Harvard University Press) 2002.

-(trans.) Cicero. Philippics 1-6. Revised by John T. Ramsey \& Gesine Manuwald (Cambridge, MA: Harvard University Press) 2010.

Smith, Nicholas. 'Some Thoughts about the Origins of Greek Ethics' in The Journal of Ethics (Vol. 5. No. 1) 2001; 3-20.

Sogno, Cristiana. 'The Ghost of Cicero's Letters: Epistolography and Historiography in Senatorial Letter-Writing' in The Journal of Late Antiquity (Vol. 7. No. 2) 2014; 201222.

Solmsen, Friedrich. 'Aristotle and the Orator's Playing upon the Feelings' in Classical Philology (Vol. 33 No. 4) 1938; 390-404.

'The Aristotelian Tradition in Ancient Rhetoric' in The American Journal of Philology (Vol. 62. No. 2) 1941; 169-190.

Stanley, Keith. The Shield of Homer: Narrative Structure in the Iliad (Princeton: Princeton University Press) 1993.

Stevenson, Tom. 'Tyrants, kings, and fathers in the Philippics' in Tom Stevenson and Marcus Wilson (eds.) Cicero's Philippics: History, Rhetoric, and Ideology (Auckland: Auckland University Press) 2008; 95-113.

'Antony as Tyrant in Cicero's First Philippic' in Ramus (Vol. 38. No. 2) 2009; 174186.

Stockton, David. Cicero: A Political Biography (Oxford: Oxford University Press) 1971.

Suder, Wieslaw. 'On Age Classification in Roman Imperial Literature' in The Classical Bulletin (Vol. 55) 1978; 5-9.

Sumi, Geoffrey S. Ceremony and Power: Performing Politics in Rome between Republic and Empire (Ann Arbor: University of Michigan Press) 2005.

Sutton, E. W. and H. Rackham (trans.) Cicero. On the Orator: Books 1-2 (Cambridge, MA: Harvard University Press) 1942.

Syme, Ronald. The Roman Revolution (Oxford: Oxford University Press) 1939.

'Cicero's Change of Plan (August 7, 44 BC)' in Federico Santangelo (ed.) Approaching the Roman Revolution: Papers on Republican History (Oxford: Oxford University Press) 2016; 196-205.

Tatum, W. Jeffrey. Always I Am Caesar (Oxford: Blackwell Publishing) 2008.

'The Practice of Politics and the Unpredictable Dynamics of Clout in the Roman Republic' in Dean Hammer (ed.) A Companion to Greek Democracy and the Roman Republic (Oxford: Wiley-Blackwell Publishing) 2015; 257-274.

Quintus Cicero: A Brief Handbook on Canvassing for Office (Commentariolum Petitionis) (Oxford: Oxford University Press) 2018. 
'A Great and Arduous Struggle: Marcus Antonius and the Rhetoric of Libertas in 44-43 $\mathrm{BC}$ ' in Catalina Balmaceda (ed.) Libertas and Res Publics in the Roman Republic (Leiden: Brill) 2020; 189-215.

Taylor, C.C.W. 'Phronesis' in (ed.) T. Honderich The Oxford Companion to Philosophy (Oxford: Oxford University Press) 2005.

Taylor, Lily Ross. Party Politics in the Age of Caesar (California: University of California Press) 1949.

Tempest, Kathryn. Cicero: Politics and Persuasion in Ancient Rome (London: Bloomsbury) 2014.

Tracy, Catherine. 'Cicero's Constantia in Theory and Practice' in Walter Nicgorski (ed.) Cicero 's Practical Philosophy (Indiana: University of Notre Dame Press) 2012; 79-112.

Treggiari, Susan. 'Ancestral Virtues and Vices: Cicero on Nature, Nurture, and Presentation' in D. Braund and C. Gill (eds.) Myth, History, and Culture in Republican Rome. Studies in Honour of T. P. Wiseman (Exeter: Exeter University Publishing) 2003; 139-164.

Tyrrell, Robert Y. and Louis C. Purser. The Correspondence of M. Tullius Cicero, Volume VI (Dublin: Hodges, Figgis \& Co.) 1899.

Vasaly, Ann. 'The Political Impact of Cicero's Speeches' in Catherine Steel (ed.) The Cambridge Companion to Cicero (Cambridge: Cambridge University Press) 2013; 141-159.

Verboven, Koenraad. 'Friendship Among in the Romans' in Michael Peachin (ed) The Oxford Handbook of Social Relations in the Roman World (Oxford: Oxford University Press) 2011; 404-419.

Warmington, E.H. (trans.) Remains of Old Latin, Volume IV: Archaic Inscriptions (Cambridge, MA: Harvard University Press) 1940.

Watkins, Thomas H. L. Munatius Plancus: Serving and Surviving in the Roman Revolution, Second Addition (New York: Routledge) 2019.

Watts, N. H. (trans.) Cicero. Pro Archia. Post Reditum in Senatu. Post Reditum ad Quirites. De Domo Sua. De Haruspicum Responsis. Pro Plancio (Cambridge, MA: Harvard University Press) 1923.

Welch, Kathryn. 'Nimium Felix: Caesar's Felicitas and Cicero's Philippics' in Tom Stevenson and Marcus Wilson (eds.) Cicero's Philippics: History, Rhetoric, and Ideology (Auckland: Auckland University Press) 2008; 181-213.

- Magnus Pius: Sextus Pompeius and the Transformation of the Roman Republic (Swansea: The Classical Press of Wales) 2012.

White, Peter. Cicero in Letters: Epistolary Relations of the Late Republic (Oxford: Oxford University Press) 2010.

'Senatorial Epistolography from Cicero to Sidonius: Emergence of a Genre' in Bulletin of the Institute of Classical Studies of the University of London (Vol. 61. No. 2) 2018; 721. 
Wilcox, Amanda. The Gift of Correspondence in Classical Rome: Friendship in Cicero's Ad Familiares and Seneca's Moral Epistles (Wisconsin: University of Wisconsin Press) 2012.

Wisse, Jakob. Ethos and Pathos from Aristotle to Cicero (Amsterdam: Adolf M. Hakkert Publishing) 1989.

Wooten, Cecil W. Cicero's Philippics and their Demosthenic Model: The Rhetoric of Crisis (Chapel Hill: University of North Carolina Press) 1983.

Zarecki, Jonathan. Cicero's Ideal Statesman in Theory and Practice (London: Bloomsbury) 2014. 